http://dx.doi.org/10.11646/zoosymposia.13.1.20

http://zoobank.org/urn:lsid:zoobank.org:pub:197DFF61-4287-4263-867E-3798B556052F

\title{
New taxa and new synonymy in Muricidae (Neogastropoda: Pagodulinae, Trophoninae, Ocenebrinae) from the Northeast Pacific
}

\author{
ROLAND HOUART ${ }^{1}$, GEERAT VERMEIJ ${ }^{2} \&$ SHAWN WIEDRICK ${ }^{3}$ \\ ${ }^{l}$ Research Associate, Institut royal des Sciences naturelles de Belgique, Brussels, Belgium, and Muséum national d'Histoire naturelle, \\ Paris, France.E-mail: roland.houart@skynet.be \\ ${ }^{2}$ Department of Earth and Planetary Sciences, University of California at Davis, Davis, CA 95616, USA. E-mail: \\ gjvermeij@ucdavis.edu \\ ${ }^{3}$ Department of Invertebrate Paleontology, Natural History Museum of Los Angeles County, 900 Exposition Blvd, Los Angeles, CA \\ 90007, USA. E-mail: shawnwiedrick@hotmail.com
}

\begin{abstract}
The results of an extensive examination of northeast Pacific muricid gastropods ranging from Aleutian Islands, Alaska, to mid-Baja California, is presented. Two new genera and 26 new species are described:

In Pagodulinae: Abyssotrophon fusiformis n. sp., A. newmani n. sp., Boreotrophon cascadiensis n. sp., B. cordellensis n. sp., B. cortesianus n. sp., B. obesus n. sp., B. subapolyonis n. sp., B. vancouverensis n. sp., B. aleuticus n. sp., B. pseudotripherus n. sp., B. santarosensis n. sp., B. tannerensis n. sp.

In Trophoninae: Warenia, n. gen., Scabrotrophon buldirensis n. sp, S. kantori n. sp., S. lima n. sp., S. macleani n. sp., S. moresbyensis n. sp., S. norafosterae n. sp., S. trifidus n. sp., Nipponotrophon exquisitus n. sp.

In Ocenebrinae: Paciocinebrina n. gen., Nucella angustior n. sp., Paciocinebrina benitoensis n. sp., P. macleani n. sp., P. neobarbarensis n. sp., P. pseudomunda n. sp., P. thelmacrowae n. sp.

New synonymy: Boreotrophon kamchatkanus Dall, 1902 (+ Trophonopsis nanus Ergorov, 1994); Paciocinebrina atropurpurea (Carpenter, 1865) (+ Tritonalia interfossa var. clathrata Dall, 1919, Ocinebra rubra Baker, 1891, Tritonalia tracheia Dall, 1919); P. barbarensis (Gabb, 1865) (+ Tritonalia interfossa var. beta Dall, 1919, Ocenebra keenae Bormann, 1946); P. circumtexta (Stearns, 1871) (+ Ocinebra circumtexta var. aurantia Stearns, 1895, Tritonalia circumtexta var. citrica Dall, 1919, Tritonalia lurida var. rotunda Dall, 1919); P. foveolata (Hinds, 1844) (+Tritonalia epiphanea Dall, 1919, Tritonalia fusconotata Dall, 1919); P. gracillima (Stearns, 1871) (+ Tritonalia gracillima var. obesa Dall, 1919, Ocinebra stearnsi Hemphill, 1911); P. interfossa (Carpenter, 1864) (+ Tritonalia interfossa alpha Dall, 1921); P. lurida (Middendorff, 1848) (+ Vitularia aspera Baird, 1863), P. sclera (Dall, 1919) (+ Coralliophila (Pseudomurex) kincaidi Dall, 1919).

Generic assignments are changed for the following taxa: Boreotrophon kamchatkanus Dall, 1902; Warenia elegantula (Dall, 1907); Scabrotrophon stuarti (E.A. Smith, 1880); Paciocinebrina atropurpurea (Carpenter, 1865), P. barbarensis (Gabb, 1865), P. circumtexta (Stearns, 1871), P. crispatissima (Berry, 1953), P. foveolata (Hinds, 1844), $P$. fraseri (Oldroyd, 1920), P. gracillima (Stearns, 1871), P. grippi (Dall, 1911), P. interfossa (Carpenter, 1864), P. lurida (Middendorff, 1848), P. minor (Dall, 1919), P. munda (Carpenter, 1864), P. seftoni (Chace, 1958), P. sclera (Dall, 1919). Boreotrophon alborostratus Taki, 1938, is reinstated. Abyssotrophon Egorov, 1993 and Nodulotrophon Habe \& Ito, 1965 are here assigned to Pagodulinae Barco et al., 2012, based on radula morphology.
\end{abstract}

Keywords: New genera, new species, new synonymy, Trophoninae, Pagodulinae, Ocenebrinae, northeast Pacific

\section{Introduction}

The family Muricidae comprises predatory neogastropods that feed either by drilling hard-shelled prey or by parasitizing various animals, including corals. As one of the largest gastropod families, Muricidae has been extensively documented by taxonomists for centuries and work has continued to the present day, with newly described species added annually, both in Recent and fossil assemblages. 
This paper is the latest in a long line of contributions on the muricid fauna of the temperate northeast Pacific, an area of coastline from western Alaska to central Baja California. The northeast Pacific is one of several biogeographical regions from which Linnaeus named no species. Gmelin (1791) was the first to name muricids from the area, which are now known as Ceratostoma foliatum (Gmelin, 1791), Nucella lamellosa (Gmelin, 1791), and N. lima (Gmelin, 1791), all named on the basis of Alaskan material. Although most of the shallow-water species were described in the nineteenth century, it is notable that surprises have continued to surface, including several intertidal species described in the present paper. Knowledge of the deep-water muricids lagged behind that of the shallow-water taxa, with Dall $(1891,1902)$ and McLean (1996) making the largest contributions. The present paper adds substantially to the inventory of deep-water muricids.

Biogeography of northeast Pacific Muricidae. No gastropod family has a greater bathymetric range or wider geographical distribution than the Muricidae. Species are known from the upper intertidal zone (including such genera as Acanthinucella, Mexacanthina, Muricodrupa, Nucella, Plicopurpura and Purpura) to depths greater than $7 \mathrm{~km}$ in the hadal zone of the northwest Pacific, as in Abyssotrophon hadalis (Sysoev, 1992). Although the Muricidae are like most other large marine clades in reaching peak diversity in the tropics, especially the Indo-Malayan part of the Indo-West Pacific, they are also well-represented in temperate waters and even in polar seas. Among geographical regions outside the tropics, the northeast Pacific, with some 100 species, ranks as one of the most diverse for Muricidae.

The muricid fauna of the northeast Pacific is numerically dominated by four clades: Pagodulinae, Trophoninae, and two clades of Ocenebrinae, clades A and B of Barco et al. (2017). Five additional clades Coralliophilinae, Ergalataxinae, Muricopsinae, Rapaninae, and clade D of Ocenebrinae - are represented by one or two species each. Five major muricid clades do not occur at all in the temperate northeast Pacific: Aspellinae, Haustrinae, Muricinae, Typhinae, and clade C (Eupleura) of Ocenebrinae (for phylogenies see Barco et al. 2010, 2012, 2015, 2017). All five clades except the south-temperate Haustrinae are known from tropical to subtropical parts of the eastern Pacific.

Within the northeast Pacific, clade A of Ocenebrinae (with such genera as Acanthinucella, Austrotrophon, Forreria and Roperia) is restricted to the warmer parts from central California south. The other diverse clades extend into the cool-temperate and subarctic North Pacific, as in Boreotrophon (Pagodulinae), Nucella and Ceratostoma (Clade B of Ocenebrinae), and Nipponotrophon (Trophoninae). Phylogenetic and palaeontological evidence indicates that the large northeast Pacific clades came to the region with different origins and at different times. The Pagodulinae apparently originated in the southern hemisphere (Barco et al. 2012) and likely extended to the northeast Pacific through the deep sea, becoming shallow-water only in the far north.

The time of arrival of this clade in the northeast Pacific remains unclear because fossil species have not been critically re-examined in the light of recent phylogenetic evidence, but taxa that could belong to this clade are known from the Late Eocene in the Keasey Formation of Oregon (Hickman 1980: Trophonopsis platacantha Hickman, 1980). Trophoninae also likely originated in the cool southern hemisphere, and like Pagodulinae probably entered the region in deep water, perhaps by the Miocene.

Clade A of Ocenebrinae is known from the northeast Pacific since the late Oligocene (Vermeij 2001) and in the southeast Pacific (as Acanthina) by the latest Oligocene (DeVries 2003). If the fossil genus Spinucella belongs to this clade, as seems likely (Vermeij 2001), it also occurred in the southeast and northeast temperate Atlantic. Although the place of origin of the clade remains uncertain - either the southeast or northeast Pacific according to fossil evidence - the route of dispersal in the Pacific was almost certainly through shallow waters. Clade B of Ocenebrinae seems to have had a tropical origin (Amano \& Vermeij 1998), with the earliest members assigned to Ceratostoma and the fossil genus Pterorytis (Vermeij \& Vokes 1997). The late Oligocene Californian species Thais packi Clark, 1918, was assigned by Vermeij (2001) to Nucella, but the presence of a labral tooth is also consistent with assignment to a genus in Clade A. In any case, one or more lineages in clade B adapted to cold waters in the North Pacific during the Miocene before spreading to the northwest Pacific and, in the case of Nucella, to the Atlantic. As in clade A, dispersal in clade B occurred in shallow water.

It is curious that members of clade B are not present in the cool Southeast Pacific, where members of clade A (Acanthina, Chorus, Crassilabrum and Xanthochorus, with additional fossil genera) and Rapaninae (Concholepas and a temperate lineage of Stramonita) predominate in shallow water.

Six clades of endemic temperate muricid lineages are very poorly or not at all represented in the northeast Pacific. Clade D of Ocenebrinae is a chiefly Atlantic clade that perhaps reached the northeast Pacific only as 
one or two species of Urosalpinx [U. subangulata (Stearns, 1871)]. When this dispersal took place is unknown, but clade D did not diversify anywhere in the North Pacific. The Haustrinae are known only in the southern hemisphere. The Coralliophilinae are nearly all tropical except for one Californian species and several species in southern Africa and Australasia. Temperate Muricopsinae occur in Australasia and southern Africa, and as one species of Maxwellia in the northeast Pacific. The Rapaninae have diversified in Australasia, southern South America, and with two independent lineages (Rapana and Reishia) in northeast Asia and as one species of Reishia in southern Africa; but only one species extends into the southern part of the temperate northeast Pacific from the tropical eastern Pacific (see Claremont et al. 2013). Finally, the Typhinae occur in relatively deep waters in temperate Australia, New Zealand, southern Africa and Japan, but none extends to the colder portions of these regions or anywhere in the temperate northeast Pacific or cooler North Atlantic.

In summary, the northeast Pacific muricid fauna is rich both because of the number of separate clades it comprises and because of the substantial diversification of four of those clades. The number of separate large muricid clades, even if represented by just one or two species, is thus nine in the northeast Pacific, four in the southeast Pacific (with a fifth counting a Late Pleistocene species of Haustrum: Gordillo \& Nielsen 2013), seven in southern Africa, seven in the Northwest Pacific and Australasia, and three in the North Atlantic.

\section{Material and methods}

The material examined is deposited in the following collections:

CASIZ: California Academy of Sciences, Invertebrate Zoology, San Francisco, U.S.A.

IRSNB: Institut royal des Sciences naturelles de Belgique, Bruxelles, Belgium.

LACM: $\quad$ Natural History Museum of Los Angeles County, Los Angeles, California, U.S.A.

MNHN: $\quad$ Muséum national d'Histoire naturelle, Paris, France.

NHMUK: Natural History Museum, London, United Kingdom.

RH: $\quad$ collection of Roland Houart.

SIO: $\quad$ Scripps Institution of Oceanography, La Jolla, California, U.S.A.

SW: $\quad$ Shawn Wiedrick station numbers.

UCMP: $\quad$ University of California Museum of Paleontology, Berkeley, California, U.S.A.

USNM: National Museum of Natural History, Washington, D.C., U.S.A.

ZIN (or ZISP for types): Zoological Institute of Russian Academy of Sciences, St. Petersburg, Russia.

ZMMSU: Zoological Museum of Moscow State University, Moscow, Russia.

The characters used here to describe the shell morphology address the general aspects of the shell, the shape, size, color, spire characteristics, number of whorls and features of the protoconch, number and shape of the teleoconch whorls, details of the suture, subsutural band, axial and spiral sculpture, aperture, siphonal canal and, when available, the operculum (Figs 4-10).

The method for determining diameter, height and number of protoconch whorls is shown in Figure 1, a method here employed and used by Bouchet \& Kantor (2004). The terminology used to describe the spiral cords and the apertural denticles follows Merle $(2001,2005)$. The morphology of the radula is described starting from the rachidian tooth followed by the lateral teeth (Fig. 2). The bathymetric ranges given herein are the inner values of the recorded depths: the deepest minimum and the shallowest maximum of each recorded depth range.

Unless otherwise mentioned, the new species descriptions are based on the holotype, a representative selection of the paratypes, and occasionally on juvenile specimens. 

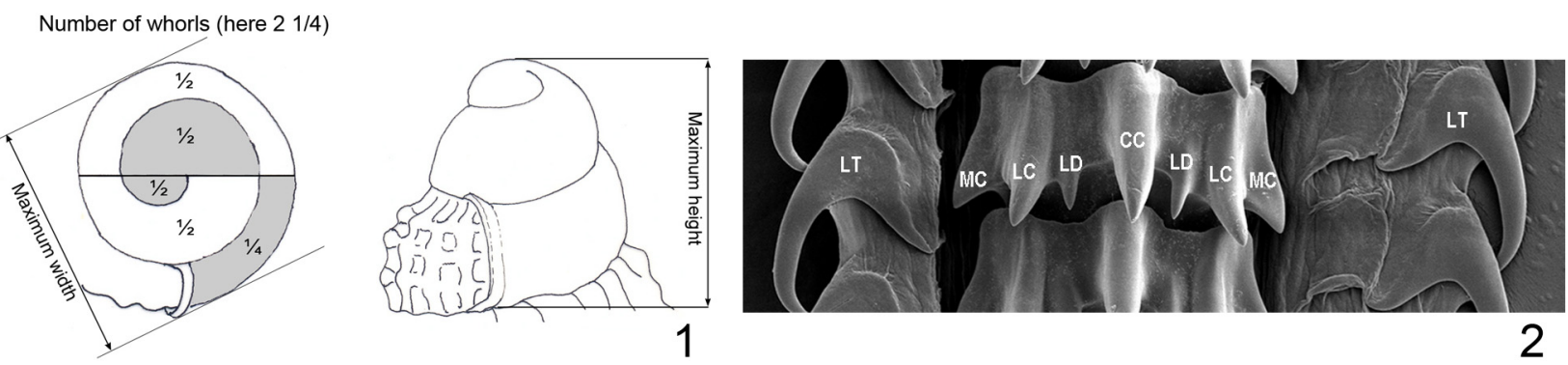

FIGURE 1. Method for determining diameter, height and number of protoconch whorls (scale bars: $500 \mu \mathrm{m}$ ).

FIGURE 2. Terminology used to describe the radula, here. Warenia elegantula (Dall, 1907): CC: central cusp; LD: lateral denticle; LC: lateral cusp; MC: marginal cusp; LT: lateral teeth.

Terminology used to describe the spiral cords and the apertural denticles (after Merle, 2001, 2005)

ab: $\quad$ abapical (or abapertural);

abis: $\quad$ abapical infrasutural secondary cord (on subsutural ramp);

ABP: $\quad$ abapertural primary cord on the siphonal canal;

abs: abapertural secondary cord on the siphonal canal;

ad: $\quad$ adapical (or adapertural);

adis: $\quad$ adapical infrasutural secondary cord (on subsutural ramp);

ADP: $\quad$ adapertural primary cord on the siphonal canal;

ads: $\quad$ adapertural secondary cord on the siphonal canal;

D1 to D6: abapical denticles;

ID: Infrasutural denticle.

IP: $\quad$ infrasutural primary cord (primary cord on subsutural ramp);

MP: $\quad$ median primary cord on the siphonal canal;

ms: $\quad$ median secondary cord on the siphonal canal;

P: $\quad$ primary cord;

P1: $\quad$ shoulder cord;

P2-P6: primary cords of the convex part of the teleoconch whorl;

s: $\quad$ secondary cord;

s1-s6: $\quad$ secondary cords of the convex part of the teleoconch whorl between $\mathrm{Pn}$ and $\mathrm{Pn}+1$;

SP: $\quad$ subsutural cord;

(): $\quad$ term in parenthesis means a variable feature.

\section{Other abbreviations}

M: $\quad$ Monotypy;

OD: $\quad$ Original designation;

SD: $\quad$ Subsequent designation;

lv: $\quad$ live collected specimen(s);

dd: empty shell(s).

\section{Systematics}

Muricidae Rafinesque, 1815

Pagodulinae Barco et al., 2012 


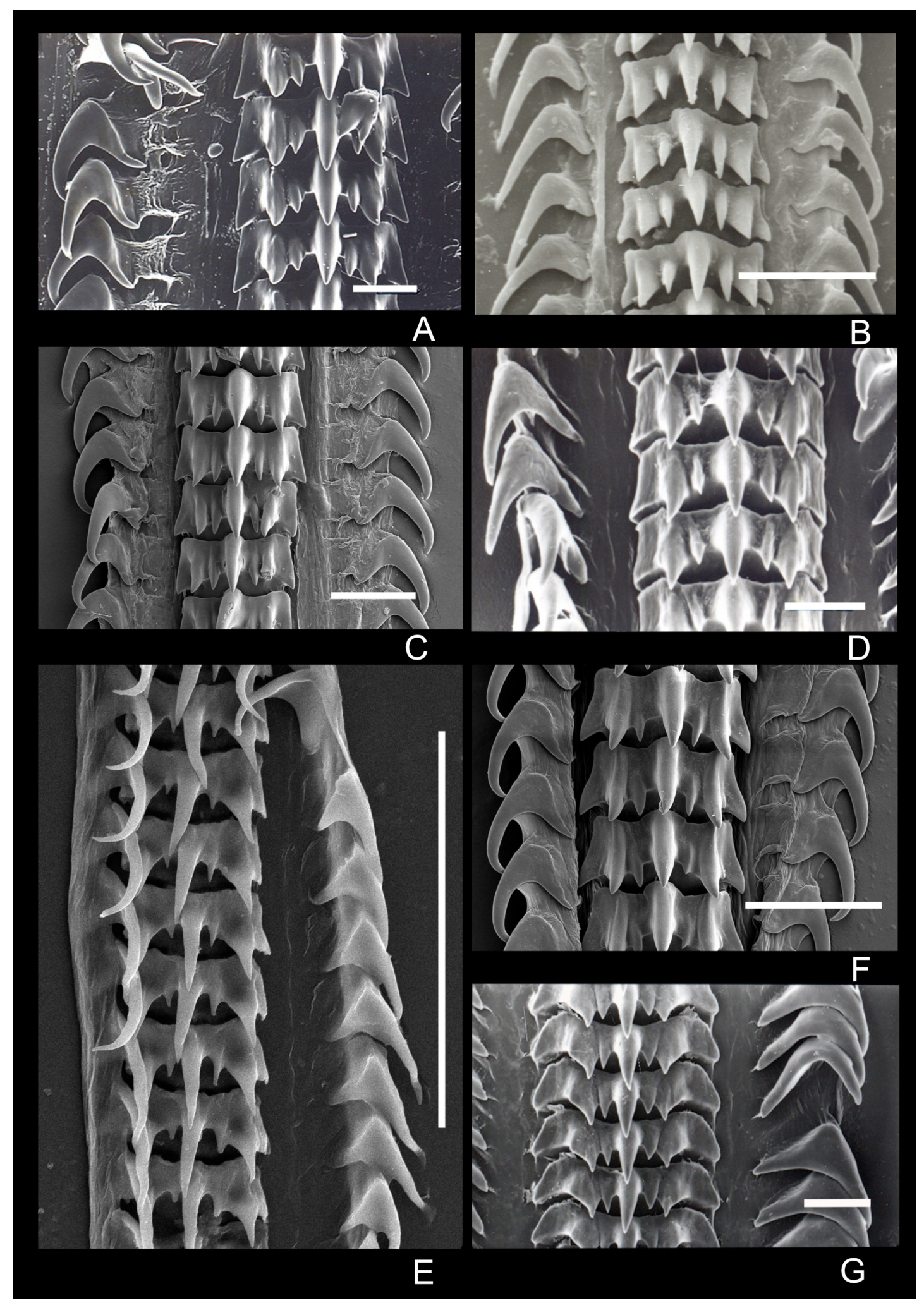

FIGURE 3. Radulae of northeastern Pacific Muricidae. A. Scabrotrophon densilamellatus (Golikov \& Gulbin, 1977), Iturup Islands, Kurile Islands, Russia, RH. B. Scabrotrophon tegularis (Golikov \& Gulbin, 1977), Moneron Island, Southern Sakhalin, Russia, RH. C. Scabrotrophon undocostatus (Golikov \& Sirenko, 1992), Simushir Island, Kurile Islands, RH. D. Scabrotrophon nodulosus (Golikov, 1985), Okhotsk Sea, Sakalin Bay, Russia, RH. E. Scabrotrophon kantori n. sp. off Santa Cruz Island, Santa Barbara County, California, paratype LACM 3445; F. Warenia elegantula (Dall, 1907), Aleutian Islands, south of Attu Island, Alaska, RH. G. Nodulotrophon coronatus (H. \& A. Adams, 1864), Beaufort Sea, Alaska, RH. Scale bars A, C-G: $50 \mu \mathrm{m}$; B: $20 \mu \mathrm{m}$. 
Pagodulidae comprises 17 genera (Barco et al. 2012, 2015, this study). The family is diagnosed in part by sistergroup relationships of molecular phylogeny, in part by radular morphology. The latter is muricine, with the rachidian tooth bearing a major triangular central cusp, a small intermediate denticle on each side, and a lateral cusp slightly smaller than the central one. The rachidian base is subrectangular, broad, anteriorly concave and has no marginal cusps (Fig. 3G). In Trophoninae, the radula is ocenebrine-like with the rachidian teeth bearing five major cusps, two small denticles, one central cusp, a small denticle on each side, and a small lateral and marginal cusp (Fig. 3A-F). Boreotrophon, Abyssotrophon and Nodulotrophon are assigned to Pagodulinae on radular morphology alone (Houart 2001, Barco et al. 2012, Sysoev 1992: 167, Egorov 1993: 4, Fig. 3G).

\section{Abyssotrophon Egorov, 1993}

Abyssotrophon Egorov, 1993: 27. Type species (OD): Abyssotrophon ruthenicus Egorov, 1993. Kurile Islands, abyssal depths.

Diagnosis. Shell broadly convex, fusiform, fragile, usually with shouldered teleoconch whorls, numerous, low, thin axial lamellae; long, occasionally weakly twisted, broadly open siphonal canal. Spiral sculpture absent or consisting of low, rounded, narrow primary cords.

Remarks. Species of Abyssotrophon live in bathyal or abyssal depths, from 140 to over $7000 \mathrm{~m}$, usually between 1000 and $5000 \mathrm{~m}$. They are currently only known from the northern Pacific.

\section{Abyssotrophon fusiformis new species}

(Figure 11A-B)

Type material. San Clemente Basin, California ( $\left.32^{\circ} 35.73^{\prime} \mathrm{N}, 118^{\circ} 08.23^{\prime} \mathrm{W}\right), \mathrm{R} / \mathrm{V}$ Robert Gordon Spoul, Hans G. Kuck, 12-13 September 1989, 1502-1938 m (LACM 1989-30.3), holotype LACM 338620.6 mm, lv.

Distribution. Only from the holotype.

Description. Shell medium sized for the genus, $20.6 \mathrm{~mm}$ in length, length/width ratio 2.6. Slender in shape, lanceolate, narrowly ovate, lightly built, lamellate. Subsutural ramp broad, strongly sloping, weakly convex; color greyish-white, aperture white within. Spire very high with convex teleoconch whorls, weakly angulate, shouldered. Suture impressed, partially obscured by small axial lamellae of following whorl. Protoconch unknown (protoconch, early teleoconch whorls broken). Axial sculpture of teleoconch whorls consisting of numerous, low, thin, fragile lamellae on all whorls, last whorl with approximately 65 lamellae. Spiral sculpture of low, rounded, narrow, primary cords, earlier teleoconch whorls with 2-3 visible cords. Last whorl with P1-P5; P1, P3 more obvious; P2 shallow; P4, P5 indistinct. No cord on subsutural ramp, siphonal canal. Aperture large, ovate; columellar lip narrow, smooth, adherent. Outer lip thin, smooth within. Siphonal canal long, straight, ventrally broadly open.

Remarks. Abyssotrophon fusiformis differs from the similar A. soyae (Okutani, 1959) from Taiwan and Japan (Fig. 11C) in having a narrower shell with a higher spire, less shouldered whorls with a narrower shoulder ramp and less obvious, more numerous spiral cords. It differs from A. ruthenicus Egorov, 1993, from the Kurile Islands (Fig. 11D-E) in having a higher spire, a narrower shell, a smaller aperture, less obvious spiral cords and a straight siphonal canal.

Etymology. Fusiformis (L): having the form of a spindle.

\section{Abyssotrophon newmani new species}

(Figures 4A, 11F-G)

Type material. San Diego Trough, off San Diego, California ( $32^{\circ} 35^{\prime} \mathrm{N}, 117^{\circ} 33.5^{\prime} \mathrm{W}$ ), F. Rokop, $1183-1216$ $\mathrm{m}$, holotype SIO M2807, $15.3 \mathrm{~mm}$, dd (drill hole in front; protoconch, early whorls missing).

Distribution. Only from the holotype. 


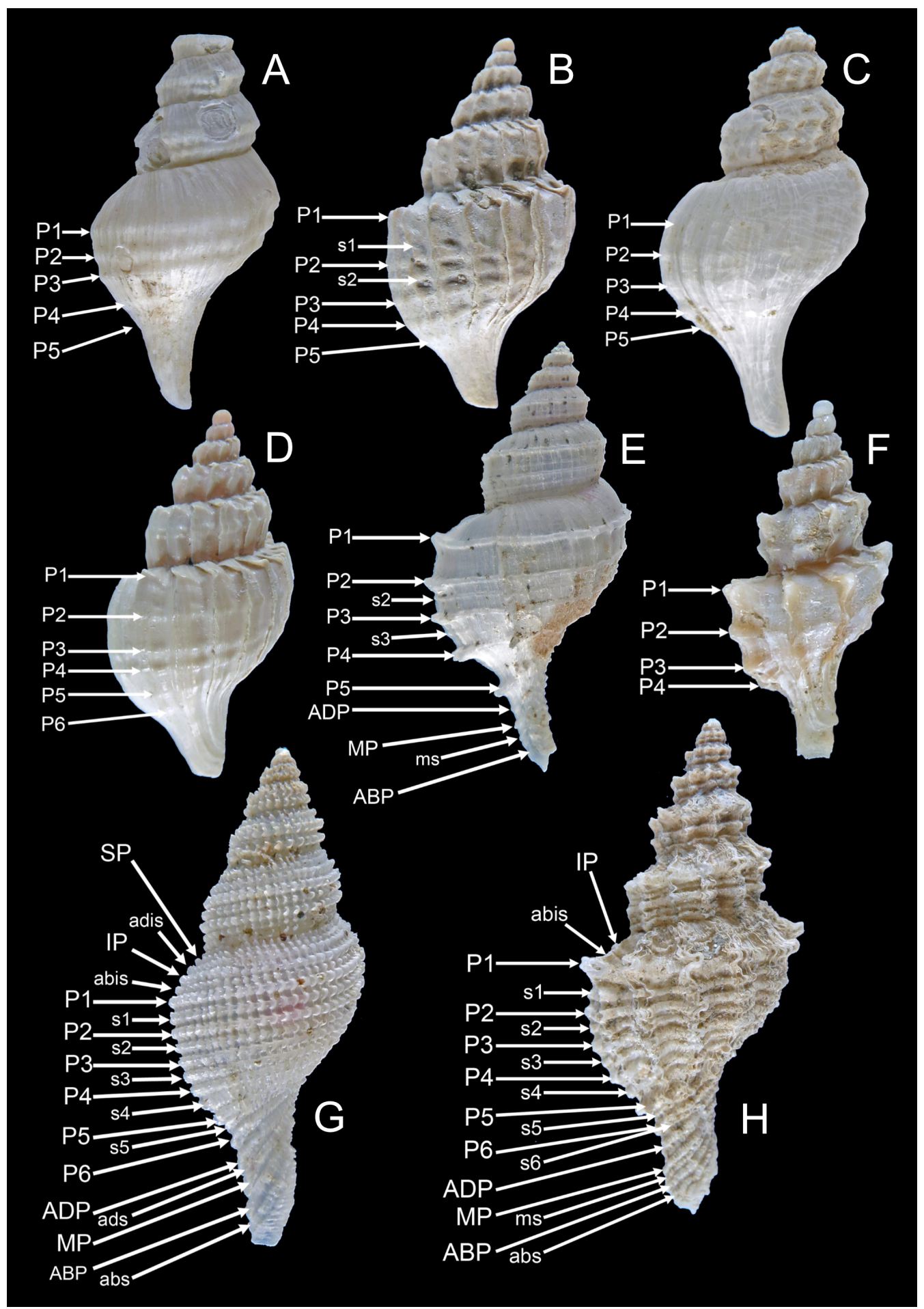

FIGURE 4. Spiral cords morphology of northeastern Pacific Muricidae. A. Abyssotrophon newmani n. sp. San Diego Trough, off San Diego, California, 32 $35^{\prime} \mathrm{N}, 117^{\circ} 33.5^{\prime} \mathrm{W}$, F. Rokop, 1183-1216 m, holotype SIO M2807, 15.3 mm. B. Boreotrophon santarosensis n. sp. off South Point, Santa Rosa Island, Santa Barbara County, 33 50.83' N, 120 05.95' W, 115 m, California, holotype LACM 3415, $10.4 \mathrm{~mm}$. C. Boreotrophon pseudotripherus n. sp. West of Yaquina Head Light, Lincoln County,

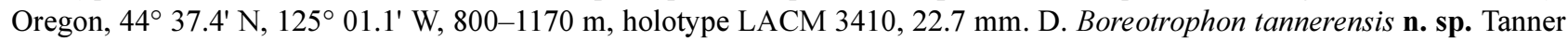
Bank, SW of San Clemente Island, $32^{\circ} 39.04^{\prime} \mathrm{N}, 119^{\circ} 09.6^{\prime} \mathrm{W}, 150 \mathrm{~m}$, California, holotype LACM $3439,10.1 \mathrm{~mm} . \mathrm{E}$. Scabrotrophon buldirensis n. sp. SW of Buldir Island, Aleutian Islands, Alaska (52 $\left.19.77^{\prime} \mathrm{N}, 175^{\circ} 48.56^{\prime} \mathrm{E}\right), 226 \mathrm{~m}$, holotype LACM 3442, 24.7 mm. F. Scabrotrophon kantori n. sp. off Santa Cruz Island, Santa Barbara County, California, 46 m, holotype LACM 3444, 8.9 mm. G. Scabrotrophon lima n. sp. SW of Buldir Island, Aleutian Islands, Alaska (52 $19.77^{\prime} \mathrm{N}, 175^{\circ}$ 48.56' E), 226 m, paratype LACM 3447, 15.7 mm. H. Scabrotrophon macleani $\mathbf{n}$. sp. Miami Islet, Stuart Channel, N of Thetis Island, Strait of Georgia, SE Vancouver Island ( $\left.49^{\circ} 02,0^{\prime} \mathrm{N}, 123^{\circ} 41,2^{\prime} \mathrm{W}\right)$, intertidal British Columbia, holotype LACM 3448 , $23.7 \mathrm{~mm}$. 
Description. Shell medium sized for the genus, $15.3 \mathrm{~mm}$ in length, lanceolate, lightly built. Subsutural ramp broad, strongly sloping, weakly convex. Color greyish-white, aperture white within. Spire high, earlier whorls missing, remaining 3.5 whorls broadly convex, strongly shouldered with impressed suture. Protoconch unknown due to early whorls missing. Axial sculpture of teleoconch whorls consisting of low, almost obsolete, thin, worn, numerous lamellae, more obvious on early whorls and subsutural ramp. Spiral sculpture of low, rounded, narrow, primary cords. Last whorl with P1-P5, P1-P4 similar in strength; P5 narrow, very low, indistinct. Subsutural ramp smooth except for numerous, low, axial lamellae. Penultimate, antepenultimate whorls with visible P1; P2, P3 partly covered by next whorl. Aperture large, ovate; columellar lip, outer lip damaged. Siphonal canal partially broken, long, narrow, straight, broadly open, with low, worn, hardly visible lamellae over whole length.

Remarks. Abyssotrophon newmani differs from the other Abyssotrophon species in having a very broad, strongly sloping, convex, subsutural ramp and close-set primary spiral cords. It differs from A. fusiformis (Fig. $11 \mathrm{~A}-\mathrm{B}$ ) in being less fragile, in having a lower spire, a much broader subsutural ramp, more obvious spiral cords on the last teleoconch whorl and less numerous, shallower axial lamellae.

Etymology. Named after William Newman of the benthic biology program at Scripps Institution of Oceanography, La Jolla, California.

\section{Boreotrophon Fischer, 1884}

Boreotrophon Fischer, 1884: 640.

Type species. (M): Murex clathratus Linnaeus, 1767, northern Atlantic.

Diagnosis. Shell fusiform, spire high; protoconch paucispiral, rounded or shouldered.

Last teleoconch whorl with numerous axial lamellae; spiral sculpture faint if present, not crossing or raised above axial lamellae; suture impressed. Aperture large, ovate, outer lip smooth within; siphonal canal moderately long, broad, broadly open near ventral end.

Remarks. This is a genus of the northern Hemisphere, with numerous species in the Arctic Ocean, the North Atlantic and the North Pacific. Egorov $(1992,1993)$ reviewed the species of the northwest Pacific. Species of Boreotrophon are here treated in two groups: those lacking spiral sculpture and those with substantial spiral sculpture on the convex part of the teleoconch whorls.

Barco et al. (2012: 608) stated that the genus Boreotrophon as currently conceived is possibly polyphyletic as species with different radulae morphology are included in it, and that a thorough revision of the species is needed to assess their actual relationship.

The same problem occurs within the genus Scabrotrophon. This is also relevant in this study if we take as an example B. kamchatkanus and $S$. kantori, commented or described below. Only genetic analysis will be able to give us a precise idea of the classification of these (and other) species. In the meantime they are included in the subfamily and genera that we think are the most appropriate.

\section{Species lacking spiral sculpture}

\section{Boreotrophon alaskanus Dall, 1902}

(Figure 12G-J)

Boreotrophon alaskanus Dall, 1902: 545, 1925, pl. 22, fig.3. Holotype USNM 122594; Bering Sea, north of Unalaska.

Diagnosis. Shell medium sized, up to $50 \mathrm{~mm}$ in length; spire high, suture deep. Protoconch unknown. Last teleoconch whorl strongly shouldered, with 7 or 8 broadly spaced axial lamellae, projecting at shoulder, occasionally upturned with no spiral sculpture. Aperture broad, ovate; siphonal canal long, broadly open ventrally; color white or greyish white.

Remarks. This is a deep-water species known from very few specimens, including the type locality north of Unalaska, and from the Pribilof Islands to the West Bering Sea and from the Okhotsk Sea (Kantor \& Sysoev 2006: pl. 64, fig. G, misidentified as B. ithitomus) at continental slope depths. Russian (Egorov, 1993) and Japanese authors (Habe \& Ito 1965 [in part, pl. 10, figs 12, 16], Tiba \& Kosuge 1985, Tsuchiya 2000, 
2017) have used this name for western Pacific specimens of generally larger size, broader profile with straighter and more numerous axial lamellae, up to 14 on last teleoconch whorl. Boreotrophon alaskanus has stronger and fewer, diagonally slanted, axial lamellae. These Russian and Japanese records are referred to $B$. alborostratus Taki, 1938, which is here removed from the synonymy of B. alaskanus and considered valid. The holotype of B. alaskanus is in poor condition; however, the first illustration provided by Dall (1925: pl. 22, fig. 3, Fig. 12I) represents a carefully considered reconstruction of the spines. Another large and perfect specimen, probably of over $50 \mathrm{~mm}$, was illustrated by Habe \& Ito (1965: pl. 10, fig. 17).

Distribution. West and East Bering Sea, north of Unalaska, 117-600 m.

\section{Boreotrophon cascadiensis new species}

(Figure 11H-L)

Type material. Cascadia Abyssal Plain, Oregon ( $\left.44^{\circ} 39.4^{\prime} \mathrm{N}, 125^{\circ} 36.3^{\prime} \mathrm{W}\right)$, R/V Yaquina (OSU OTB-186 = LACM 1967-165), 26 July 1967, 2800 m, holotype LACM 3387, 30.4 mm, lv. Paratypes: Cascadia Abyssal

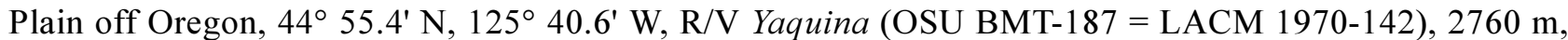
LACM 3388, $1 \mathrm{lv} ; 44^{\circ} 31.9^{\prime} \mathrm{N}, 125^{\circ} 33.5^{\prime} \mathrm{W}$, R/V Yaquina (OSU OTB-131 = LACM 1966-254), $2809 \mathrm{~m}$, LACM 3389, $1 \mathrm{lv} ; 44^{\circ} 47.8 \mathrm{~N}, 125^{\circ} 39.3^{\prime} \mathrm{W}, \mathrm{R} / \mathrm{V}$ Yaquina (OSU OTB-207 = LACM 1967-177), $2810 \mathrm{~m}$, LACM 3390, $1 \mathrm{lv} ; 44^{\circ} 37.8^{\prime} \mathrm{N}, 126^{\circ} 01.6^{\prime} \mathrm{W}$, R/V Yaquina (OSU OTB-91 = LACM 1965-156), $2800 \mathrm{~m}$, LACM 3391, $1 \mathrm{lv} ; 4^{\circ} 46.2^{\prime} \mathrm{N}, 126^{\circ} 01.8^{\prime} \mathrm{W}, \mathrm{R} / \mathrm{V}$ Yaquina (OSU OTB-49 = LACM 1965-132), $2800 \mathrm{~m}$, LACM 3392, 1 lv; Cascadia Abyssal Plain off Washington, 48 $18.60^{\prime} \mathrm{N}, 127^{\circ} 0.90^{\prime} \mathrm{W}, \mathrm{R} / \mathrm{V}$ Yaquina (OSU BMT-DWD 2 = LACM 1971-368), 2560 m, 1 IRSNB I.G.33460/ MT.3573, 1 MNHN-IM-2014-6475.

Other material. Cascadia Abyssal Plain off Oregon, $44^{\circ} 33.1^{\prime} \mathrm{N}, 128^{\circ} 20.3^{\prime} \mathrm{W}$, R/V Yaquina (OSU BMT-

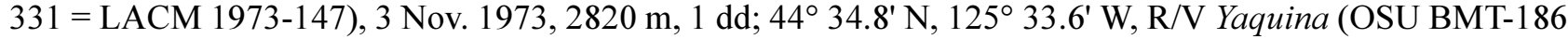
$=$ LACM 1970-141), 16 March 1970, $2816 \mathrm{~m}, 1 \mathrm{lv}, 1 \mathrm{dd} ; 44^{\circ} 36.2^{\prime} \mathrm{N}, 125^{\circ} 35.5^{\prime} \mathrm{W}$, R/V Yaquina (OSU BMT-

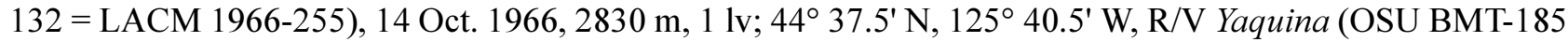
$=$ LACM 1970-140), 16 March 1970, $2816 \mathrm{~m}, 2 \mathrm{lv}, 1 \mathrm{dd} ; 44^{\circ} 37.5^{\prime} \mathrm{N}, 127^{\circ} 31.5^{\prime} \mathrm{W}$, R/V Yaquina (OSU BMT282 = LACM 1971-396), 19 May 1971, $2816 \mathrm{~m}, 2 \mathrm{lv}$; 44 38.4' N, 126 42.2' W, R/V Yaquina (OSU BMT-

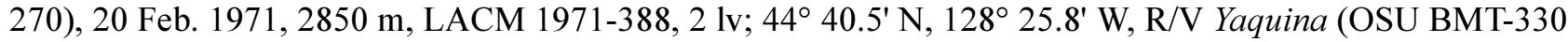
$=$ LACM 1973-146), 3 Nov. 1973, $2794 \mathrm{~m}, 1 \mathrm{dd} ; 44^{\circ} 42.7^{\prime} \mathrm{N}, 125^{\circ} 33.0^{\prime} \mathrm{W}$, R/V Yaquina (OSU BMT-120 = LACM 1969-109), 6 Oct. 1969, $2825 \mathrm{~m}, 1 \mathrm{lv} \& 1 \mathrm{dd} ; 44^{\circ}$ 45.0' N, $127^{\circ} 28.6^{\prime} \mathrm{W}$, R/V Yaquina (OSU BMT-315 $=$ LACM 1973-142), 2 Feb. 1973, $2803 \mathrm{~m}, 2 \mathrm{lv} \& 1 \mathrm{dd} ; 44^{\circ}$ 45.4' N, 125 36.3' W, R/V Yaquina (OSU BMT284 = LACM 1969-89), 1 June. 1969, $2807 \mathrm{~m}, 1 \mathrm{dd} ; 44^{\circ} 45.9^{\prime} \mathrm{N}, 125^{\circ} 36.5^{\prime} \mathrm{W}, \mathrm{R} / \mathrm{V}$ Yaquina (OSU OTB-185 $=$ LACM 1967-164), 25 July 1967, $2800 \mathrm{~m}, 2 \mathrm{dd} ; 44^{\circ} 45.9^{\prime} \mathrm{N}, 125^{\circ} 41.3^{\prime} \mathrm{W}, \mathrm{R} / \mathrm{V}$ Yaquina (OSU OTB-92 = LACM 1965-157), 24 Oct. 1965, $2800 \mathrm{~m}, 1 \mathrm{dd} ; 44^{\circ} 57.7^{\prime} \mathrm{N}, 126^{\circ} 40.0^{\prime} \mathrm{W}, \mathrm{R} / \mathrm{V}$ Yaquina (OSU BMT-269 $=$

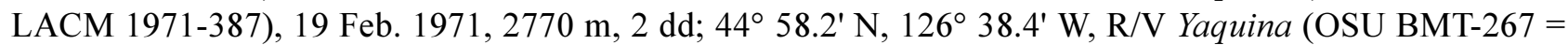

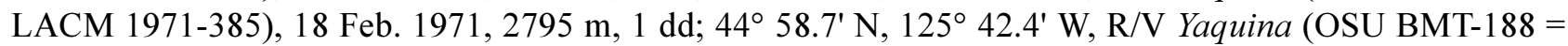

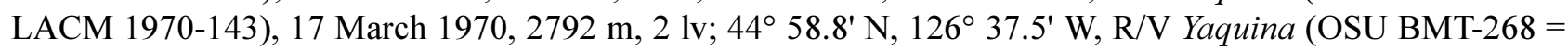
LACM 1971-386), 19 Feb. 1971, $2770 \mathrm{~m}, 30 \mathrm{lv} \& \mathrm{dd} ; 4^{\circ} 01.6^{\prime} \mathrm{N}, 127^{\circ} 31.0^{\prime} \mathrm{W}, \mathrm{R} / \mathrm{V}$ Yaquina (OSU BMT$336=$ LACM 1973-152), 5 Nov. 1973, $2850 \mathrm{~m}, 1 \mathrm{dd} ; 4^{\circ} 02.7^{\prime} \mathrm{N}, 127^{\circ} 32.5^{\prime} \mathrm{W}, \mathrm{R} / \mathrm{V}$ Yaquina (OSU BMT-334

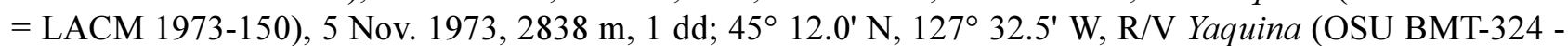

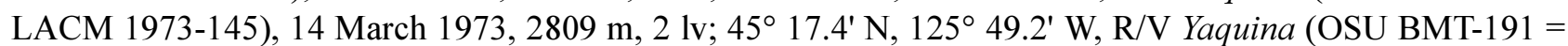
LACM 1970-145), 18 March 1970, $2605 \mathrm{~m}, 2 \mathrm{lv} ; 45^{\circ} 17.5^{\prime} \mathrm{N}, 126^{\circ} 28.5^{\prime} \mathrm{W}, \mathrm{R} / \mathrm{V}$ Yaquina (OSU BMT-266 = LACM 1971-384), 18 Feb. 1971, $2710 \mathrm{~m}, 1 \mathrm{lv} ; 45^{\circ} 22.0^{\prime} \mathrm{N}, 125^{\circ} 37.4^{\prime} \mathrm{W}, \mathrm{R} / \mathrm{V}$ Yaquina (OSU BMT-116 = LACM 1969-105), 04 Oct. 1969, $2634 \mathrm{~m}, 1 \mathrm{dd} ; 45^{\circ} 46.3^{\prime} \mathrm{N}, 126^{\circ} 34.3^{\prime} \mathrm{W}, \mathrm{R} / \mathrm{V}$ Yaquina (OSU BMT-259 = LACM 1971-377), 15 Feb. 1971, $2665 \mathrm{~m}, 1 \mathrm{lv} ; 45^{\circ} 57.6^{\prime} \mathrm{N}, 125^{\circ} 46.2^{\prime} \mathrm{W}, \mathrm{R} / \mathrm{V}$ Yaquina (OSU BMT-195 =

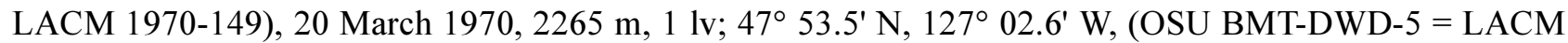

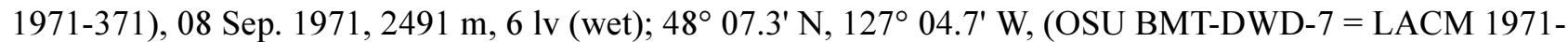
372), 10 Sep. 1971, $2529 \mathrm{~m}, 20 \mathrm{lv}$ (wet); 48 $18.5^{\prime} \mathrm{N}, 127^{\circ}$ 04.2' W, (OSU BMT-DWD-1 = LACM 1971-367), 01 Sep. 1971, 2560 m, 20 lv (wet); 48 21.8' N, 126 55.8' W, (OSU BMT-DWD-3 = LACM 1971-369), 05 Sep. 1971, $2535 \mathrm{~m}, 14 \mathrm{lv}$ (wet).

Distribution. Cascadia abyssal plain, Oregon ( $44^{\circ} 36.2^{\prime}$ to $48^{\circ} 21.8^{\prime} \mathrm{N}$ and $125^{\circ} 33.0^{\prime}$ to $\left.128^{\circ} 25.8^{\prime} \mathrm{W}\right)$, living at $2265-2850 \mathrm{~m}$.

Description. Shell medium sized for the genus, up to $30.4 \mathrm{~mm}$ in length (holotype), length/width ratio 2.1-2.4. Shape slender, lanceolate, lightly built, lamellate; subsutural ramp broad, weakly sloping, weakly 
convex. Color dirty white, aperture white within. Spire very high with teleoconch of broad, weakly convex, strongly shouldered whorls; suture impressed.

Protoconch, early teleoconch whorls missing in all examined specimens, only four teleoconch whorls remaining in adult specimens. Axial sculpture of teleoconch whorls consisting of low, flattened lamellae, more strongly developed at shoulder, producing short, broadly open spines. Last whorl with 8-12 lamellae, similar on previous whorls, other axial sculpture of numerous growth striae. No spiral sculpture except very low P1, producing short, broadly open spines where crossed by axial lamellae. Aperture broadly ovate; columellar lip narrow, smooth, rim adherent; outer lip thin, smooth within. Siphonal canal long, straight, weakly bent to left, broadly open ventrally with low, obsolete axial lamellae over whole length. Operculum light brown, ovate, with apical nucleus.

Remarks. This new species is included in Boreotrophon and not in Abyssotrophon because of its more solid shell, its high axial lamellae and the lack of any spiral sculpture.

Boreotrophon cascadiensis differs from any known abyssal and other Boreotrophon species by its very long and straight, broadly open siphonal canal, combined with low, narrow axial lamellae ending as short, open spines on the shoulder, a very broad, weakly sloping subsutural ramp and a very high spire, although broken in all the numerous examined specimen of B. cascadiensis. It differs from Abyssotrophon christae Egorov, 1992, described from the Gulf of Alaska (Fig. 11M), in having a more solid and larger shell with fewer, broader and flatter lamellae, a broader, less horizontal shoulder ramp, and a comparatively narrower siphonal canal.

It differs from Abyssotrophon ivanovi Egorov, 1992, (Fig. 11N) from the Kurile-Kamchatka trench in having a more solid and larger shell, a longer, straighter and comparatively narrower siphonal canal and straight axial lamellae, compared to the diagonally slanted axials in A. ivanovi.

Etymology. Named after the Cascadia abyssal plain where the specimens were collected.

\section{Boreotrophon cordellensis new species}

(Figure 11O-S)

Type material. Cordell Bank, off Point Reyes, Marin County, California ( $38^{\circ} 01^{\prime} \mathrm{N}, 123^{\circ} 25$ W), R.W. Schmieder, R/V Cordell Explorer, by diving party, 1981-1984, 37-52 m, (LACM 1981-50), holotype LACM 3393, 5.5 mm, dd. Paratypes: 3 dd LACM 3394, 1 dd IRSNB I.G.33460/ MT.3574, 1 dd MNHN-IM-20146476 (from type locality).

Other material. Type locality = LACM 1981-50, $17 \mathrm{dd}$.

Distribution. Only known from the type locality, freshly dead collected specimens at 37-52 m.

Description. Shell small for genus, up to $6.5 \mathrm{~mm}$ in length, length/width ratio $2.3-2.5$. Shell shape slender, lanceolate, narrow, lamellate. Subsutural ramp narrow, weakly sloping, convex. Color light tan with weak, lighter colored axial lamellae, aperture light brown within. Spire very high with 1.5 protoconch whorls, up to four weakly convex, elongate, narrow, weakly shouldered teleoconch whorls; suture impressed. Protoconch large, weakly elongate, whorls smooth, maximum width $600 \mu \mathrm{m}$. Terminal lip low, narrow, weakly curved.

Axial sculpture of teleoconch whorls consisting of low, flattened lamellae, occasionally more strongly developed at shoulder. Last whorl with 13-15 lamellae of various strengths. Spiral sculpture absent, except near suture of P1, occasionally with more strongly developed axial lamellae at shoulder. Aperture small, ovate, columellar lip narrow, smooth, adherent. Outer lip moderately thick, smooth within. Siphonal canal very short, wide, straight, broadly open ventrally.

Remarks. Boreotrophon cordellensis superficially resembles B. pacificus Dall, 1902, (Fig. 13A) but the shell is much smaller, narrower, with a shorter siphonal canal and more numerous axial lamellae.

Etymology. Named after the Cordell Bank where the specimens were collected.

\section{Boreotrophon cortesianus new species}

(Figure 13B-C)

Type material. 40 miles SW of San Clemente Island, Los Angeles County, near Cortes Bank, California, 73$110 \mathrm{~m}$, holotype CASIZ 102992, $19 \mathrm{~mm}$, lv.

Distribution. Known only from the holotype. 
Description. Shell medium sized for genus, $19 \mathrm{~mm}$ in length, lanceolate, biconical, heavy. Subsutural ramp broad, strongly sloping, weakly concave; color dirty white, aperture creamy white within. Shell partly covered by remnants of thick, tan-white intritacalx. Spire high with shouldered teleoconch whorls, suture adpressed. Protoconch, early teleoconch whorls eroded in holotype. Axial sculpture of teleoconch whorls consisting of high, broad ribs; antepenultimate, penultimate whorls with eight ribs, last whorl with seven broad ribs, last two rib with narrow, eroded growth lamellae. Other growth lamellae strongly eroded or obsolete. Spiral sculpture lacking except broad, very low shoulder cord (P1) with strong nodes when crossing axial ribs. Aperture moderately large, ovate; columellar lip narrow, smooth, adherent. Anal notch shallow, broad. Outer lip smooth, thick, interiorly smooth. Siphonal canal partly broken, narrow, straight, ventrally open.

Remarks. The holotype was previously figured as a variant of B. avalonensis Dall, 1902 by McLean (1996: 86, fig. 1.16E), and erroneously mentioned as living at a depth of $40 \mathrm{~m}$.

Boreotrophon cortesianus differs from B. avalonensis (Fig. 13D-E) in having a thicker shell with broader and stronger axial lamellae and a broader siphonal canal. It also differs in lacking the projecting spines at the shoulder and in having a broader, more strongly sloping subsutural ramp and adpressed suture of whorls. Boretrophon cortesianus superficially resembles B. eucymatus Dall, 1902 (Fig. 13F-G) but differs in having a thicker, more solid, and stouter shell, broader, coarser and less numerous axial lamellae with a more strongly sloping subsutural ramp.

Etymology. Named after the Cortes Bank where the specimen was collected.

\section{Boreotrophon obesus new species}

(Figure 13H-L)

Type material. NE of Adak Island, Andreanof Island, Aleutian Islands, Alaska (51 $58.50^{\prime} \mathrm{N}, 176^{\circ} 22.95^{\prime} \mathrm{W}$ ), 121 m, R.N. Clark, R/V Dominator (23-971-122 = LACM 1997-152), 11 July 1997, holotype LACM 3395, $8.4 \mathrm{~mm}$, lv. Paratypes: Inanudak Bay, NW side Umnak Island, Aleutian Islands, Alaska $\left(53^{\circ} 22.38^{\prime} \mathrm{N}, 168^{\circ}\right.$ 34.42' W = LACM 1986-336), R. Baxter, 19 September 1986, 90 m, LACM 3396 , 6.6 mm, 1 dd; N of Carlisle Island, Islands of Four Mountains, Aleutian Islands, Alaska $\left(52^{\circ} 58.53^{\prime} \mathrm{N}, 170^{\circ} 02.60^{\prime} \mathrm{W}=\mathrm{LACM}\right.$ 1986-333), R. Baxter, 18 September 1986, 121 m, 1 lv, LACM 3397.

Distribution. Aleutian Islands, Alaska, living at $121 \mathrm{~m}$.

Description. Shell small for genus, up to $8.4 \mathrm{~mm}$ in length (holotype), probably subadult, length/width ratio 1.8. Broadly biconical in shape, lightly built, lamellae present; subsutural ramp very narrow, weakly sloping, almost horizontal. Color light tan with lighter colored axial lamellae, edge of aperture white, light brown within. Spire moderately high with 1.5 protoconch whorls and up to 3.25 broad, convex, weakly shouldered, lamellate teleoconch whorls; suture impressed. Protoconch small, whorls rounded, smooth, maximum width $650 \mu \mathrm{m}$, terminal lip eroded. Axial sculpture of teleoconch whorls consisting of low, broad, close-set, numerous lamellae. First whorl partly eroded, penultimate whorl with 24-25 lamellae, last with 2531. Spiral sculpture absent, except very subtle sculpture in P1. Aperture large, ovate; columellar lip narrow, smooth, adherent. Outer lip smooth, thin, interiorly smooth. Siphonal canal short, broad, weakly recurved dorsally, broadly open ventrally.

Remarks. Boreotrophon obesus is a very peculiar species that differs from any other Boreotrophon species in having a broad, final teleoconch whorl, a wide, very short siphonal canal, with numerous, low, broad and close-set axial lamellae.

It differs from the more southern Boreotrophon tolomius (Dall, 1919) (Fig. 13M-N) described from off San Miguel Island, southern California, in having a comparatively higher spire, a much narrower, tabulate subsutural ramp, and a broader, much shorter siphonal canal. The three type specimens are probably immature with a maximum of 3.25 teleoconch whorls, but this species is undoubtedly separate from any other known living Boreotrophon species. This small species also differs from any other species of Buccinidae, such as Retifusus species, by its broad, short, broadly open siphonal canal and chiefly in having the typical, narrow axial lamellae of Boreotrophon.

Etymology. Obesus (L): the specific name meaning obese reflects the broad last teleoconch whorl. 


\section{Boreotrophon subapolyonis new species}

(Figure 13O-R)

Type material. Off Tanner Bank, California $\left(32^{\circ} 47.5^{\prime} \mathrm{N}, 119^{\circ} 15.5^{\prime} \mathrm{W}\right), 13$ February $1977,511-530 \mathrm{~m}$, holotype LACM 3398 (ex LACM 1977-250.17), $20.9 \mathrm{~mm}$, dd, and 6 paratypes LACM 3399 (dd, juveniles). Other paratype: off Tanner Bank, SW of San Clemente Island, California ( $\left.32^{\circ} 40.97^{\prime} \mathrm{N}, 119^{\circ} 14.04^{\prime} \mathrm{W}\right), \mathrm{R} / \mathrm{V}$ Velero IV 24368-76, 17 February 1976, 390 m, 14.0 mm (siphonal canal broken) LACM 3400 (ex LACM 1976-313.1), $1 \mathrm{dd}$.

Distribution. Off Tanner Bank, California, dredged dead in 390-511 m.

Description. Shell medium sized for genus, up to $20.9 \mathrm{~mm}$ in length at maturity (holotype), length/width ratio 2.3 (holotype). Shape slender, lanceolate, broadly ovate, lightly built; subsutural ramp broad, weakly sloping, almost straight. Color dirty white; aperture white within. Spire high, acute with 1.5 protoconch whorls, up to five moderately broad, strongly shouldered, lamellate teleoconch whorls, suture impressed. Protoconch small, whorls rounded, smooth, maximum width $800 \mu \mathrm{m}$. Terminal lip shallow, straight. Axial sculpture of teleoconch whorls consisting of low, thin, weakly diagonally slanted lamellae, slightly more developed at shoulder. Last, penultimate teleoconch whorls of holotype with 15 lamellae; antepenultimate whorl with 16 lamellae. Spiral sculpture absent, except P1 with weak axial lamellae developing into very short, broad, spine-like projections. Aperture large, ovate; columellar lip narrow, smooth, adherent. Outer lip thin, smooth. Siphonal canal moderately long, narrow, weakly bent to the left, broadly open ventrally.

Remarks. Boreotrophon subapolyonis differs from B. apolyonis (Dall, 1919) (Fig. 14A-B) in its higher spire, more slender profile, more numerous and diagonally slanted axial ribs. All specimens analyzed were collected empty. Paratype LACM 3400 was identified by McLean (1996: 87, fig. 1.17B) as Boreotrophon apolyonis (Dall, 1919).

Etymology. Sub: Latin word element meaning "close to", here close to apolyonis.

\section{Boreotrophon vancouverensis new species}

(Figure 14C-G)

Type material. Entrance to Bull Harbor, Hope Island ( $\mathrm{N}$ end Vancouver Island), Rupert District, British Columbia, Canada $\left(50^{\circ} 54.1^{\prime} \mathrm{N}, 127^{\circ} 56.3^{\prime} \mathrm{W}\right)$, intertidal to $2 \mathrm{~m}$, J.H. McLean \& I. Cowan, 21 May 1963, holotype LACM 3401 (ex LACM 1963-29.19), $16.6 \mathrm{~mm}$, lv, and 4 paratypes LACM 3402 (ex LACM 196329.19), lv. Other paratypes (from type locality): 1 lv IRSNB I.G.33460/ MT.3575 and 1 lv MNHN-IM-20146477.

Other material. British Columbia: E side of Port Alexander Inlet, Nigei Island, Rupert District, Vancouver Island (50 $\left.51^{\prime} \mathrm{N}, 127^{\circ} 39^{\prime} \mathrm{W}\right)$, intertidal, May 1963, LACM 1963-32.18, 6 lv; Entrance to Bull Harbor, Hope Island ( $\mathrm{N}$ end Vancouver Island), Rupert District, ( $50^{\circ} 54.1^{\prime} \mathrm{N}, 127^{\circ} 56.3^{\prime} \mathrm{W}$ ), intertidal to $2 \mathrm{~m}$, May 1963, 41 LACM 1963-29.19 (all lv); Hope Island, Rupert District, Vancouver Island, May, 1963, LACM 15392, 2 lv; Bear Cove, Port Hardy, Rupert District, Vancouver Island, April 2006, intertidal, under, on top and on sides of boulders along highway, LACM 173692, 4 lv; Ramsay Island, SE of Lyell Island, Juan Perez Sound, E side Moresby Island, Queen Charlotte Islands District (52 $\left.36.3^{\prime} \mathrm{N}, 131^{\circ} 30.6^{\prime} \mathrm{W}\right)$, February 1970, 18 m, LACM 1970-93.14, 3 lv; Entrance to Naden Harbour, N side of Graham Island, Queen Charlotte Islands

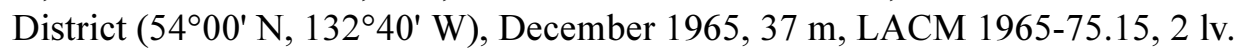

Alaska: Taylor Bay Corner, Port Dick, S coast Kenai Peninsula, Kenai-Cook Inlet County, $\left(59^{\circ} 16^{\prime} \mathrm{N}\right.$, $151^{\circ} 05^{\prime}$ W), July 1983, intertidal, LACM 1983-63.20, 2 lv; SW reef, Port Chalmers, NW side Montague Island, Prince William Sound, Valdez-Cordova County $\left(60^{\circ} 14.5 \mathrm{~N}, 147^{\circ} 17.5^{\prime} \mathrm{W}\right)$, intertidal, June 1965 , LACM 1965-176.10, 1 dd; Forrester Island, Prince of Wales Hyder Census Area, Alaska, LACM 59603, 10 lv $\&$ dd; Prince of Wales Island, Prince of Wales County, LACM 150746, 10 lv \& dd.

Distribution. British Columbia, Canada, Vancouver Island, and Port Dick, S. coast Kenai Peninsula and Prince of Wales Island, Alaska, intertidal to $37 \mathrm{~m}$ depth.

Description. Shell small for genus, up to $16.6 \mathrm{~mm}$ in length, length/width ratio 2.1-2.4. Shape lanceolate, broadly ovate, lightly built; subsutural ramp very narrow, tabulate, weakly concave. Color light brown with lighter colored axial lamellae, edge of aperture white, brown or light brown within. Spire high, with 1.5 protoconch whorls, up to 6 moderately broad, convex, shouldered, lamellate sculptured teleoconch whorls. Suture impressed, partially obscured by axial lamellae of following whorl. Protoconch small, whorls rounded, 
smooth, maximum width $650 \mu \mathrm{m}$. Terminal lip shallow, almost straight. Axial sculpture of teleoconch whorls consisting of moderately high, thin, strong abaperturally curved lamellae, broader, higher at shoulder. First teleoconch whorl with 9-10 lamellae, second with 9-11, third to last whorl with 10-12 lamellae. Spiral sculpture absent except P1 producing somewhat more developed axial lamellae at shoulder. Aperture moderately small, broadly ovate; columellar lip narrow, smooth, rim adherent. Outer lip moderately broad, smooth within; siphonal canal short, broad, straight, very weakly recurved dorsally, broadly open ventrally, with low axial lamellae over entire length.

Remarks. This differs from B. pacificus (Fig. 13A) by the smaller size, shorter siphonal canal, light brown coloration, and its crested axial lamellae that project at the shoulder. It differs from B. multicostatus (Eschscholtz, 1829) (Fig. 14H) in having a comparatively smaller shell with a higher spire, a shorter siphonal canal and more numerous axial lamellae on the last teleoconch whorl (10-12) compared to B. multicostatus $(8-9)$.

Etymology. Named after Vancouver Island where the specimens were collected.

\section{Species with substantial spiral sculpture except on siphonal canal}

\section{Boreotrophon aleuticus new species}

(Figure 14I-M)

Type material. NE of Semisopochnoi Island, Rat Islands, Aleutian Islands, Alaska (52 $21.44^{\prime} \mathrm{N}, 179^{\circ} 49.23^{\prime}$ $\mathrm{W}=$ LACM 1986-329), R. Baxter, 10 September 1986, 168 m, holotype LACM 3403, 8.4 mm, lv. Paratypes: off village of Makushin, Makushin Bay, NW side Unalaska Island, Aleutian Islands, Alaska (53 $46.16^{\prime} \mathrm{N}$, 16658.83' W = LACM 1986-301), 18 m, R. Baxter, 20 September 1986, LACM 3404, 1 dd (fragment); west of Tanaga Island, Andreanof Islands, Aleutian Islands County, Alaska $\left(51^{\circ} 44.50^{\prime} \mathrm{N}, 178^{\circ} 7.68^{\prime} \mathrm{E}=\mathrm{LACM}\right.$ 1997-154), 95 m, R.N. Clark, RV Dominator, 15 July 1997, LACM 3405, 2 dd; Sitkin Strait, Adak Island, Andreanof Islands, Aleutian Islands, County, Alaska (5154.8' N, 176 ${ }^{\circ} 50.6^{\prime} \mathrm{W}=$ LACM 1997-186), 103 m, shell fragments, R.N. Clark, RV Dominator, 23 July 1997, LACM 3406, 2 dd; SE side Petrel Bank, NE of Semisopochnoi Island, Rat Islands, Aleutian islands, County, Alaska $\left(52^{\circ} 10.34^{\prime} \mathrm{N}, 179^{\circ} 59.09^{\prime} \mathrm{W}=\mathrm{LACM}\right.$ 1986-326), 165 m, R. Baxter, 8 September 1986, LACM 3407, 1 lv; NE end Petrel Bank, NE of Semisopochnoi Island, Rat Islands, Aleutian Islands County, Alaska $\left(52^{\circ} 18.00^{\prime} \mathrm{N}, 179^{\circ} 54.50^{\prime} \mathrm{W}=\mathrm{LACM}\right.$ 1986-328), 113 m, R. Baxter, 10 September 1986, LACM 3408, 1 lv, juv.; NE of Adak Island, Andreanof Islands, Aleutian Islands, Alaska ( $\left(1^{\circ} 58.50^{\prime} \mathrm{N}, 176^{\circ} 22.95^{\prime} \mathrm{W}\right), 121$ m, R.N. Clark, R/V Dominator (sta. 23971-122 = LACM 1997-152), 11 July 1997, LACM 3409 (1 lv, 1 dd).

Distribution. Aleutian Islands, Alaska, living at $121-168 \mathrm{~m}$.

Description. Shell small for genus, up to $8.7 \mathrm{~mm}$ in length (paratype LACM 3406), length/width ratio 1.9-2.1. Shape lanceolate, biconical, broadly ovate, lightly built, subsutural ramp broad, strongly sloping, weakly convex. Color entirely white. Spire high with 1.5 protoconch whorls and up to four broad, strongly convex teleoconch whorls; suture impressed. Protoconch comparatively large, weakly shouldered, smooth, maximum width $700 \mu \mathrm{m}$. Terminal lip delicate, thin, low, very weakly curved. Axial sculpture of teleoconch whorls consisting of numerous, low, weak, thin, close-set lamellae, of same height from suture to tip of siphonal canal, more flattened on siphonal canal. Last teleoconch whorl of holotype with more than 60 lamellae; penultimate with approximately 40 lamellae; antepenultimate with $38-40$; previous whorls partly eroded or with damaged lamellae. Spiral sculpture of very low, lightly rounded, shallow, broad, primary cords. Last whorl with P1-P6; P1-P4 of approximately same breadth, height; P5-P6 lower, narrower, indistinct. Aperture moderately large, ovate; columellar lip narrow, smooth, rim adherent. Outer lip thin, smooth. Siphonal canal short, comparatively narrow, straight, broadly open ventrally, with numerous, low lamellae over entire length.

Remarks. The largest shell (paratype LACM 3406) may not be fully adult with only four teleoconch whorls, but the form of the shell, the number and pattern of the axial lamellae is very peculiar and cannot be confused with any other species.

Etymology. Named after the Aleutian Islands where the specimens were collected. 
Boreotrophon kamchatkanus Dall, 1902

(Figures 12A-F)

Boreotrophon kamchatkanus Dall, 1902: 541, 1921: pl. 10, fig. 7. Syntype USNM 109178; SE coast Kamchatka, R/V Albatross 3644, $29 \mathrm{~m}$ (see below).

Trophonopsis nanus Egorov, 1994: 100, pl. 1, figs G, H. Holotype ZMMSU Lc-21262; 3959.8' N - 3959.5' N, $142^{\circ} 14.5^{\prime} \mathrm{E}-$ $142^{\circ} 12.9^{\prime} \mathrm{E}, 194 \mathrm{~m}$ (new synonym).

Diagnosis. Shell medium sized, up to $25 \mathrm{~mm}$ in length, broadly fusiform; spire high; suture weakly impressed. Protoconch unknown. Subsutural ramp convex, strongly sloping. Last teleoconch whorl weakly shouldered, broadly convex, with close-set, narrow, low axial ribs. Spiral sculpture of narrow, smooth cords of nearly equal strength, absent from shoulder ramp. Aperture large, broadly ovate; siphonal canal short or moderately long, broadly open near ventral end, weakly curved; color white.

Remarks. The present species has been assigned to both Boreotrophon (e.g., Dall 1902, this paper) and Scabrotrophon (e.g. Houart \& Moffitt 2010). It is here reassigned to Boreotrophon. The decisive character is the absence of spiral sculpture on the siphonal canal in B. kamchatkanus. All Scabrotrophon species have spiral sculpture on the siphonal canal except $S$. kantori $n$. sp., which is here tentatively assigned in Scabrotrophon (see below).

The depth of Albatross station 3644 was cited wrong by Dall (1902) as $96 \mathrm{fms}$, In checking the original publication, the depth was listed as 96 feet (=16 fathoms). This was transcribed as $96 \mathrm{fms}$ on a label that had depth pre-printed in fathoms. It seems now clear that the correct depth for St. 3644 is $96 \mathrm{ft}$ (=16 fms or $29 \mathrm{~m})$ (Harasewych in litt., Houart \& Moffit 2010).

Trophonopsis nanus Egorov, 1994 is a young specimen of B. kamchatkanus.

The maximum depth of $1495 \mathrm{~m}$ given by Tsuchiya (2000: 401) seems doubtful for living specimens (Houart \& Moffitt 2010).

Distribution. Kashima-nada, Japan, Okhotsk and Western Bering Sea to Eureka, California, 29-400 m.

\section{Boreotrophon pseudotripherus new species}

(Figures 4C, 14N-R)

Type material. West of Yaquina Head Light, Lincoln County, Oregon ( $\left.44^{\circ} 37.4 \mathrm{~N}, 125^{\circ} 01.1 \mathrm{~W}\right), \mathrm{R} / \mathrm{V}$ Acona (OSU OTB-6), 800-1170 m, May 1963, holotype LACM 3410 (ex LACM 1963-121.1), 22.8 mm, lv.

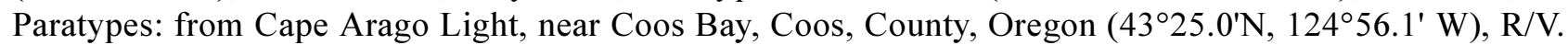
Cayuse (OSU IT8-496), 800 m, April 1973, LACM 3411 (ex LACM 1973-132.4), 2 lv.; from Yaquina John

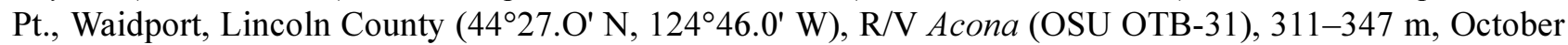
1961, LACM 3412 (ex LACM 1961-45.1), 1 lv; from Yaquina Head Light, Lincoln County (44³6.6' N, 1245‥ $3^{\prime}$ W), R/V Yaquina (OSU OTB-209), 800 m, October 1967, LACM 3413 (ex LACM 1967-179.5), 1

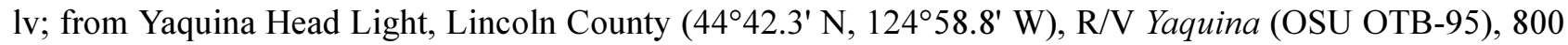
m, June 1965, LACM 3414 (ex LACM 1965-145.4), 1 lv.

Other material. From Yaquina Head Light, Lincoln County, Oregon $\left(44^{\circ} 38.2^{\prime} \mathrm{N}, 124^{\circ} 50.5^{\prime} \mathrm{W}\right), \mathrm{R} / \mathrm{V}$ Acona (OSU AD-51), 800 m, June 1963, LACM 1963-108.2, 1 dd; from Yaquina Head Light, Lincoln County, Oregon (4443.9' N, 12458.3' W) R/V Yaquina (OSU OTB-103), December 1965, LACM 1965-

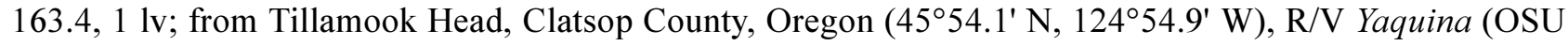
OTB-204), October 1967, LACM 1967.174.6, 1dd.

Distribution. Oregon, $43^{\circ} 25.0^{\prime}$ to $45^{\circ} 54.1^{\prime} \mathrm{N}$ and $124^{\circ} 46.0^{\prime}$ to $125^{\circ} 01.1^{\prime} \mathrm{W}$, living at $347-800 \mathrm{~m}$.

Description. Shell medium sized for genus, up to $22.8 \mathrm{~mm}$ in length (holotype), length/width ratio 2.12.3. Shape slender, broadly ovate, lightly built, tuberculate; subsutural ramp broad, weakly sloping, convex. Shell color entirely white. Spire high, teleoconch up to five broad, convex, weakly angulate, weakly shouldered, nodose whorls; suture impressed. Protoconch, early teleoconch whorls eroded or broken in all examined specimens. Axial sculpture of teleoconch whorls consisting of low, narrow, diagonally slanted ribs, occasional growth lamellae. Last whorl with 14-18 ribs; penultimate, antepenultimate whorls with 12-13 ribs. Spiral sculpture of low, weak, primary cords, last teleoconch whorl with five cords (P1-P5), penultimate with visible P1-P3. Axial ribs, spiral cords forming small knobs at intersection. Aperture large, broadly ovate; columellar lip narrow, smooth, rim adherent. Outer lip smooth, thin, interiorly smooth. Siphonal canal long, 
narrow, twisted, broadly open ventrally. Operculum dark brown, ovate, with apical nucleus.

Remarks. Boreotrophon tripherus Dall, 1902 (Fig. 15A-B) has no spiral cords, no beaded intersection with axial sculpture, and has a narrower and less rounded profile of the final whorl. Boreotrophon disparilis (Dall, 1891) (Fig.15C-D) has more numerous diagonally slanted axial ribs and less obvious nodes at intersection of axial ribs and spiral cords, and has an obviously broader, more globose last teleoconch whorl.

Etymology. Pseudo $(\mathrm{G})=$ false. Named for its resemblance with Boreotrophon tripherus.

\section{Boreotrophon santarosensis new species}

(Figures 4B, 15E-I)

Type material. Off South Point, Santa Rosa Island, Santa Barbara County, California $\left(33^{\circ} 50.83^{\prime} \mathrm{N}, 120^{\circ}\right.$ 05.95' W), R/V Velero IV 22973-75, 14 October 1975, 115 m, holotype LACM 3415 (ex LACM 1975-319.3), $10.3 \mathrm{~mm}$, dd, and 2 paratypes LACM 3416, dd. Off South Point, Santa Rosa Island, Santa Barbara County, California $\left(33^{\circ} 50.99 \mathrm{~N}, 120^{\circ} 04.91^{\prime} \mathrm{W}\right)$, R/V Velero IV 22974-75, 14 October 1975, $103 \mathrm{~m}, 4$ paratypes LACM 3417 (ex LACM 1975-320.3), dd; Oil platform, off Santa Barbara, Santa Barbara County, California $\left(34^{\circ} 23.01^{\prime} \mathrm{N}, 119^{\circ} 56.94^{\prime} \mathrm{W}\right), \mathrm{R} / \mathrm{V}$ Velero IV 23247-75, 10 November 1975, $100 \mathrm{~m}, 3$ paratypes LACM 3438 (ex LACM 1975-468.4), dd.

Distribution. Santa Rosa Island and Santa Barbara, California, in 100-115 m (all dd).

Description. Shell small for the genus, up to $13.8 \mathrm{~mm}$ in length (LACM 3438), length/width ratio 2.02.2. Shape lanceolate, broadly ovate, lightly built and lamellate; subsutural ramp narrow, weakly sloping, weakly concave. Shell color greyish-white.

Spire high with 1.6-1.75 protoconch whorls; up to five broad, convex, strongly shouldered teleoconch whorls; suture impressed. Protoconch small, rounded or weakly elongate, whorls convex and smooth, maximum width $600 \mu \mathrm{m}$. Terminal lip shallow, delicate, weakly curved. Axial sculpture of teleoconch whorls consisting of low, thin lamellae, more strongly developed at shoulder, producing short, narrow spine-like projections. Lamellae on first teleoconch whorl with 10-12; second, third 11-14; fourth 14, last whorl 13-15. Spiral sculpture of low, rounded, narrow, smooth, primary, secondary cords. First whorl with visible, low P1; P2 visible on second whorl with P3 partially covered by next whorl; third whorl with P1-P3; fourth whorl of subadult shell with P1, starting s1, P2, starting s2, P3, P4 and P5; fifth whorl of holotype with P1, s1, P2, s2, P3, starting s3, P4 and P5. P1-P4 similar in size, strength; P5 narrower, lower. Aperture moderately small, ovate; columellar lip narrow, smooth, rim adherent. Anal notch shallow, broad; outer lip thin, smooth. Siphonal canal short, narrow, straight, weakly bent to left, broadly open ventrally.

Remarks. Boreotrophon santarosensis differs from the other species of Boreotrophon in having a broader final teleoconch whorl, together with a narrow, almost horizontal subsutural ramp, and more elaborate spiral cord morphology.

Etymology. Named after Santa Rosa Island where the specimens were collected.

\section{Boreotrophon tannerensis new species}

(Figures 4D, 15J-L)

Type material. Tanner Bank, SW of San Clemente Island, California ( $\left.32^{\circ} 39.04^{\prime} \mathrm{N}, 119^{\circ} 09.6^{\prime} \mathrm{W}\right), \mathrm{R} / \mathrm{V}$ Velero IV 24671-76 (= LACM 1976-416), 150 m, 10 April 1976, holotype LACM 3439, $10.2 \mathrm{~mm}$, dd and 11 paratypes LACM 193440 (dd, all small juv.). Off E side Santa Rosa Island, California (33 $51.9^{\prime} \mathrm{N}, 119^{\circ} 55.0^{\prime}$ W), R/V Velero IV 22948-75 (= LACM 1975-300), 115 m, 13 October 1975, 2 paratypes LACM 3441, dd, juv.

Distribution. SW of Clemente Island, California $\left(32^{\circ} 39.04^{\prime} \mathrm{N}\right)$ to E side of Santa Rosa Island, California $\left(33^{\circ} 51.9^{\prime} \mathrm{N}\right)$, in $115-150 \mathrm{~m}(\mathrm{dd})$.

Description. Shell small for genus, up to $10.2 \mathrm{~mm}$ in length (holotype), length/width ratio 2.0. Broadly biconical, lightly built, lamellate; subsutural ramp narrow, weakly sloping, almost horizontal, weakly concave. Shell color entirely greyish-white with light tan protoconch. Spire high with 1.75-2 protoconch whorls, up to 4.3 broad, convex, strongly shouldered teleoconch whorls; suture impressed. Protoconch moderately large, whorls rounded, smooth, first whorl weakly shouldered in some specimens, maximum width $650 \mu \mathrm{m}$. Terminal lip shallow, delicate, thin, weakly curved. Axial sculpture of teleoconch whorls consisting of low, thin lamellae, more strongly developed at shoulder, producing short, narrow spine-like 
projections. Lamellae on first whorl 10-13, second 13, fourth 12, last whorl 14. Spiral sculpture of low, rounded, narrow, smooth, primary, rarely secondary cords. First whorl only with shoulder cord P1 visible, occasionally starting P2; second whorl of juvenile specimen with P1, P2; P3 indistinct; third whorl of juveniles with three teleoconch whorls of P1, P2, (s2), P3; P4 indistinct. Last whorl of holotype with P1-6; P6 indistinct. Space between P2, P3 almost twice size than between other cords. Aperture moderately large, ovate; columellar lip narrow, smooth, rim adherent. Anal notch shallow, broad; outer lip thin, smooth; siphonal canal short, broad based, tapered abapically, broadly open ventrally, with very low lamellae over entire length.

Remarks. The spiral cord morphology in B. tannerensis, particularly the broader space between $\mathrm{P} 2$ and P3, is not observed in any other species of Boreotrophon. It differs from B. santarosensis (Figs 4B, 15E-I) in having more rounded teleoconch whorls, a narrower, less sloping subsutural ramp, and smaller cords,

Etymology. Named after the Tanner Bank where the holotype was collected.

\section{Trophoninae Cossmann, 1903}

\section{Scabrotrophon McLean, 1996}

Scabrotrophon McLean, 1996: 93. Type species (OD): Trophon maltzani Kobelt \& Küster, 1878, northeast Pacific.

Diagnosis. Shell small to medium in size, $10-60 \mathrm{~mm}$ in length; spire high; protoconch paucispiral of 1.5 wellseparated whorls, axial sculpture consisting of lamellae or ribs; spiral sculpture of rounded, squamous, narrow spiral cords; subsutural ramp with spiral cords, rarely smooth. Aperture moderately large, ovate or broadly ovate, outer lip thin or moderately thick, smooth within; siphonal canal short or moderately long, ventrally open (see also under Boreotrophon).

Remarks. Assignment of species to either Boreotrophon or Sabrotrophon are tentative, with some characters being contradictory. See remarks under Boreotrophon for details.

\section{Scabrotrophon buldirensis new species}

(Figures 4E, 15M-P)

Nipponotrophon scitulus. Egorov, 1993: fig. 36A-B (non Dall, 1891)

Type material. SW of Buldir Island, Aleutian Islands, Alaska (52 $\left.19.77^{\prime} \mathrm{N}, 175^{\circ} 48.56^{\prime} \mathrm{E}\right)$, R/V Dominator 23-971-241 (= LACM 1997-167), R.N. Clark, 9 August 1997, 226 m, holotype LACM 3442, 24.7 mm, lv; 1 paratype LACM 3443 (LACM 1997-167), lv.

Other material. Off Amchitka Island, Aleutian Islands, Alaska ( $\left.51^{\circ} 27.70^{\prime} \mathrm{N}, 178^{\circ} 35.0^{\prime} \mathrm{E}\right), \mathrm{R} / \mathrm{V}$ Dominator 23-971-181 (= LACM 1997-156), R.N. Clark, 27 July 1997, 384 m, 1 lv.

Distribution. Aleutian Islands, Alaska, living at 226-384 m. Egorov (1993) recorded specimens from $760 \mathrm{~m}$ (see remarks).

Description. Shell medium sized for the genus, up to $28.5 \mathrm{~mm}$ in length at maturity (paratype LACM 3443), length/width ratio 2.3-2.5. Shape slender, lanceolate, weakly spinose, fragile; subsutural ramp broad, weakly sloping, weakly convex. Shell color entirely white. Spire high, with five or more weakly convex, angulate, strongly shouldered, weakly spinose whorls; suture impressed. Protoconch broken, unknown. Axial sculpture of teleoconch whorls consisting of low, weak, thin, lamellae, more strongly developed at shoulder, producing short, narrow, spine-like projections. First teleoconch whorl eroded or broken in material examined. Lamellae numerous, well-developed on early whorls, decreasing in number abapically, 11-14 lamellae on last whorl, more than 30 on penultimate, early whorls. Spiral sculpture of low, strong, narrow, rounded primary, occasionally secondary cords. Penultimate, antepenultimate whorls with visible P1, s1, P2, s2, P3; early whorls with P1, (s1), P2, (s2), P3; other whorls broken. Last whorl with P1, P2, s2, P3, (s3), P4, P5, ADP, MP, (ms), ABP. Subsutural ramp smooth except low axial lamellae and growth striae. Aperture large, ovate; columellar lip broad, flaring, smooth, rim erect, small portion adherent at adapical extremity. Anal notch shallow; outer lip thin, smooth. Siphonal canal long, narrow, weakly abaxially bent to left, ventrally open, with spiral cords ADP, MP, ABP low in profile. 
Remarks. Scabrotrophon norafosterae (Figs 5B, 17G-L) is differentiated under that species. Scabrotrophon buldirensis differs from S. scitulus (Fig. 15Q) in having a thinner, lighter shell with obviously narrower, lower spiral cords, a more convex subsutural ramp and a narrower siphonal canal.

A specimen from LACM 1997-156 (Fig. 15P), is tentatively assigned to the new species described here. It has a similar fragile shell with a high spire and a narrow siphonal canal but differs in being more strongly shouldered, in having a less convex subsutural ramp, less numerous axial lamellae and spiral cords, and a longer, more twisted siphonal canal.

Etymology. Named after Buldir Island where the holotype was collected.

\section{Scabrotrophon kantori new species}

(Figures 3E, 4F, 16A-C)

Type material. Off Santa Cruz Island, Santa Barbara County, California, 30 September 1917, 46 m, holotype LACM 3444 (ex LACM 150844), lv, 8.9 mm and 4 paratypes LACM 3445 (ex LACM 150844), lv.

Other material. Santa Catalina Island, Los Angeles County, California, 55 m, LACM 178875, 3 lv; Santa Catalina Island, Los Angeles County, California, 50 m, LACM 150841, 1 dd.

Description. Shell small for genus, up to $10.6 \mathrm{~mm}$ in length (LACM 578875), length/width ratio 2.0-2.1. Shape lanceolate, slender, lightly built; subsutural ramp moderately broad, weakly sloping, weakly convex. Shell color entirely white, occasionally with very light, tan colored axial lamellae. Spire high with 1.5 protoconch whorls; up to five angulate, strongly shouldered teleoconch whorls; suture impressed. Protoconch small, weakly elongate, mostly keeled adapically, smooth, maximum width $600 \mu \mathrm{m}$. Axial sculpture of teleoconch whorls consisting of high, thin lamellae, more strongly developed at shoulder, producing short, broadly open spine-like projections. First whorl with 8-9 lamellae, second with 9-10, third with 9-11, fourth with 8-10, last whorl with 8-9 lamellae. Spiral sculpture of moderately high, rounded, narrow, primary cords. Cords shallow or obsolete on first teleoconch whorls. Antepenultimate, penultimate whorls with visible P1, P2, occasionally with P3, partially covered by next whorl. Last whorl with P1-P4 decreasing in strength abapically. Shoulder cord (P1) broadest with small broadly opened spinelets at intersection with axial lamellae. P3-P4 closer to each other than P1-P2; no spiral sculpture on subsutural ramp. Aperture small, broadly ovate; columellar lip narrow, smooth, rim adherent. Outer lip smooth, moderately thick, smooth within; siphonal canal short, narrow, weakly recurved dorsally, broadly open ventrally, with low lamellae over entire length. Operculum light brown, ovate with apical nucleus. Radula (Fig. 3E) with rachidian tooth bearing long, narrow, weakly projecting central cusp, narrow, lateral denticle, long, broad, lateral cusp, short, acute marginal cusp; lateral teeth sickle-shaped with broad base.

Remarks. Scabrotrophon kantori was originally mixed with several other species in LACM lots, among them a young $S$. stuarti (E.A. Smith, 1880) (new combination), Boreotrophon tannerensis, B. pedroanus and another, unknown Boreotrophon species. Scabrotrophon kantori differs from these species in having a broader final teleoconch whorl, a higher, more acute spire with narrower whorls, less numerous axial ribs, shallower and narrower spiral cords, a smaller, lightly adapically keeled elongate protoconch and a narrower siphonal canal. It differs from young specimens of $S$. stuarti (Fig. 16D-E) in having a narrower, smaller, adapically keeled protoconch rather than the larger, more broadly, rounded protoconch of $S$. stuarti, and has narrower, more strongly shouldered teleoconch whorls, with less obvious, narrower spiral cords.

The decision to include this new species in Scabrotrophon rather than in Boreotrophon is mostly based on the typical three-dimensional radula (Fig. 3E), which bears a short, narrow and acute marginal cusp on each extremity of the rachidian tooth, as in other Trophoninae (Fig. 3A-D, F), but also on the shell morphology, which is closer to Scabrotrophon even if the siphonal canal apparently does not have the usual spiral cords.

Barco et al. (2012: 608) stated that only a thorough revision will be able to assess the actual relationship of some species of Boreotrophon. This also applies to Scabrotrophon and only genetic analysis will be able to give us a precise idea of the classification of some species. In the meantime they are included in the genera that we think are the most appropriate.

Distribution. Santa Cruz and Santa Catalina Islands, California, living at 46-55 m.

Etymology. This species is named after Yuri Kantor, in recognition of his help in radula preparation and SEM work, including for this particular species. 


\section{Scabrotrophon lima new species}

(Figures 4G, 16F-I)

Type material. S of Sturdevant Rock, off NW side Kiska Island, Rat Islands, Aleutian Islands, Alaska (52 ${ }^{\circ}$ 03.54' N, $177^{\circ} 20.63^{\prime}$ E = LACM 1986-314), R. Baxter, 28 August 1986, 168 m, holotype LACM 3446, lv. Paratypes: SW of Buldir Island, Aleutian Islands, Alaska (52 $\left.19.77^{\prime} \mathrm{N}, 175^{\circ} 48.56^{\prime} \mathrm{E}\right)$, R/V Dominator 23 971-241 (= LACM 1997-167), 9 August 1997, 226 m, LACM 3447, 15.7 mm, lv.

Distribution. Aleutian Islands, Alaska, living at $168-226 \mathrm{~m}$.

Description. Shell small for genus, to $15.7 \mathrm{~mm}$ in length (paratype LACM 3447), length/width ratio $2.2-$ 2.5. Shape lanceolate, biconical, narrowly-ovate, lightly built, squamous; subsutural ramp broad, strongly sloping, weakly convex. Shell color entirely white. Spire high with 1.5 protoconch whorls up to five weakly convex, weakly shouldered teleoconch whorls. Suture impressed, obscured by small axial lamellae of following whorl. Protoconch small, smooth, first whorl strongly shouldered, last whorl rounded, maximum width $700 \mu \mathrm{m}$. Terminal lip broad, raised, very weakly curved. Axial sculpture of teleoconch whorls consisting of numerous, low, thin lamellae, giving rise to broadly open, blunt scales at intersection with spiral cords. Last partially broken whorl of holotype with more than 45 lamellae, penultimate whorl with 46-48 lamellae. Spiral sculpture of high, rounded, narrow, squamous primary, secondary cords. First whorl with visible P1-2; second, third whorls with IP, P1, P2, s2, starting adis and s1, fourth whorl with adis, IP, starting abis, P1, s1, P2, s2; last whorl with SP, adis, IP, abis, P1, s1, P2, s2, P3, s3, P4, s4, P5, s5, P6, ADP, ads, MP, ABP, abs. Primary, secondary cords on convex part of teleoconch whorl approximately similar in size, strength. Aperture moderately large, ovate; columellar lip narrow, smooth, rim adherent. Anal notch shallow; outer lip thin, smooth within. Siphonal canal moderately long, narrow, almost straight, ventrally open, with squamous spiral cords ADP, ads, MP, ABP, abs. Operculum light brown, ovate, with apical nucleus.

Remarks. Scabrotrophon lima belongs to a group of species with numerous axial lamellae and obvious, close-set, spiral cords. It includes $S$. tegularis (Golikov \& Gulbin, 1977), S. densilamellatus (Golikov \& Gulbin, 1977), S. undocostata (Golikov \& Sirenko, 1992) and S. nodulosa (Golikov, 1985), all from Okhotsk Sea. They all belong to Trophoninae as can be seen from their radula morphology (Fig. 3A-D), more specifically to Scabrotrophon. Scabrotrophon lima differs from $S$. tegularis (Fig. $16 \mathrm{~J}-\mathrm{K}$ ) in having a more delicate shell, narrower and more numerous spiral cords, more numerous and thinner axial lamellae, narrower and more numerous scales, a convex subsutural ramp as opposed to a concave ramp in $S$. tegularis, and a comparatively narrower siphonal canal. Scabrotrophon lima is compared to $S$. moresbyensis under the remarks section of that species.

Etymology. Lima (L): the specific name relating to the finely scabrous, file-like, shell surface. Noun in apposition.

\section{Scabrotrophon macleani new species}

(Figures 4H, 16L-N)

Type material. Miami Islet, Stuart Channel, N Thetis Island, Cowichian District, Vancouver Island, British Columbia $\left(49^{\circ} 2^{\prime} \mathrm{N}, 123^{\circ} 41.2^{\prime} \mathrm{W}\right), 0$ m. J.N. Allan, Fisheries Research Board Canada, 24 August 1972, holotype LACM 3448 (ex LACM 1972-146.3), 23.7 mm, 5 paratypes LACM 3449 (ex LACM 1972-146.3), all lv.

Distribution. Only known from the type material.

Description. Shell medium sized for the genus, up to $24.1 \mathrm{~mm}$ in length at maturity (LACM 3449), length/width ratio 2.2-2.3. Shape slender, lanceolate, heavy, weakly spinose, squamous; subsutural ramp moderately broad, weakly sloping, concave. Color dirty white. Spire high, up to seven narrow, weakly convex, strongly shouldered teleoconch whorls; suture impressed. Protoconch unknown, broken in all specimens examined. Axial sculpture of teleoconch whorls consisting of high, moderately broad, nodose, weakly spinose ribs. Last teleoconch whorl with 8-10 ribs, penultimate with 9-10, antepenultimate with 1011; early whorls with 9-13 ribs. Spiral sculpture of high, strong, rounded, narrow, squamous, primary, secondary cords. Early whorls with visible P1-2; antepenultimate whorl starting IP, secondary cords s1, sometimes s2. Last whorl with adis, IP, P1, s1, P2, s2, P3, s3, P4, s4, P5, s5, P6, s6, ADP, MP, ms, ABP, abs. Primary cords almost similar in size and strength; secondary cords weakly narrower, also similar in size, strength; spiral cords of siphonal canal lower, narrower. Aperture moderately large, ovate; columellar lip 
narrow, smooth, rim partially erect or adherent. Anal notch shallow, broad; outer lip thick, erect, crenulate, smooth within. Siphonal canal short, narrow, straight, very slightly recurved dorsally, with obvious spiral cords ADP, MP, ms, ABP, abs, decreasing in strength abapically.

Remarks. Scabrotrophon macleani differs from S. maltzani (Kobelt \& Küster, 1878) (Fig. 16O-P) in having broader and higher axial ribs, a more concave and comparatively narrower subsutural ramp, broader primary and secondary cords and no tertiary cords. It differs from $S$. grovesi (Fig. 16Q) in having broader secondary spiral cords, a broader spire and spiral cords on subsutural ramp while remaining smooth in $S$. grovesi, except for axial lamellae.

Etymology. The species is named after James H. McLean, author of numerous malacological papers and driving force of the review of northeast Pacific Gastropoda.

\section{Scabrotrophon moresbyensis new species}

(Figures 5A, 17A-B)

Type material. Off $\mathrm{N}$ end of Moresby Island, Queen Charlotte Islands, British Columbia, Canada $\left(53^{\circ} 01^{\prime} \mathrm{N}\right.$, $132^{\circ} 56^{\prime} \mathrm{W}$ ), $1170 \mathrm{~m}, \mathrm{R} / \mathrm{V}$ G. B. Reed, F.R. Bernard, 10 August 1967, holotype LACM 3450 (ex LACM 196731.6), $11.4 \mathrm{~mm}, \mathrm{lv}$.

Distribution. Only from the holotype.

Description. Shell small for genus, $11.4 \mathrm{~mm}$ in length, length/width ratio 2.3. Shell slender, lanceolate, narrowly ovate, heavy, squamous; subsutural ramp narrow, strongly sloping, almost straight. Shell color entirely white. Spire high, with five or more weakly convex, narrow, weakly shouldered, squamous teleoconch whorls. Suture impressed, partially obscured by axial lamellae of following whorl. Protoconch, first teleoconch whorl broken. Axial sculpture of teleoconch whorl consisting of low, thin, frondose lamellae, more strongly developed at shoulder ramp; 31-33 lamellae on last teleoconch whorl, more numerous on penultimate whorl, less on previous whorls. Spiral sculpture of high, strong, rounded, narrow primary cords and narrow, low, secondary cords. Last teleoconch whorl with IP, P1, s1, P2, s2, P3, P4, P5, s5, P6, s6, ADP, ads, MP, ABP, abs. Previous whorls with visible P1-3, partially covered by following whorl. Aperture moderately small, ovate; columellar lip narrow, smooth, rim adherent. Anal notch shallow, narrow; outer lip thin, smooth within. Siphonal canal moderately long, narrow, straight, broadly open ventrally, with squamous spiral cords ADP, ads, MP, ABP, abs. Operculum light brown, ovate, with apical nucleus.

Remarks. The single specimen is probably somewhat immature but is of interest because of the considerable depth record and its differences with other species.

Scabrotrophon moresbyensis differs from S. scitulus (Fig. 15Q) in having a narrower, less concave subsutural ramp with obvious, narrow, axial lamellae and in having an IP spiral cord, absent in $S$. scitulus. It also has secondary cords on the convex part of the teleoconch whorls while these are missing in $S$. scitulus. It differs from $S$. lima in having a less scabrous and heavier shell with fewer and obviously smaller secondary spiral cords. Scabrotrophon lima has several spiral cords on the more convex subsutural band and numerous secondary cords with a similar size to the primary cords. Scabrotrophon moresbyensis is also close to $S$. norafosterae (Figs 5B, 17G-L) but differs in having a heavier shell, a more strongly sloping and narrower subsutural ramp, a narrower space between the primary cords on the convex part of the teleoconch whorl, in lacking tertiary spiral cords and in having a less shouldered shell.

Etymology. Named after Moresby Island where the holotype was collected.

\section{Scabrotrophon norafosterae new species}

(Figures 5B, 17G-L)

Type material. S of Attu, Near Islands, Aleutian Islands, Alaska ( $\left.52^{\circ} 29.30^{\prime} \mathrm{N}, 172^{\circ} 57.50^{\prime} \mathrm{W}\right), \mathrm{R} / \mathrm{V}$ Dominator (sta. 23-971, 210), R.N. Clark, 2 August 1997, 166 m, holotype LACM 3451 (ex LACM 1997163.17), $23.5 \mathrm{~mm}$, lv and 4 paratypes LACM 3452 (ex LACM 1997-163.17), lv. Paratypes: S of Adak, Andreanof Islands, Aleutian Islands, Alaska (51 $\left.33.49^{\prime} \mathrm{N}, 176^{\circ} 45.5^{\prime} \mathrm{W}\right), \mathrm{R} / \mathrm{V}$ Dominator 23-971-114 (= LACM 1997-151), R.N. Clark, 10 July 1997, 1 dd LACM 3453, 177 m. 


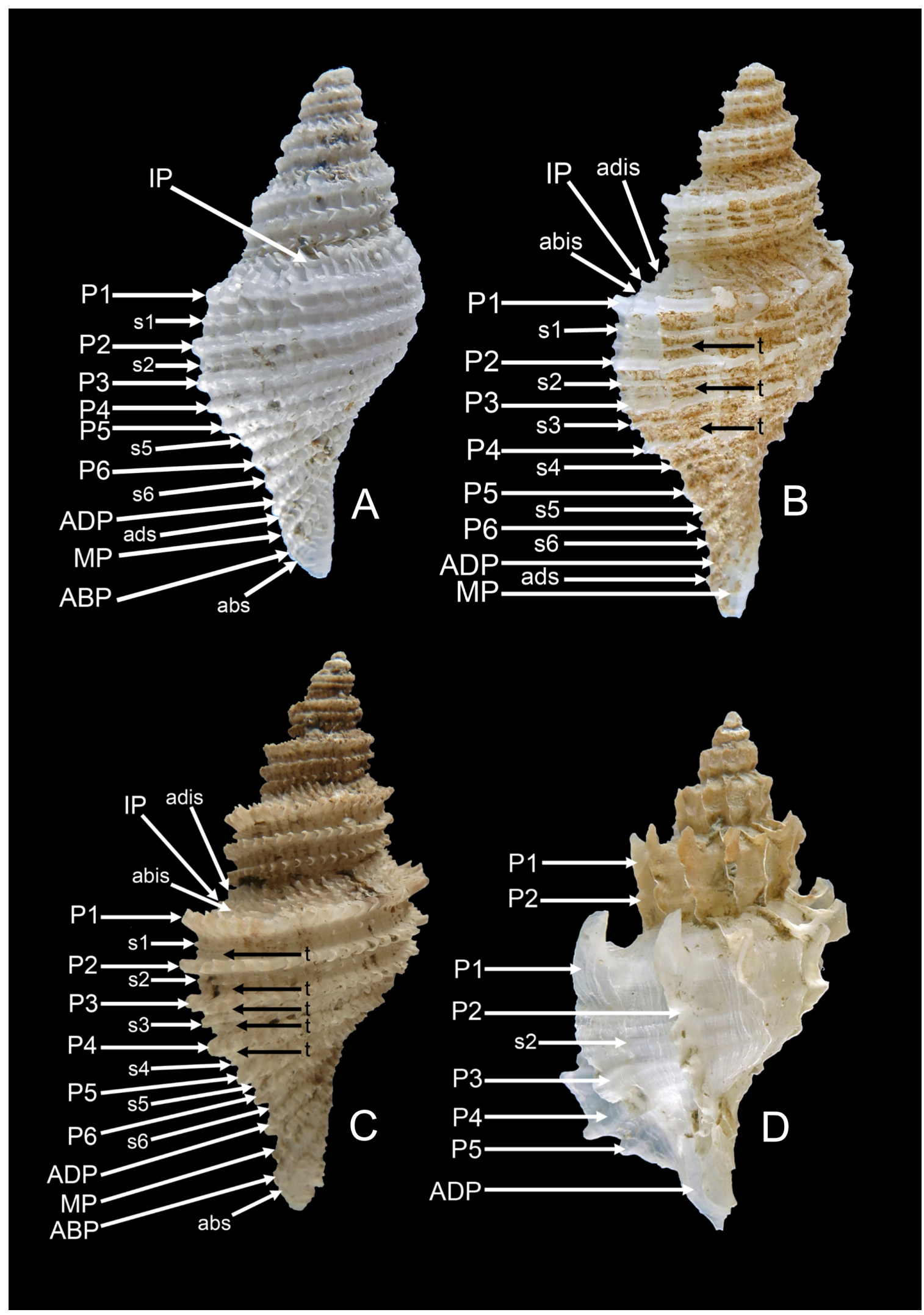

FIGURE 5. Spiral cords morphology of northeastern Pacific Muricidae. A. Scabrotrophon moresbyensis $\mathbf{n} . \mathbf{s p}$. Off N end Moresby Island, Queen Charlotte Islands, British Columbia, 53 01' N, 132 56' W, 1170 m, holotype LACM $3450,11.4$ mm. B. Scabrotrophon norafosterae n. sp. S of Attu, Near Island, Aleutian Islands, Alaska (52 $\left.29.30^{\prime} \mathrm{N}, 172^{\circ} 57.50^{\prime} \mathrm{W}\right), 166 \mathrm{~m}$, holotype LACM 3451, 23.5 mm. C. Scabrotrophon trifidus $\mathbf{n}$. sp. S of Kiska Island, Rat Islands, Aleutian Islands, Alaska, 51 ${ }^{\circ}$ 45.77' N, $177^{\circ} 20.76^{\prime}$ E, 160 m. Holotype LACM 3454, 24 mm. D. Nipponotrophon exquisitus $\mathbf{n}$. sp. SW of Chirkof Island, SE of Semedi Island, Alaska, $54^{\circ} 58.70^{\prime} \mathrm{N}, 157^{\circ} 18.16^{\prime} \mathrm{W}, 167 \mathrm{~m}$, holotype LACM 3455, $16.3 \mathrm{~mm}$. 
Other material. SSW of Ingestrem Rocks, E of Agattu Island, near Islands, Aleutian Islands, Alaska (52 29.7' N, 174² 21.94' E = LACM 1986-305), 263 m, 23 August 1986, 1 lv, juv. NE of Semisopochnol Island, Rat Islands, Aleutian Islands, Alaska $\left(52^{\circ} 07.85^{\prime} \mathrm{N}, 179^{\circ} 55.52^{\prime} \mathrm{W}=\mathrm{LACM} 1986-327\right) 135 \mathrm{~m}$, 9 September 1986, 1 dd, juv.

Distribution. Aleutian Islands, Alaska, living at $166-263 \mathrm{~m}$.

Description. Shell medium sized for genus, up to $27.3 \mathrm{~mm}$ in length at maturity (LACM 3453), length/ width ratio $2.2-2.5$. Shape slender, lanceolate, weakly spinose, lightly built; subsutural ramp moderately broad, weakly sloping, weakly convex or straight. Shell color entirely white. Spire high, acute, with 6-7 weakly convex, strongly shouldered, spinose teleoconch whorls; suture impressed. Protoconch unknown, broken or eroded in all specimens. Axial sculpture of teleoconch whorls consisting of low, weak, thin lamellae, variable in strength and number, decreasing in number abapically. Holotype with 13 lamellae on last whorl, 19 on penultimate, 21 on antepenultimate, more numerous on early whorls. Spiral sculpture of high, rounded, narrow, squamous, primary, secondary and tertiary cords. Last teleoconch whorl with adis, IP, abis, P1, s1, t, P2, s2, (t), P3, s3, (t), P4, s4, P5, s5, (t), P6, s6, ADP, ads, MP, ms. P1-P3 approximately similar in strength, P4-P5 weakly higher and broader, P6 smaller, cords on canal smaller yet. Aperture moderately large, ovate; columellar lip narrow, smooth, rim adherent. Anal notch shallow, narrow; outer lip thin, smooth. Siphonal canal long, narrow, straight or weakly twisted, broadly open ventrally, with spiral cords ADP, ads, MP.

Remarks. Scabrotrophon norafosterae differs from S. maltzani (Fig. 16O-P) in having a much thinner shell, lower, shallower spiral cords on the subsutural ramp, higher, narrower, and more scaly primary spiral cords on the convex part of the teleoconch whorl, narrower secondary cords and a comparatively longer and narrower siphonal canal.

Scabrotrophon norafosterae differs from S. scitulus (Fig. 15Q) in having a much thinner shell with a less concave subsutural ramp, bearing primary and secondary cords compared to the smooth ramp in S. scitulus, with the exception of low axial lamellae. Scabrotrophon norafosterae also has a shell with numerous secondary, and a few tertiary cords on the convex part of the teleoconch whorl, as opposed to the very few or absent secondary cords in S. scitulus. Scabrotrophon norafosterae was mixed with S. buldirensis (Fig. 15MP) in the originally examined material, but it differs from this species in having spiral cords on the subsutural ramp, a scalier shell and more numerous secondary cords. The number of axial lamellae in $S$. norafosterae is variable, from 13 on the last teleoconch whorl in the holotype to more than 20 on a larger but partially broken paratype (Fig. 17I-J).

Etymology. This species is named after Nora Foster, retired from University of Alaska Museum who sent very useful material to the senior author.

\section{Scabrotrophon trifidus new species}

(Figures 5C, 17C-D)

Type material. South of Kiska Island, Rat Islands, Aleutian Islands, Alaska ( $\left.51^{\circ} 45.77^{\prime} \mathrm{N}, 177^{\circ} 20.76^{\prime} \mathrm{E}\right), \mathrm{R} / \mathrm{V}$ Dominator 23-971-194 (= LACM 1997-158), R.N. Clark, 30 July 1997, 160 m, holotype LACM 3454, 24 mm, lv.

Distribution. Only from the holotype.

Description. Shell medium sized for genus, $24 \mathrm{~mm}$ in length, length/width ratio 2.3. Shell shape lanceolate, narrowly ovate, heavy, strongly squamous; subsutural ramp broad, weakly sloping, strongly concave. Color dirty white, aperture glossy white. Spire high, with six moderately broad, strongly shouldered, lightly spinose, strongly squamous teleoconch whorls. Suture impressed, partially obscured by small axial lamellae of following whorl. Protoconch, first teleoconch whorls eroded. Axial sculpture of teleoconch whorls consisting of low, thin, lamellae, more strongly developed when crossing spiral cords, giving rise to long, narrow, open scales. Last teleoconch whorl with 40 lamellae, slightly more numerous on penultimate, antepenultimate whorls. Spiral sculpture of high, strong, rounded, narrow, squamous primary cords; very narrow secondary, tertiary cords. Last teleoconch whorls with SP, adis, IP, abis, P1, s1, t, P2, s2, t, P3, t, s3, t, P4, t, s4, P5, s5, P6, s6, ADP, MP, ABP, abs. Previous whorls with obvious visible P1-P3. Aperture moderately small, ovate; columellar lip narrow, smooth, erect on small portion abapically, otherwise adherent. Anal notch shallow, broad; outer lip thin, crenulate, smooth within. Siphonal canal moderately short, narrow, straight, broadly open ventrally, with spiral cords ADP, MP, ABP, abs. Operculum light brown, ovate with apical nucleus. 
Remarks. Scabrotrophon trifidus markedly differs from S. norafosterae (Figs 5B, 17G-L) in having a more strongly scabrous shell with numerous and thinner axial lamellae, a concave subsutural ramp opposed to weakly convex or straight in $S$. norafosterae, higher, squamous primary spiral cords, comparatively narrower secondary cords and more obvious cords on the shorter siphonal canal. Moreover, in S. norafosterae the P4 and P5 spiral cords are broader and higher than the other cords compared to the similar height of P1-P4, lower P5 and small P6 in S. trifidus. There is a resemblance to S. rossicus (Egorov, 1993) (Fig. 17E-F), which also has projecting cords, but that species has two, rather than three cords, on the early whorls and the penultimate whorl, and does not have tertiary spiral cords or the projecting imbrications of trifidus.

Etymology. From the Latin trifidus "cleft in three", divided into three lobes, relating to the particular form of the early whorls.

\section{Nipponotrophon Kuroda \& Habe, 1971}

Nipponotrophon Kuroda \& Habe, 1971: 233 (Japanese), 152 (English). Type species (OD): Boreotrophon echinus Dall, 1918. Japan.

Diagnosis. Shell small to medium in size, $20-50 \mathrm{~mm}$ in length; spire high; protoconch paucispiral, axial sculpture consisting of lamellae; spirals of few, rounded, smooth cords; subsutural ramp smooth except axial lamellae. Aperture moderately large, broadly ovate, outer lip thin or moderately thick, smooth within; siphonal canal moderately long, ventrally open; absence or reduced presence of spiral cord on siphonal canal.

\section{Nipponotrophon exquisitus new species}

(Figures 5D, 18A-B)

Type material. SW of Chirkof Island, SE of Semedi Island, Alaska ( $\left.54^{\circ} 58.70^{\prime} \mathrm{N}, 157^{\circ} 18.16^{\prime} \mathrm{W}\right), \mathrm{F} / \mathrm{V}$ Dominator, NMFS Gulf of Alaska Trawl Survey, sta. 23-991-78, R.N. Clark, 3 June 1999, 167 m, holotype LACM 3455, $16.3 \mathrm{~mm}$, lv.

Distribution. Only known from the holotype.

Description. Shell small for genus, $16.3 \mathrm{~mm}$ in length, partially broken. Slender in shape, biconical, weakly spinose, lightly built; subsutural ramp moderately broad, weakly sloping, weakly concave. Shell color entirely white. Spire high, with five or more, broad, weakly convex, strongly shouldered, lamellately sculptured teleoconch whorls; suture impressed. Protoconch, first whorls eroded. Axial sculpture of teleoconch whorls consisting of high, thin, fragile lamellae, more strongly developed at shoulder, producing narrow, broadly open, adapically projecting spines. Other axial sculpture of low, weak, narrow growth lamellae. Last teleoconch whorl with nine lamellae; penultimate, previous whorls with 12-14 lamellae; first, second whorls eroded. Spiral sculpture of low, rounded, broad, smooth, primary cords. Last teleoconch whorl with P1, P2, s2, P3, P4, P5, weak, very small ADP; P1 broadest, P2 smaller, P3-P5 similar in strength. Previous whorls with visible P1-P2, P3 partly covered by subsequent teleoconch whorl. Intersection of spiral cords with axial lamellae producing small, broad spines, chiefly on last teleoconch whorl. Subsutural ramp smooth except low, flattened axial lamellae. Aperture broad, ovate; columellar lip narrow, smooth, lip adherent. Anal notch shallow, broad; outer lip erect, thin, smooth within. Siphonal canal partly broken, narrow, broadly open ventrally, with weak, narrow ADP.

Remarks. Nipponotrophon magnificus (Golikov \& Sirenko, 1992) from the Kurile Islands (Fig 18C-D) has higher spire whorls with less obvious P2 cord on early whorls, absent P2 and P4 cords on last whorl, and a more strongly sloping and broader subsutural ramp.

Etymology. Exquisitus (L), meaning excellent, exquisite, a beauty.

\section{Warenia new genus}

(Figures 3F, 18E-J)

Type species. Boreotrophon elegantulus Dall, 1907: 165, here designated. Recent, Alaska (Holotype, USNM 110501).

Description. Shell narrowly fusiform with narrow and elongate teleoconch whorls. Teleoconch whorls weakly convex from suture to suture with very narrow, nearly obsolete shoulder ramp and few thin, low, axial 
lamellae; no spiral sculpture except microscopic, numerous striae on all whorls; siphonal canal short, very narrow with low, broad, primary cords [ADP, (ads), MP, (ABP)]; protoconch unknown. Operculum narrowly ovate with apical nucleus (Fig. 18J). Radula (Fig. 3F) of three-dimensional type with rachidian bearing moderately long, projecting, central cusp, with two narrow, short, lateral denticles, one on each side, long, narrow lateral cusp with short outer lateral denticle, and pronounced marginal cusp; lateral tooth narrow, sickle-shaped with broad base.

Distribution. Aleutian Islands, Alaska, living at 160-250 m.

Remarks. Warenia n. gen., a monotypic genus, strongly differs from two other, more or less similar genera in Trophoninae, Nipponotrophon and Scabrotrophon, in lacking their typical spiral cord morphology, Warenia having only numerous microscopic spiral striae on the convex part of teleoconch whorls, in having a very high spire, a very narrow, short siphonal canal and in having a very narrow subsutural ramp, only barely visible on first and second teleoconch whorls. Warenia differs from Boreotrophon (Pagodulinae), in which the type species was originally described by Dall (1907), in having a much narrower shell, with narrower, or an almost nonexistent subsutural band and by the different radula characters, Warenia having a rachidian, with typical pronounced marginal cusps, as observed in Trophoninae, but not in Pagodulinae.

Etymology. Named after Anders Warén (Natural History Museum, Stockholm) in acknowledgment for his help during so many years for radula preparation and SEM work of hundreds of radulae for the senior author.

\section{Ocenebrinae Cossmann, 1903}

The subfamily Ocenebrinae has historically been defined by shell morphology (Oldroyd 1927, Bormann 1946, Vokes 1964, 1971, Abbott 1974, Radwin \& D'Attilio 1976, Fair 1976, McLean 1978, 2007, Myers \& D’Attilio 1986, Kool 1993a, 1993b, Vermeij \& Vokes 1997), anatomy including operculum characteristics (Kool 1993a, 1993b) and by the radula (Vokes 1964, 1971, Radwin \& D'Attilio 1976, Kool 1993a, 1993b). Marko \& Vermeij (1999) and Barco et al. (2017) provided phylogenetic estimates of relationships among members of the subfamily. The three gene (COI + 16S + 28S) phylogeny constructed by Barco et al. (2017), analyzed 50 taxa from the diverse subfamily and summarized previously published historical literature. The subfamily contains 33 genera according to Barco et al. (2017) and 38 by the World Register of Marine Species (MolluscaBase 2018). Taxa are primarily restricted to temperate waters and are predators of plate limpets (Spight et al. 1974, Palmer 1988, Bertsch \& Rosas 2016), barnacles (Rice 1971, Abbott \& Haderlie 1980, McConnaughey \& McConnaughey 1985, Palmer 1988, McLean 1996, 2007; Merle et al. 2011, Bertsch \& Rosas 2016), mussels (McConnaughey \& McConnaughey 1985), chitons (Talmadge 1975, Abbott \& Haderlie 1980), other mollusks (Abbott \& Haderlie 1980, Palmer 1988, Merle et al. 2011) and shelled polychete worms (Palmer 1988). In general, most members have paucispiral protoconchs and sealed canals at maturity, most taxa with microsculpture consisting of scabrous fimbrations, with some members possessing, but not limited to, labral spines, internal denticles and elaborate, blade-like varices, traits helpful in determining certain genera. Although the Ocenebrinae operculum was defined as purpuroid by Vokes (1971), Barco et al. (2017) concluded this was not true across all taxa and the purpuroid characteristic was present in other subfamilies (Barco et al. 2017), suggesting this a possible convergent trait. Radwin \& D'Attilio (1976) detailed the typical Ocenebrinae radula with three rows of teeth, a rachidian tooth on each row, with two lateral teeth, rachidian base somewhat deep, rectangular, double endpoints strong and a thin, evident cowl maintaining the central cusp, four smaller sized cusps remain, intermediate cusps attached to laterals, which exhibit two to four denticles between each cusp and base of endpoint. Despite shell morphology, anatomical, radular and opercula characteristics being extremely useful tools in delimiting species, and often highly reliable, the study by Barco et al. (2017) was shown to support a non-conventional result, conflicting with more traditional morphological assessments, in particular, the use of Ocinebrina for both northeast Pacific and northeast Atlantic ocinebrinid groups. In an attempt to further stabilize nomenclature, a new genus is here described, with the work of Barco et al. (2017) used as a basis for other taxa recognized.

\section{Nucella Röding, 1798}

Type species. (SD Stewart 1927): Buccinum filosum Gmelin, 1791 [= Buccinum lapillus Linnaeus, 1758]. North Atlantic (see Kool \& Boss 1993). 
Diagnosis. Shell ovate to broadly fusiform; sculpture usually dominated by spiral cords, occasionally lamellose or nodose in some populations; outer lip crenulated at edge, without adapical notch or abapical sinus; columella without folds.

Remarks. Data from molecular sequences indicate that Nucella constitutes a distinct clade of temperate northern-hemisphere ocenebrine muricids (Collins et al. 1996, Marko et al. 2014). All species occur on rocky shores and, in the case of some northern populations, to a depth of $70 \mathrm{~m}$. All species drill hard-shelled prey including barnacles and bivalves, and some attack limpets and other gastropods. In the northeast Pacific we recognize eight species belonging to four groups: (1) the $N$. lima group, with $N$. lima (Gmelin, 1791) and $N$. angustior n. sp.; (2) the $N$. canaliculata group, with $N$. canaliculata (Duclos, 1832), N. analoga (Forbes, 1852) and N. compressa (Dall, 1915); (3) N. lamellosa (Gmelin, 1791); and (4) the N. emarginata group, with N. emarginata (Deshayes, 1839) and N. ostrina (Gould, 1852).

These groups are briefly characterized below:

Nucella lima group. Shell with low spire; last whorl rounded, without shoulder angulation, basally constricted to relatively long siphonal canal; axial sculpture absent; spiral sculpture consisting of 9-11 primary cords with secondaries between; aperture very broad; denticles on inner side of outer lip absent.

Nucella canaliculata group. Shell with relatively high spire; last whorl rounded, without shoulder angulation, basally weakly or not constricted to moderately long siphonal canal; sutures deep to channeled; axial sculpture absent; spiral sculpture consisting of nine or more closely spaced primary cords, typically with small secondary between; aperture relatively narrow; denticles on inner side of outer lip absent or very poorly expressed.

Nucella lamellosa group. Shell large, with high spire; last whorl with distinct shoulder angulation, basally constricted to long siphonal canal; axial sculpture lamellose, may be absent in some thick-shelled populations; spiral sculpture consisting of six or more high, widely separated primary cords, with secondaries between; aperture narrow; denticles on outer lip usually prominent.

Nucella emarginata group: Shell small for genus, with low spire; last whorl rounded, without shoulder angulation or basal constriction; siphonal canal very short; axial sculpture absent; spiral sculpture consisting of five or six widely spaced primary cords, secondaries between; aperture broad; denticles on outer lip prominent or absent.

\section{Nucella angustior new species}

(Figures 6A, 19A-B)

Type material. Monashka Bay, Kodiak Island, Alaska, leg. G.J. Vermeij, 24 June 1987, rocky intertidal zone, holotype LACM 3488, $29.8 \mathrm{~mm}$, lv.

Distribution. Southern Alaska east of the Aleutian Islands.

Description. Shell of moderate size for genus, maximum length $31.9 \mathrm{~mm}$, ovate, slightly constricted abapically; spire low, comprising 23 to $29 \%$ of total shell length. Teleoconch whorls rounded, not angulated at shoulder. Suture deeply impressed but not channeled. Axial sculpture absent except for squamose growth lines in uneroded specimens. Spiral sculpture consisting of high rounded primary cords, one smaller secondary cord between adjacent primary cords. First whorl with IP, P1, s1, P2, s2, second whorl with IP, P1, s1, P2, s2, starting adis, abis, P3, final whorl with adis, IP, abis, P1, t, s1, t, P2, t, s2, t, P3, s3, P4, s4, P5, s5, P6, t, s6, ADP, ads, MP, ABP. Aperture relatively narrow, ovate. Columellar lip narrow, adherent throughout length, smooth. Outer lip planar, very slightly produced abapically, thin, crenulated at edge, without sculpture on inner side. Siphonal canal short, widely open.

Remarks. Nucella angustior was long confused with $N$. lima (Gmelin, 1791) (Figs 6B, 19C-D), but molecular data (Cox et al. 2014) demonstrate that the two species are phylogenetically distinct while showing partial geographic overlap between the Aleutian Islands and northern Vancouver Island, and displaying overlapping morphological ranges. Compared to $N$. lima, $N$. angustior tends to have a higher spire, narrower aperture, and smaller maximum size. In $N$. lima, the spire comprises 9-25\% of total shell length, as compared with 23-29\% in N. angustior. Nucella angustior occurs in southern Alaska east of the Aleutian Islands, and may extend as far south as northern Vancouver Island. Nucella lima is distributed from the eastern Aleutian Islands westward to Kamchatka (Cox et al. 2014). In short, subtle, partially overlapping differences in shell 
morphology together with molecular differences and partially overlapping geographical ranges distinguish $N$. angustior and N. lima.

Etymology. Angustior (L), for narrower, referring to its shape in comparison with N. lima.

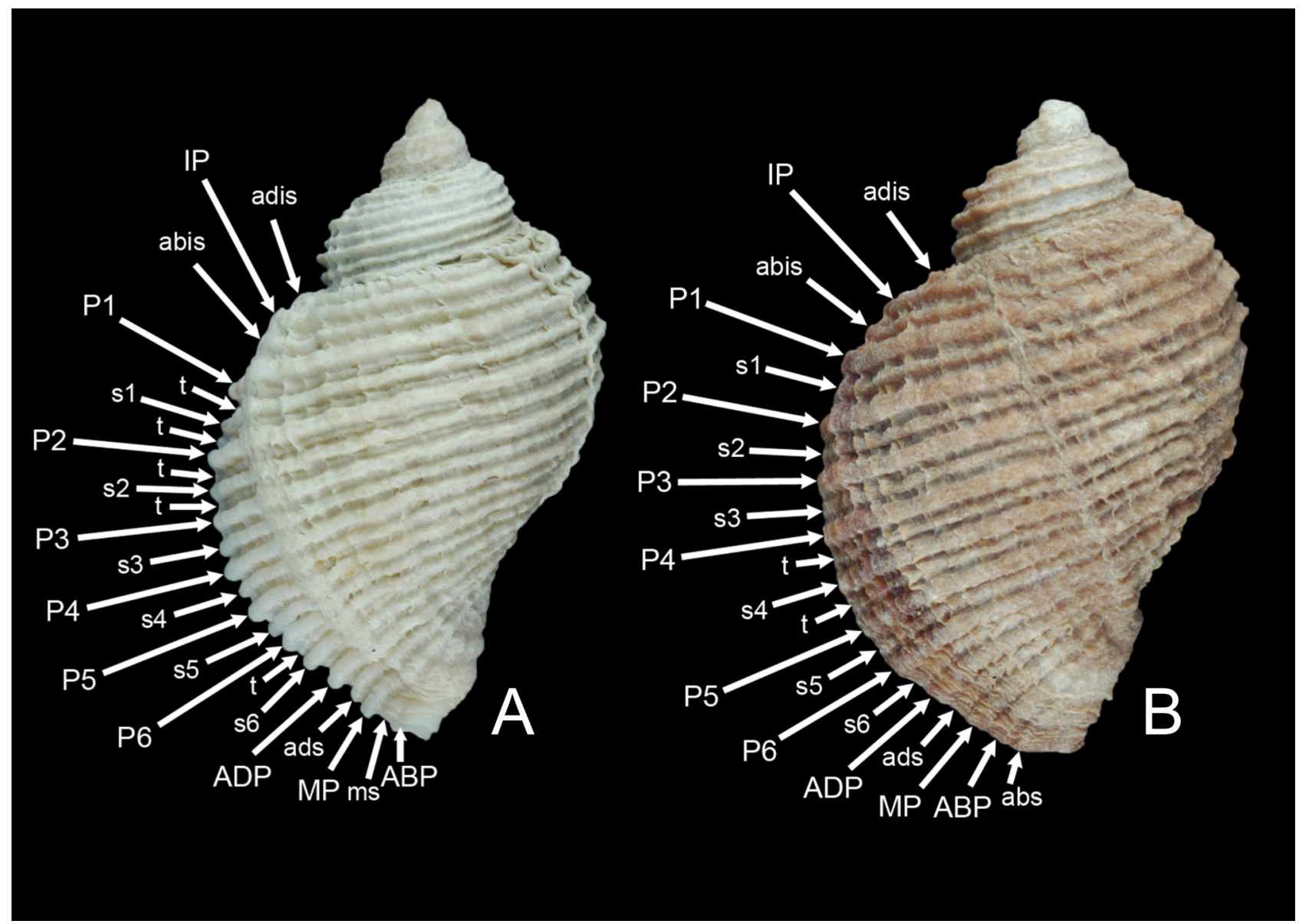

FIGURE 6. Spiral cords morphology of northeastern Pacific Muricidae. A. Nucella angustior n. sp. Monashka Bay, Kodiak Island, Alaska, holotype LACM 3488, 29.5 mm. B. Nucella lima (Gmelin, 1791). Mouth of Casco Cove, Attu Island, Aleutian Islands, Alaska, LACM 180337, $31.8 \mathrm{~mm}$.

\section{Paciocinebrina, new genus}

Type species. Tritonium luridum Middendorff, 1848: 244. Recent, Sitka, Alaska [two syntypes, ZISP 62131 (Fig. 20E-F)].

Description. Shell highly variable, most species small for the genus, several groups possessing morphologically recognizable characteristics, including teleoconch clathration, projecting spines, grotesquely inflated, tightly set, low laying cord sequences, indented sutures, often with series of subsutural cords. Protoconch tabulate, mostly carinate, sometimes smoother, teleoconch sculpture heavily scabrous, microstructure mostly consisting of vaulted scales, crispate fimbriations, siphonal canal sealed in most species. Absence of labral tooth, apertural denticles strong to weak, rarely absent, often with series of infrasutural cords.

Habitat. Species inhabit intertidal and subtidal rocky reefs and are associated with drilling barnacles, limpets and other gastropods. They are known from the temperate zone, mostly inhabiting shallow depths ( 0 $39 \mathrm{~m})$, several species residing in deeper habitats $(40-238 \mathrm{~m})$.

Remarks. Very few studies (Spight et al. 1974, Talmadge 1975, Palmer 1988) address the ecology and physiology of this northeast Pacific group. As seen with other gastropods (Deas 1971, Vance 1978, Forester 1979), and members of Muricidae in particular (Deas 1971, Wicksten, 1981), sponge associations are particularly common in several abundant species, including Paciocinebrina foveolata (Hinds, 1844), P. lurida 
(Middendorff, 1848) and P. munda (Carpenter, 1864). Morphologically, two genera, Ocenebra Gray, 1847 and Ocinebrina Jousseaume, 1880, have been confused and used for northeast Pacific members (Bormann 1946, Rice 1971, Abbott 1974, Fair 1976, Radwin \& D'Attilio 1976, McLean 1978, 2007, Turgeon et al. 1998, Marko \& Vermeij 1999, Houart \& Sirenko 2003, Houart 2011). In comparing Paciocinebrina protoconchs to illustrations by Myers \& D'Attilio (1986), of the northeast Atlantic, Ocenebra erinaceus (Linnaeus, 1758), type species of the genus, was shown to possess, at least, one extra protoconch whorl. Crocetta et al. (2012) figured and described protoconchs of several species of Ocinebrina, specifically, O. corallinoides (Pallary, 1912), O. reinai Bonomolo \& Crocetta, 2012 and the type species of the genus, O. aciculata (Lamarck, 1822). All species have a similar number of protoconch whorls compared to all Paciocinebrina spp. examined, except that Ocinebrina has a bulbous protoconch structure versus tabulate protoconch in all known Paciocinebrina spp. Phylogenetic analyses of mitochondrial and nuclear genes (COI $+16 \mathrm{~S}+28 \mathrm{~S})$ indicate the necessity to separate northeast Pacific members from the similar appearing northeast Atlantic clade, as northeast Pacific species are supported as more closely related to Nucella and Ocinebrellus Jousseaume, 1880 than to Atlantic groups (Barco et al. 2017).

Etymology. Named after the geographic affinity to the Pacific Ocean and the 'Ocinebrina' like morphology. Gender feminine.

\section{List of Recent Paciocinebrina species with their synonyms}

(bold: valid species)

Paciocinebrina atropurpurea (Carpenter, 1865)

= Tritonalia interfossa clathrata Dall, 1919

= Ocinebra rubra Baker, 1891

= Tritonalia tracheia Dall, 1919

P. barbarensis (Gabb, 1865)

= Tritonalia interfossa beta Dall, 1919

= Ocenebra keenae Bormann, 1946

$P$. benitoensis new species

P. circumtexta (Stearns, 1871)

= Ocinebra circumtexta aurantia Stearns, 1895

= Tritonalia circumtexta citrica Dall, 1919

= Tritonalia lurida rotunda Dall, 1919

P. crispatissima (Berry, 1953)

P. foveolata (Hinds, 1844)

= Tritonalia epiphanea Dall, 1919

= Tritonalia fusconotata Dall, 1919

P. fraseri (Oldroyd, 1920)

P. gracillima (Stearns, 1871)

= Tritonalia gracillima obesa Dall, 1919

= Ocinebra stearnsi Hemphill, 1911

P. grippi (Dall, 1911)

P. interfossa (Carpenter, 1864)

= Tritonalia interfossa alpha Dall, 1921

P. lurida (Middendorff, 1848)

= Vitularia aspera Baird, 1863

$P$. macleani new species

P. minor (Dall, 1919)

P. munda (Carpenter, 1864)

P. neobarbarensis new species

$P$. pseudomunda new species

P. seftoni (Chace, 1958)

P. sclera (Dall, 1919)

$=$ Coralliophila (Pseudomurex) kincaidi Dall, 1919 
Paciocinebrina barbarensis (Gabb, 1865)

(Figures 9G-I, 10A-C, 24A-J)

Type material. Murex (Muricidea) barbarensis Gabb, 1865: 183. Santa Catalina Island, Los Angeles County, California, $73.1 \mathrm{~m}$, lectotype (SD McLean 1996: 82), UCMP 10611, length $19.2 \mathrm{~mm}$, width $10.2 \mathrm{~mm}, 1 \mathrm{lv}$.

Tritonalia interfossa beta Dall,1919b: 250-251. Monterey, Monterey County, California, holotype USNM 46728, length $21.1 \mathrm{~mm}$, width $9.8 \mathrm{~mm}$.

Ocenebra keenae Bormann, 1946: 40-41, pl. 4., figs 17-18. White's Point, San Pedro, Los Angeles County, California, holotype CASIZ 064477, length $18.8 \mathrm{~mm}$, width $10.9 \mathrm{~mm}$.

Other material. Point Pinos, Pacific Grove, Monterey County, California, USNM 535946, 1 dd. Coho Reef, near Point Conception, Santa Barbara County, California, October 1974, on rocky reef at 7.6 m, SW 5, 2 dd. Point Conception, Santa Barbara County, California, March 1967, on bed rocks at $21 \mathrm{~m}$, LACM 11397, 1 dd. Canby Reef, Santa Barbara County, California, June 1970, on rubble at 12.1-30.4 m, SW 7, 1 dd. North Santa Monica, Los Angeles County, California, LACM 21871, 1 dd. White's Point, near San Pedro, Los Angeles County, California, LACM 72483, 1 lv. Point Fermin, near San Pedro, Los Angeles County, California, January 1959, LACM 151125, 1 dd. Point Fermin, near San Pedro, Los Angeles County, California, May 1960, LACM 11370, 5 dd. Point Fermin, near San Pedro, Los Angeles County, California, December 1960, LACM 61568, 2 dd. Point Fermin, near San Pedro, Los Angeles County, California, January 1961, LACM 11368, 1 dd. San Pedro, Los Angeles County, California, 1968, SW 8, 1 dd. Cabrillo Beach, near San Pedro, Los Angeles County, California, 1962, LACM 151124, 1 dd. Cabrillo Beach, near San Pedro, Los Angeles County, California, 1962, LACM 172868, 2 dd. Cabrillo Beach, near San Pedro, Los Angeles County, California, 1967, in tide pools, SW 9, 1 dd. Del Mar Beach, San Diego County, California $32^{\circ} 58^{\prime}$ 43.40" N, $117^{\circ} 16^{\prime} 21.14^{\prime \prime}$ W, 22 November 2002, in beach drift at -0.2 m tide, SW 10, 2 dd. Southeast of Cabo

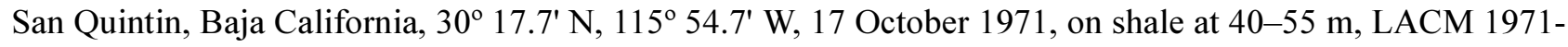
$150.29,5$ dd. off Punta Rompiente, Baja California Sur, $27^{\circ} 41.5^{\prime} \mathrm{N}, 115^{\circ} 05^{\prime} \mathrm{W}, 22$ October 1971, at $91 \mathrm{~m}$, LACM 1971-167.14, 1 dd.

Distribution. Known from Point Pinos, Monterey County, California $\left(36^{\circ} \mathrm{N}\right)$, to Punta Rompiente, Baja California $\operatorname{Sur}\left(27^{\circ} \mathrm{N}\right)$, intertidal to $91 \mathrm{~m}$, found in shallower water in the northern portion of the range, recorded deeper in southern localities.

Description. Shell small to extremely small, length $19.2 \mathrm{~mm}$, width $10.2 \mathrm{~mm}$ (lectotype), spire moderately acute, ribs bladelike, overall sculpture somewhat variable, specimens from northern portion of range typically having more upward projecting spines. Spiral cords scabrous, more prominent in tertiary cords. Shape rhomboid ovate, some specimens slender, shell thick, color occasionally variable, primarily dark brown, occasionally tan, rarely with brown band on base of final whorl. Protoconch initially bulbous, slight keel rapidly developed, initial teleoconch whorls with two large cords, quickly countered by thin, scabrously bladed ribs, tightly set, transitioning to subtle clathrations. First, second whorl with P1, P2, third whorl with P1, P2, starting s1, s2, fourth whorl with P1, s1, P2, s2, starting IP, final whorl with adis, IP, abis, P1, t, s1, t, P2, s2, P3, s3, P4, s4, P5, s5, P6, ADP, MP, ABP. Spiral cords variable in strength and size. Denticle morphology D1-D5. Aperture small, elongate ovate, lip extremely thick, scabrous, parietal wall very thick throughout, denticles moderate to wanting, siphonal canal very thick, somewhat short in length.

Remarks. This species is quite variable and has two forms along the coastline. The more typical, larger form ranges from Point Pinos, Monterey County, California, to Punta Rompiente, Baja California Sur, with specimens from Monterey to Santa Barbara tending to exhibit long projecting shoulder spines at rib intersections, specimens south of this range primarily with rounded shoulders. A miniature, primarily deeper water form, from cooler waters has been consistently recorded from Big Sur, Monterey County, California $\left(36^{\circ} \mathrm{N}\right)$, to the outer California Channel Islands (Buck 1989), reappearing in the upwelling region of northern Baja California. These specimens are very similar in spiral morphology and are here considered conspecific. Due to the similarities in spiral morphology, Ocenebra keenae Bormann, 1946, is here regarded as a junior synonym. Until further samples of these forms are collected, and a molecular analysis is conducted, this interpretation remains speculative. 


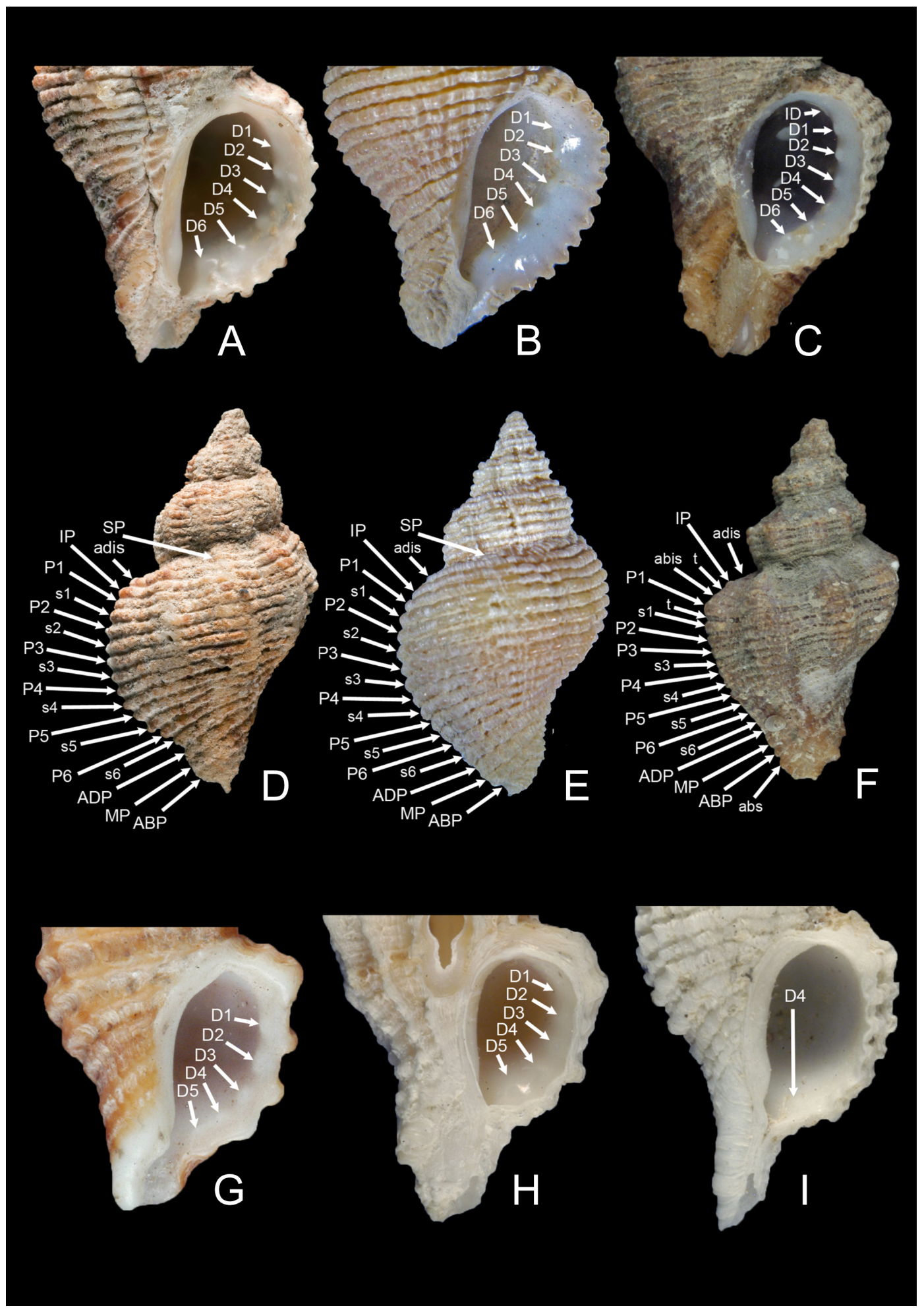

FIGURE 7. Spiral cords and apertural denticles morphology of northeastern Pacific Muricidae. A, D. Paciocinebrina lurida (Middendorff, 1848). Vancouver Island, British Columbia, Canada, syntype of Vitularia aspera Baird, 1863, NHMUK 1863.2.4.10/1, 23.0 mm (photo Harry Taylor, NHMUK Photographic Unit, @ Natural History Museum of London). B, E. Paciocinebrina lurida (Middendorff, 1848). Sitka, Sitka County, Alaska, syntype of Tritonium luridum Middendorff, 1848, ZISP 62131, 18.0 mm. C, F. Paciocinebrina foveolata (Hinds, 1844). Cabrillo Beach, Los Angeles County, California, $33^{\circ} 42^{\prime}$ $16.6^{\prime \prime} \mathrm{N}, 118^{\circ} 15^{\prime} 50.1^{\prime \prime} \mathrm{W}$, intertidal, hypotype NHMUK 20170344, $18.5 \mathrm{~mm}$. G. Paciocinebrina atropurpurea (Carpenter, 1865). Neah Bay, Clallam County, Washington, $48^{\circ} 22^{\prime} 40^{\prime \prime} \mathrm{N}, 124^{\circ} 36^{\prime} 52^{\prime \prime} \mathrm{W}$, holotype USNM $15528 \mathrm{~B}, 13.7 \mathrm{~mm} . \mathrm{H}$. Paciocinebrina macleani n. sp. Caleta Melpomeme, Guadalupe Island, Baja California, $28^{\circ} 52.13^{\prime} \mathrm{N}, 118^{\circ} 15.98^{\prime} \mathrm{W}, 92 \mathrm{~m}$, holotype LACM 3049, 11.2 mm. I. Paciocinebrina thelmacrowae n. sp. Todos Santos Island, near Ensenada, Baja California, $31^{\circ} 50^{\prime} \mathrm{N}, 116^{\circ} 45^{\prime} \mathrm{W}, 18-45 \mathrm{~m}$, holotype LACM 2712, $10.7 \mathrm{~mm}$. 


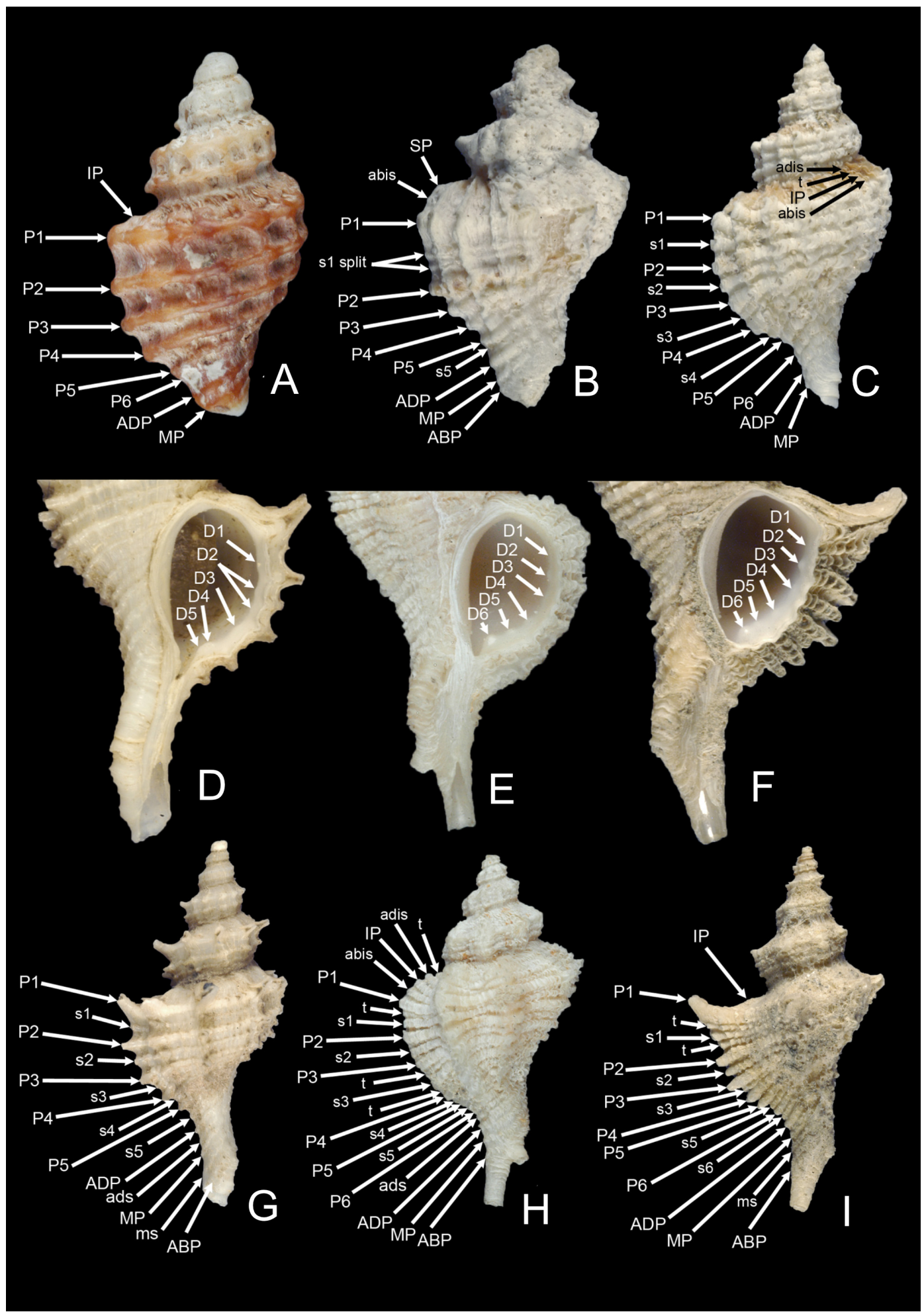

FIGURE 8. Spiral cords and apertural denticles morphology of northeastern Pacific Muricidae. A. Paciocinebrina atropurpurea (Carpenter, 1865). Neah Bay, Clallam County, Washington, 48 ${ }^{\circ} 22^{\prime} 40^{\prime \prime} \mathrm{N}, 124^{\circ} 36^{\prime} 52^{\prime \prime} \mathrm{W}$, holotype USNM 15528B, 13.7 mm. B. Paciocinebrina macleani n. sp. Caleta Melpomeme, Guadalupe Island, Baja California, 28 ${ }^{\circ} 52.13^{\prime} \mathrm{N}$, $118^{\circ} 15.98^{\prime} \mathrm{W}, 92 \mathrm{~m}$, holotype LACM 3049, $11.2 \mathrm{~mm}$. C. Paciocinebrina thelmacrowae n. sp. Todos Santos Island, near Ensenada, Baja California, $31^{\circ} 50^{\prime} \mathrm{N}, 116^{\circ} 45^{\prime} \mathrm{W}, 18-45 \mathrm{~m}$, holotype LACM 2712, $10.7 \mathrm{~mm}$. D, G. Paciocinebrina benitoensis n. sp. $8.8 \mathrm{~km}$ south of San Benito Island, Baja California, $28^{\circ} 13.2^{\prime} \mathrm{N}, 115^{\circ} 33.4^{\prime} \mathrm{W}, 126-144 \mathrm{~m}$, holotype LACM $3082,14.7$ mm. E, H. Paciocinebrina crispatissima (Berry, 1953). Off Isthmus Cove, Santa Catalina Island, Los Angeles County, California, R/V ZACA, $60.3 \mathrm{~m}$, holotype CASIZ 064468, $20.6 \mathrm{~mm}$. F, I. Paciocinebrina neobarbarensis $\mathbf{n}$. sp. $3.2 \mathrm{~km}$ southeast of Long Point, Santa Catalina Island, Los Angeles County, California, 33 22.0' N, $118^{\circ} 30.3^{\prime} \mathrm{W}, 86 \mathrm{~m}$, holotype LACM 3497 , $19.9 \mathrm{~mm}$. 


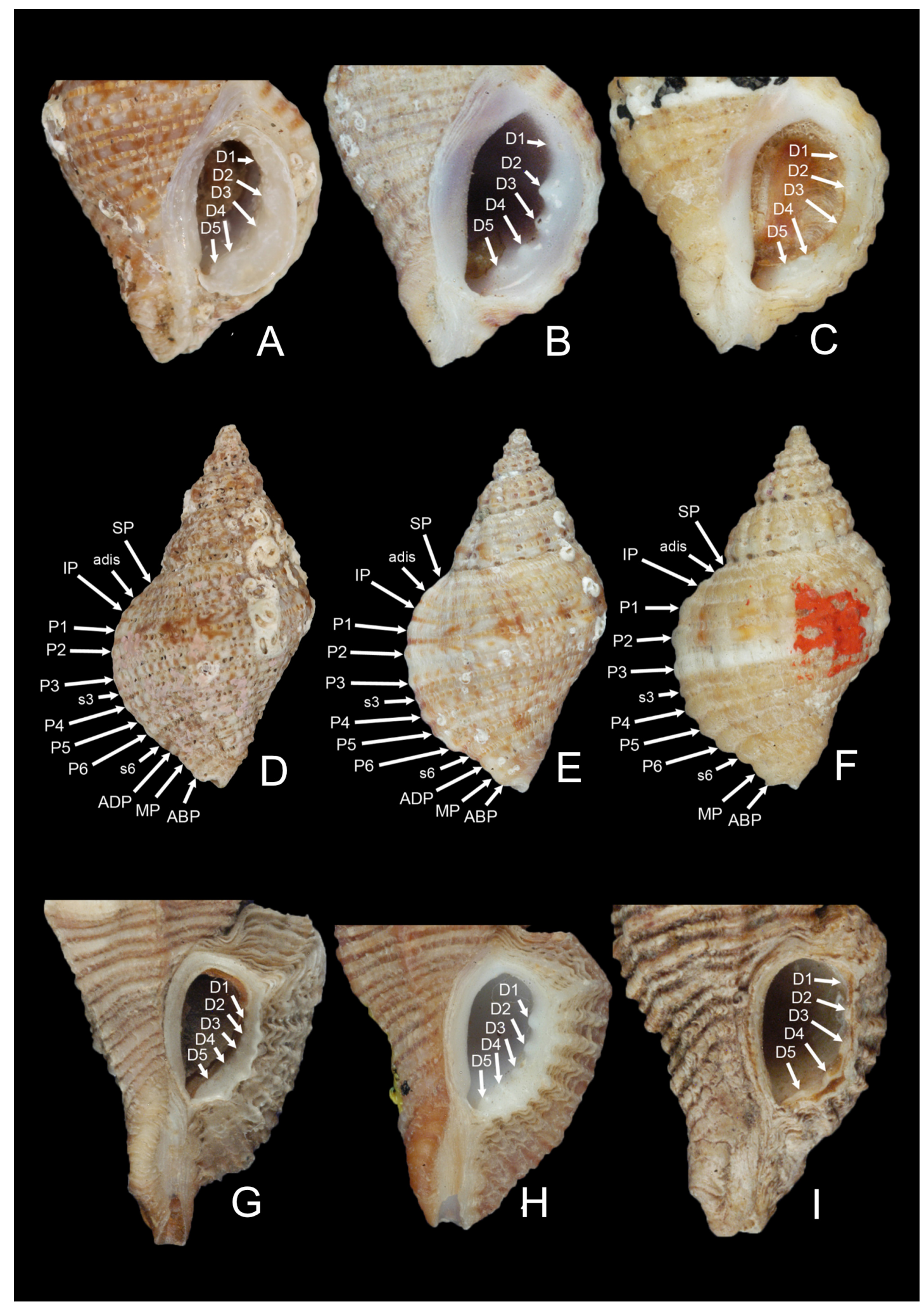

FIGURE 9. Spiral cords and apertural denticles morphology of northeastern Pacific Muricidae. A-F. Paciocinebrina gracillima (Stearns, 1871). A, D. San Diego, San Diego County, California, at $18.2 \mathrm{~m}$, syntype of Ocinebra gracillima Stearns, 1871, USNM 46920, 13.3 mm. B, E. Laguna Beach, Orange County, California, holotype of Paciocinebrina obesa (Dall, 1919), USNM 228722, 13.8 mm. C, F. Monterey Bay, Monterey County, California, syntype of Ocinebra stearnsi Hemphill, 1911, CASIZ 058824, 12.5 mm. G-I. Paciocinebrina barbarensis (Gabb, 1865). G. Santa Catalina Island, Los Angeles County, California, $73.1 \mathrm{~m}$, lectotype of Murex (Muricidea) barbarensis Gabb, 1865, UCMP 10611, 19.2 mm. H. White's Point, San Pedro, Los Angeles County, California, holotype of Ocenebra keenae Bormann, 1946, CASIZ 064477, 18.8 mm. I. Monterey Bay, Monterey County, California, holotype of Paciocinebrina beta (Dall, 1919), USNM 46728, $21.1 \mathrm{~mm}$. 
Dall's (1921) illustration of what he considered P. barbarensis (Gabb, 1865) is here regarded as $P$. neobarbarensis n. sp. (Figs 8F, I, 23G-H), a circumstance, which resulted in a long-standing confusion about this species identity. The superficially similar species are separated by their size, shape, habitat and spiral morphology with $P$. barbarensis having adis, abis, the absence of $\mathrm{t}$ cord after P1, s6 and ms cord after MP (Fig. 10A) in comparison to P. neobarbarensis (Fig. 8I). Specimens of P. neobarbarensis are found at greater depths, are thinner in composition, have projecting ribs on last whorl, commonly with no projections prior, are much more slender, the spire is more acute, is overall taller, and the siphonal canal is thinner and longer. Paciocinebrina foveolata (Hinds, 1844) is also comparable to P. barbarensis but is larger in size, has less exaggerated projections at ribs, spines absent, more denticles, less scabrous in sculpture, cords weaker (Figs 21G-L, 22C-D), with additional t cord after IP, s4, s6 and abs after ABP (Fig. 7F), P. barbarensis with additional $t$ cord after s1 and s2 (Fig. 10A), D6 absent (Fig. 9G). Paciocinebrina fraseri (Oldroyd, 1920) is comparable to $P$. barbarensis, but has $\mathrm{s} 4$ and ads, lacking abis, two t cords, one after P1 and another after P6 (Fig. 10G) compared to P. barbarensis (Fig. 10A). The shell of $P$. fraseri is overall more slender, elongate in shape and has a narrower and longer siphonal canal. The species epithet barbarensis is especially appropriate as the species is most commonly found in the Santa Barbara area.

\section{Paciocinebrina benitoensis new species}

(Figures 8D, G, 23C-F)

Type material. Holotype: $8.8 \mathrm{~km}$ south of San Benito Islands, Baja California ( $\left.28^{\circ} 13.2^{\prime} \mathrm{N}, 115^{\circ} 33.4^{\prime} \mathrm{W}\right), \mathrm{R} /$ V Velero III 1251-41, 26 February 1941, on coarse and fine sand at 126-144 m holotype LACM 3082 (ex LACM 1941-31.25), length $14.7 \mathrm{~mm}$, width $6.8 \mathrm{~mm}, 1 \mathrm{lv}$.

Distribution. Known only from vicinity of San Benito Islands, Baja California, 126-174 m.

Description. Shell extremely small for genus, tall, narrow, elongate, whorls rotund, peripheral cords projecting into spines, shell somewhat thin, length to $14.7 \mathrm{~mm}$, width $6.8 \mathrm{~mm}$ (holotype). Protoconch characteristically tabulate, slightly rounded, somewhat loosely coiled, tabulate, subtly rotund at periphery, carination wanting, spire tall, whorls elevated. Teleoconch sculpture of very fine scabrous growth lines overriding thick primary cords, remarkably round, stronger at periphery, projecting at each rib intersection, hollow spines at rib intersections, peripheral spines upturned, anteriorly cords project outward, cord sequences variable, shoulder tabulate but rotund in profile, suture impressed, color off white, semi-transparent between cords on final whorl. First whorl with P1, P2, second whorl with P1, P2, starting s2, third whorl with P1, P2, s2, starting P3, fourth whorl with P1, P2, s2, P3, starting s1, final whorl with P1, s1, P2, s2, P3, s3, P4, (s4), P5, (s5), ADP, ads, MP, ms, ABP. Aperture large, round, slightly ovate, outer lip relatively thickened, with heavy growth scabrations, columellar lip thick, smooth and protruding, slightly wider at base, twisted anteriorly. Denticles decreasing progressively in strength anteriorly with D1, D2 split, D3, D4, D5. Siphonal canal thin yet robust, width relatively broad, canal extraordinarily long, twice bent. Operculum ovate, thin, pointed at anterior end.

Remarks. Compared to P. neobarbarensis (Figs 8F, I, 23G-H). P. benitoensis (Figs 8D, G, 23C-F) is much smaller in size, has a more rounded whorl profile, less projecting spines, maintains a more slender shape, primary cords are more upwardly projected and prominent, secondary cords are much more subtle, the whorl profile is more rotund, the suture is more indented, and the shell is overall thinner. Both species inhabit deep waters but $P$. benitoensis is presumed to be endemic to the San Benito Islands, Baja California.

Etymology. Named after the San Benito Islands, Baja California, where the type specimens were collected.

\section{Paciocinebrina foveolata (Hinds, 1844)}

(Figures 7C, F, 21G-L, 22C-D)

Type material. Murex foveolatus Hinds, 1844a: 127. Type locality: Bahia Magdalena, Baja California Sur, type material missing. Cabrillo Beach, San Pedro, Los Angeles County, California (33 ${ }^{\circ} 42^{\prime} 16.6^{\prime \prime} \mathrm{N}, 118^{\circ} 15^{\prime}$ $50.1 " \mathrm{~W}), 11$ February 2014, on rocks at $-0.52 \mathrm{~m}$ low tide, hypotype NHMUK 20170344, length $18.5 \mathrm{~mm}$, width $9.3 \mathrm{~mm}$.

Tritonalia fusconotata Dall, 1919a: 333-334, Monterey Harbor, Monterey County, California, holotype, USNM 46729, length $25.0 \mathrm{~mm}$, width $14.0 \mathrm{~mm}$. 
Tritonalia epiphanea Dall, 1919a: 335, San Pedro, Los Angeles County, California, holotype, USNM 216809 , length $24.1 \mathrm{~mm}$, width $11.0 \mathrm{~mm}$.

Other material. Carmel Submarine Canyon, north end of San Jose Creek Beach, Monterey County, California, 36 $32^{\prime} \mathrm{N}, 121^{\circ} 56^{\prime} \mathrm{W}, 1960-1964$, on rock and Macrocystis, 12-38 m, LACM 1960-24, 5dd. Off

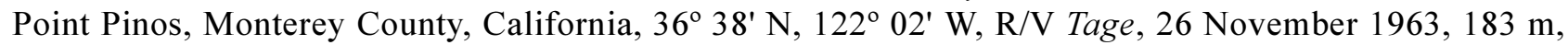
LACM 1963-52.6, 1 dd. Exposed side of Coast Guard breakwater, Monterey, Monterey County, California, $36^{\circ} 36.5^{\prime} \mathrm{N}, 121^{\circ} 53.4^{\prime} \mathrm{W}, 14$ July 1973 , on gravel and mud, 8-12 m, LACM 1973-12.21, 1 lv. Off Del Monte,

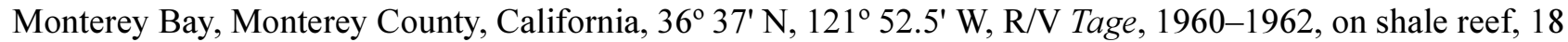
m, LACM 1960-22.30, 1 dd. West of Cayucos Creek, north of Cayucos, San Luis Obispo County, California, $35^{\circ} 26.8^{\prime} \mathrm{N}, 120^{\circ} 54.5^{\prime} \mathrm{W}, 11$ December 1977, intertidal on shale ledges, LACM 1977-112, 4 dd. Morro Bay, San Luis Obispo County, California, May 1966, 21 m, LACM 151129, 1 dd. Shell Beach, San Luis Obispo County, California, $35^{\circ}$ 09.4' N, $120^{\circ} 40.6^{\prime} \mathrm{W}, 1961-1963$, intertidal, on shale ledges, LACM 1961-11.47, 6 dd. Point Conception, Santa Barbara County, California, Aug 1966, on rocks, 18 m, LACM 61595, 1 dd. South side of Government Point, south of Point Conception, Santa Barbara County, California, $34^{\circ} 26.5^{\prime}$ N, $120^{\circ} 27^{\prime} \mathrm{W}$, on rocks, 12-15 m, LACM 1963-38.17, 1 lv. Coho Point, Hollister Ranch, Santa Barbara County, California, 1967, on silt and rubble, 24 m, LACM 61660, 1 dd. Wilson Rock, San Miguel Island, Santa Barbara County, California, 34 06.4' N, $120^{\circ} 23.7^{\prime} \mathrm{W}, 31$ May 1982, on granite pinnacles, 23-27 m, LACM 1982-59.27, 1 dd. Adam's Cove, San Miguel Island, Santa Barbara County, California, 3 August 1965, on Haliotis, 34 m, LACM 11417, 1 dd. Alcott Shoals, Santa Rosa Island, Santa Barbara County, California, 6 August 1966, on rocks, 15 m, LACM 61438, 1 dd. Point Fermin, San Pedro, Los Angeles County, California, May 1960, intertidal, LACM 55938, 1 dd. Point Fermin, San Pedro, Los Angeles County, California, May 1960, LACM 61578, 1 dd. San Pedro, Los Angeles County, California, LACM 59605, 1 dd. San Pedro, Los Angeles County, California, LACM 61576, 1 lv. Off Willow Cove, Santa Catalina Island, Los Angeles

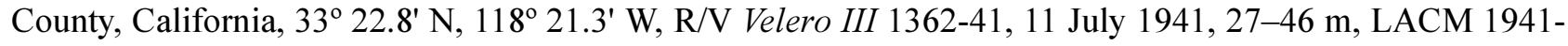
142.9, 1 dd. San Clemente Island, Los Angeles County, California, 1968, on Haliotis, 18 m, LACM 11488, 1 dd. Laguna Beach, Orange County, California, LACM 151116, 1 dd. San Diego Bay, San Diego County, California, 1966, on mud and cobbles with dense red algae, 15 m, LACM 150880, 1 lv. Imperial Beach, San Diego County, California, November 1940, LACM 151131, 2 dd. Puerto Arbolito, south side of Punta Banda, western Baja California, 31 ${ }^{\circ} 43^{\prime} \mathrm{N}, 116^{\circ} 42^{\prime} \mathrm{W}, 6$ October 1968, 17-20 m, LACM 1968-40.25, 1 lv. $100 \mathrm{~m}$

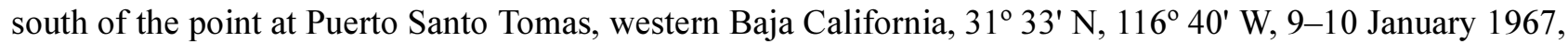
3-8 m, LACM 1967-1.45, 1 dd. Kellett Channel, south of Cedros Island, Baja California, 27 $57^{\prime} \mathrm{N}, 115^{\circ} 08.5^{\prime}$ $\mathrm{W}, R / V$ Searcher, 20 October 1971, on pebbles and shale, $37 \mathrm{~m}$, LACM 1971-159.35, $1 \mathrm{dd}$.

Distribution. Known from Monterey County, California $\left(36^{\circ} \mathrm{N}\right)$, to the type locality, Magdalena Bay, Baja California $\left(24^{\circ} \mathrm{N}\right)$.

Description. Shell small to relatively large sized, length $18.4 \mathrm{~mm}$, width $9.9 \mathrm{~mm}$ (Figs 22C-D), extremely variable in sculpture and size from one locality to another. Generally thick shelled with fine cords interrupted by incised lines, northern specimens more scabrous, southern specimens occasionally more elongate in shape. General shape rhomboid, color light tan to dark brown, occasionally with brown or light-colored bands or dark lines near periphery, siphonal canal usually lighter in color. Spire moderately tall, protoconch slightly worn in hypotype (Fig. 22C-D), teleoconch sculpture with strong, tightly spaced ribs, peripheral cord projecting in early whorls, scabrous sculpture evident in interspaces between cords, cords overriding ribs, thin but strong in initial whorls, progressively thicker, wide on final whorls, extremely subtle on subsutural ramp, siphonal canal wide, somewhat short in length. Spiral cords wide and flattened, relatively consistent throughout, interspace appears pitted by moderately spaced scabrous keels, subsutural ramp cords insignificant. First whorl with IP, P1 and P2, second with IP, P1 and P2, starting adis, abis and P3, third with adis, IP, abis, P1, P2 and P3, starting s1 and s3, fourth with adis, IP, abis, P1, s1, P2, P3, s3, starting P4; last whorl with adis, IP, t, abis, P1, t, s1, P2, P3, s3, P4, s4, P5, s5, P6, s6, ADP, MP, ABP, abs. Width of primary, secondary cord size, strength variable in final whorl. Denticle morphology with ID, D1, D2, D3, D4, D5, D6. Aperture ovate, somewhat small, outer lip very thick, parietal wall moderate with seven moderate denticles on outer lip.

Remarks. Phenotypic plasticity has likely contributed to conflicting views of diversity of this species, resulting in opposed perspectives ranging from those who lumped nominal species (Abbott 1974, Radwin \& D'Attilio 1976) and those who split taxa (Fair 1976, McLean 1978, 2007). Our understanding of the name foveolata is based on the original Latin description (Hinds 1844a) and the subsequent illustration by Hinds 
(1844b: 9, pl. 3, figs 15-16). Keen (1966) was unsuccessful in locating the holotype from Magdalena Bay, Baja California, in a search for the Hinds types, and a recent inquiry to Andreia Salvador (NHMUK) was additionally unsuccessful. The specimen figured here (Fig. 22C-D) from Cabrillo Beach, California represents a typical form that matches the description and original illustration of this species (Figs $21 \mathrm{~K}-\mathrm{L}$ ). This illustration and description were not detailed enough to acertain the exact spiral morphology, which brings to question the validity of both Tritonalia fusconotata Dall, 1919 (Fig. 21I-J) and T. epiphanea Dall, 1919 (Fig. $21 \mathrm{G}-\mathrm{H})$. Until further molecular or morphological data supports an alternative, these species are here synonymized and are thought to display typical morphological variation within this species.

Paciocinebrina foveolata is similar to P. grippi (Dall, 1911) (Fig. 21E-F) and P. crispatissima (Berry, 1953) (Figs 8E, H, 23I-J). Paciocinebrina grippi is distinctive in sculpture with subtle cords, giving a smooth appearance, a short, flattened spire, eight apertural denticles ( 6 in foveolata), with $\mathrm{t}$ and abis reversed, absence of $t$ after $\mathrm{P} 1$ and the presence of $\mathrm{t}$ after $\mathrm{P} 2$, s2 and ads. Paciocinebrina crispatissima has an extremely long siphonal canal, a projecting peripheral cord at ribs throughout teleoconch whorls, sometimes additional cords anteriorly, lacks an infrasutural denticle, (Figs 7C, 8E) and has a different spiral cord morphology (Figs 7F, $8 \mathrm{H}$ ) with three additional $\mathrm{t}$ cords, one before adis, one before and one after s3, and lacks $t$ after $\mathrm{s} 1$.

\section{Paciocinebrina gracillima (Stearns, 1871)}

(Figures 9A-F, 25C-J)

Type material. Ocinebra gracillima Stearns, 1871: 1. San Diego, San Diego County, California, at $18.2 \mathrm{~m}$, syntype, USNM 46920, length $13.3 \mathrm{~mm}$, width $7.4 \mathrm{~mm}, 1 \mathrm{lv}$.

Tritonalia gracillima obesa Dall, 1919a: 333. Laguna Beach, Orange County, California, holotype, USNM 228722, length $13.8 \mathrm{~mm}$, width $8.0 \mathrm{~mm}, 1 \mathrm{dd}$.

Ocinebra stearnsi Hemphill, 1911: 100-101. Monterey Bay, Monterey County, California, syntype, CASIZ 058824, length $12.5 \mathrm{~mm}$, width $7.6 \mathrm{~mm}, 1$ lv. Syntype CASIZ 223328, length $12.8 \mathrm{~mm}, 7.2 \mathrm{~mm}, 1 \mathrm{lv}$.

Other material. Monterey, Monterey County, California, LACM 59532, 2 dd. Monterey, Monterey County, California, LACM 59472, 4 dd. Carmel Bay, Monterey County, California, LACM 59496, 3 dd. West of Cayucos Creek, near Cayucos, San Luis Obispo County, California, 35 ${ }^{\circ} 26.8^{\prime} \mathrm{N}, 120^{\circ} 54.5^{\prime} \mathrm{W}, 11$ December 1977, intertidal on shale ledges and boulder reef, LACM 1977-112, 1 dd. Near Arroyo Grande, San Luis Obispo County, California, LACM 59520, 2 dd, 1 lv. Northwest side of San Miguel Island, Santa Barbara County, California, 34 03.3' N, 120 25.5' W, 29-31 May 1982, on rocky ledges, 9-14 m, LACM 1982-58.39, 2 dd. Smugglers Cove, Santa Cruz Island, Santa Barbara Coumty, California, 24 January 1963, 21 m, LACM 59513, 1 dd. Anacapa Passage, west of Anacapa Island, Ventura County, California, 33 59.0' N, $119^{\circ} 32.1^{\prime} \mathrm{W}$, R/V Velero III 1190-40, 30 October 1940, in sand and gravel, 27-91 m, LACM 1940-164.19, 1 dd. Malibu, Los Angeles County, California, 17 June 1936, LACM 70624, 13 dd, 5 lv. Flatrock Point, and Bluff Cove, Palos Verdes Peninsula, Los Angeles County, California, 33 47.8' N, $118^{\circ} 24.5^{\prime}$ W, 24-26 December 1962, intertidal on rocks, LACM 1962-21.26, 11 dd, 6 lv. White's Point, near San Pedro, Los Angeles County,

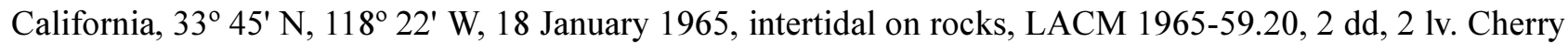
Cove, west of Isthmus Cove, Santa Catalina Island, Los Angeles County, California, 33 $27^{\prime} \mathrm{N}, 118^{\circ} 30^{\prime} \mathrm{W}, \mathrm{R} /$ V Velero IV 1623-48, 30 October 1948, intertidal on protected shore, LACM 1948-15.14, 1 dd. Long Point, Santa Catalina Island, Los Angeles County, California, 33 ${ }^{\circ} 24.3^{\prime} \mathrm{N}, 118^{\circ} 21.8^{\prime} \mathrm{W}, \mathrm{R} / \mathrm{V}$ Velero IV 1646-48, 30 November 1948, intertidal on rocky headland, LACM 1948-30.6, 1 dd. Laguna Beach, Orange County, California, 16 July 1923, LACM 19905, 9 dd, 2 lv. China Point, San Clemente Island, Los Angeles County, California, $32^{\circ} 48^{\prime} \mathrm{N}, 118^{\circ} 25.5^{\prime} \mathrm{W}, 11$ November 1939, intertidal, LACM 1939-2.7, 1 dd. La Jolla, San Diego County, California, 32 ${ }^{\circ} 50^{\prime} \mathrm{N}, 117^{\circ} 20^{\prime} \mathrm{W}, 16$ March 1954, in kelp beds, LACM 59627, 2 dd. Foot of Midway Street, La Jolla, San Diego County, California, $32^{\circ} 48.5^{\prime} \mathrm{N}, 117^{\circ} 16.0^{\prime} \mathrm{W}, 9$ December 1962, intertidal, LACM 1962-17.31, 1 dd. San Diego, San Diego County, California, 1925-1929, LACM 18086, 15 dd, 8 lv. Todos Santos Bay, $0.8 \mathrm{~km}$ past La Jolla Trailer Park, north side of Punta Banda, Baja California, $31^{\circ} 43.5^{\prime} \mathrm{N}, 116^{\circ} 41^{\prime}$ W, 8 Jan 1966, intertidal, LACM 1966-4.22, 2 dd. West Anchorage, Guadalupe Island, Baja California, $28^{\circ}$ 58.5' N, $118^{\circ} 18^{\prime} \mathrm{W}$, October 1965, 6 m, LACM 1965-41.16, 2 dd. South Anchorage, Guadalupe Island, Baja California,, $28^{\circ} 53.5^{\prime} \mathrm{N}, 118^{\circ} 16^{\prime} \mathrm{W}$, October 1965, 15-37 m, LACM 1965-42.26, $1 \mathrm{lv}$.

Distribution. Known from Moss Beach, San Mateo County, California $\left(37^{\circ} \mathrm{N}\right)$, to Punta Banda, Baja California $\left(31^{\circ} \mathrm{N}\right)$; Guadalupe Island, Baja California $\left(28^{\circ} \mathrm{N}\right)$.

Description. Shell extremely small, rhomboid shaped, spire tall to moderately tall, canal short, whorls 
rotund, shell thick, ribs, cords primarily of equal strength, some specimens with squarish pits at interspaces, length $13.3 \mathrm{~mm}$, width $7.4 \mathrm{~mm}$ (syntype). Protoconch large, bulbous, flattened, slightly projecting to one side. Teleconch whorls initially cancellate, progressing anteriorly, increasingly scabrous, squarish pits more defined in final whorl. Specimens found in northern portion of range usually more clathrate with deeper pits. First whorl with P1, P2, second, third whorl with P1, P2, starting IP, fourth whorl with IP, P1, P2, starting s1, P3, last whorl with SP, adis, IP, P1, P2, P3, s3, P4, P5, P6, s6, ADP, MP, ABP. Spiral cord similar in strength, size, northern specimens usually with thicker cords. Denticle morphology with D1, D2, D3, D4, D5. Aperture elongate, ovate, large, outer lip very thick, columellar lip wide, siphonal canal short, truncated, wide. Operculum ovate, pointed anteriorly, dark brown, centrally lighter in color.

Remarks. Stearns's (1871) original description of Ocinebra gracillima from San Diego, California was reported to have been collected at $18.2 \mathrm{~m}$ depth, by H. Hemphill. Three lots located by Ellen Strong, from the National Museum (USNM 46695, USNM 46696, USNM 46920), provided less insight into the correct type specimens designated by Stearns, as labels only contained portions of the full data. Stearn's (1871) description may have been based on a collation of data from these lots found from the San Diego area, leaving type material for this species ambigious. A lectotype designation selected from lots speculated to have been originally reviewed by Stearns is non-compliant with ICZN Article 74.1. Therefore, more information and/or material is needed to decide the authenticity of possible syntypes prior to a lectotype designation for this species. We here illustrate a specimen from USNM, which matches the original description of $P$. gracillima, and has several components of data provided by Stearns in his original description. The species, $P$. gracillima, is unique in that it is not comparable to other eastern Pacific species with the rotund shape, thick shell and unique coloration.

Several other nominal taxa, P. obesa (Dall 1919a, 1921, Oldroyd 1927, Keen 1937, Burch 1945, Fair 1976, Goto \& Poppe 1996) and P. stearnsi (Hemphill 1911, Dall 1921, Oldroyd 1927, Keen 1937, Burch 1945, Fair 1976, Goto \& Poppe 1996), were never figured and have been used to identify specimens from Laguna Beach, California, and a light, yellow colored form from Monterey, California, respectively. Both proposed taxa match the variability within $P$. gracillima, and are here considered junior synonyms.

\section{Paciocinebrina lurida (Middendorff, 1848)}

(Figures 7A-B, D-E, 20A-J, 21A-D)

Type material. Tritonium luridum Middendorff, 1848: 244. Sitka, Sitka County, Alaska, two syntypes ZISP 62131, length $18.0 \mathrm{~mm}$ and $17.5 \mathrm{~mm}$.

Vitularia aspera Baird, 1863: 66, Vancouver Island, British Columbia, Canada, syntype, NHMUK 1863.2.4.10/1, length $23.0 \mathrm{~mm} ; 8$ syntypes NHMUK 1863.2.4.10/2-9.

Other material. Seldovia Point, north coast Kenai Peninsula, Kachemak Bay, Cook Inlet, Kenai-Cook Inlet County, Alaska, 59 ${ }^{\circ} \mathrm{N}, 151^{\circ} \mathrm{W}, 1969,0-18 \mathrm{~m}$, LACM 1969-67.25, 3 dd. Forrester Island, Prince of Wales-Outer Ketchikan County, Alaska, 1914, LACM 59536, 1 dd. Mackaye Harbor, southwest end of Lopez Island, San Juan Islands, San Juan Island County, Washington $48^{\circ} 26^{\prime} \mathrm{N}, 122^{\circ} 53^{\prime} \mathrm{W}, 20$ June 1966, intertidal, LACM 1966-39.20, 1 dd. Salmon Point, Mendocino County, California, 39 $12.8^{\prime} \mathrm{N}, 123^{\circ} 46.5^{\prime} \mathrm{W}, 10$ June 1949, intertidal on rocks, LACM 1949-3.31, 1 lv. Timber Cove, Sonoma County, California $38^{\circ} 31.9^{\prime} \mathrm{N}, 123^{\circ}$ 17.3' W, 31 March 1962, intertidal, LACM 1962-1.26, 2 lv. $1.6 \mathrm{~km}$ south of Puerto Santo Tomas, Baja California, $31^{\circ} 32^{\prime} \mathrm{N}, 116^{\circ} 40^{\prime} \mathrm{W}, 4$ January 1966, intertidal, LACM 1966-1.43, 1 dd.

Distribution. Known from Kenai Peninsula, Kenai-Cook County, Alaska $\left(59^{\circ} \mathrm{N}\right)$, to Santo Tomas, Baja California $\left(31^{\circ} \mathrm{N}\right)$. Occasionally common in rocky areas $(0-34 \mathrm{~m})$ throughout the range, but submergent, and remarkably rare south of Point Conception, Santa Barbara County, California, reappearing in the upwelling area near Santo Tomas, Baja California.

Description. Shell reaching up to $25.0 \mathrm{~mm}$ in length, rib sculpture variable, generally thick shelled, wide incised lines between cords, general shape elongate ovate, robust, color light yellow, red-orange, brown, or purplish black, occasionally with lighter, or darker, thick band at periphery, dark bands sometimes broken, incised lines, siphonal canal usually lighter. Spire moderately tall, subsutural ramp variable, protoconch bulbous, teleoconch sculpture with thick cords, ribbing more evident in early whorls, later whorls having faint to strong ribs, sometimes absent, siphonal canal wide, extremely thick. Spiral cords broad, thick, faintly scabrous, projecting in third, fourth teleoconch whorls, interspaces narrow. First, second whorl with IP, P1, P2, third with IP, P1, P2, starting s2, P3, P4, fourth with IP, P1, P2, s2, P3, P4, starting P5, P6; last whorl with 
SP, adis, IP, P1, s1, P2, s2, P3, s3, P4, s4, P5, s5, P6, s6, ADP, MP, ABP. Primary, secondary cords on final teleoconch whorl similar in size, strength. Aperture ovate, outer lip very thick, parietal wall strong. Denticle morphology with D1-D6.

Remarks. Paciocinebrina lurida (Middendorff, 1848) possesses the largest known geographic range of all species in this genus and is more abundant in the cool northern waters from lower intertidal to subtidal depths, remaining scarce in localities south of Point Conception, Santa Barbara County, California. The range in shell size, shape, and strength of ribs in this species seems less evident than in that of $P$. foveolata, although the coloration is more variable, ranging from bright orange to black, with dark dashed banding in some specimens from central California. The spiral and denticle morphology of P. lurida (Fig. 7B, E) and P. aspera (Figs 7A-D) are identical, and $P$. aspera is here found to be a junior synonym of $P$. lurida. The confusion and use of these names interchangeably, has brought to attention the need to rectify the taxonomy of this species. Paciocinebrina sclera has far more spiral cords, with $\mathrm{t}$ cords before adis, after s1, after P2, after s2, presence of abis, ms, absence of SP and s6, a taller spire, elongate siphonal canal, more denticles and is much larger in size compared to P. lurida. The holotype of P. munda (Carpenter, 1864) is smaller in size, extremely slender in profile and has fewer spiral cords with SP, s4 and s6 absent, and a D6 split in denticles compared to $P$. lurida.

\section{Paciocinebrina macleani new species}

(Figures 7H, 8B, 22A-B)

Type material. Off Caleta Melpomene, Guadalupe Island, Baja California ( $\left.28^{\circ} 52.13^{\prime} \mathrm{N}, 118^{\circ} 15.98^{\prime} \mathrm{W}\right), \mathrm{R} / \mathrm{V}$ Velero IV 1920-49, 19 December 1949, on sand, 92 m, holotype LACM 3049 (ex LACM 1949-158.6), length $11.2 \mathrm{~mm}$, width $6.4 \mathrm{~mm}, 1 \mathrm{dd}$.

Distribution. Only known from the type locality.

Description. Shell extremely small, robust, thick in structure, shape somewhat rotund, subsutural ramp tabulate, sutures indented, projecting at periphery, especially in later whorls, operculum unknown, length 11.1 $\mathrm{mm}$, width $6.7 \mathrm{~mm}$ (holotype). Color creamy white with one orangish brown band on center of final body whorl, aperture light peach. Spire short, compressed, protoconch whorls missing in holotype, early teleoconch whorls slightly cancellate, finely scabrous between ribs, with minute cords, periphery progressively projecting anteriorly, becoming spine-like on final whorls, ribs strong, blade-like, siphonal canal relatively long, thick, wide, spiral cords robust, strong, weakly cancellate. Cord sculpture rotund, overridden by frequent, blade-like ribs, cords near periphery projecting outward. First whorl with SP, P1; second, third with SP, P1, starting P2; final whorl with SP, P1, P2, starting abis, s1 split, P3, P4, P5, s5, ADP, MP, ABP. Size of primary, secondary cords variable in strength on final whorl. Denticles faint with D1-D5. Aperture large, squarishly ovate, flaring at perimeter, lip heavily thickened, parietal wall weak with four faint denticles.

Remarks. Paciocinebrina macleani is unique in its extremely small size and is comparable only to the much larger, P. foveolata (Figs 7C, F, 21G-L, 22C-D). Paciocinebrina macleani has subtle but projecting peripheral spines and blade-like ribs, not seen in $P$. foveolata. The smallest mature specimen identified as $P$. foveloata, from Baja California, measures $13.6 \mathrm{~mm}$, largest juvenile $11.8 \mathrm{~mm}$. These and other juvenile specimens consistently match, other than final P6 and s6 cords, mature specimens of $P$. foveolata in having adis, IP, t following IP, t after P1, s3, s4, P6, s6 and abs not seen in P. macleani, which also has SP, s1 split and one less denticle. Paciocinebrina macleani differs from P. seftoni Chace, 1958 (Fig. 22E-F) by the blade-like ribs, a shorter siphonal canal, different spiral cord sequence with no adis, IP, s2, s3 and P6 cords, P. seftoni lacking P6 and ADP.

Etymology. Named in the honor of the late James Hamilton McLean, whose immense wisdom and infinite knowledge of malacology served as a great inspiration to the people who knew him.

\section{Paciocinebrina neobarbarensis new species}

(Figures 8F-I, 23G-H)

Tritonalia barbarensis (non Gabb, 1865). Dall 1921: 108, pl. 6, fig. 5, pl. 15, fig. 11. Oldroyd 1924: 101, pl. 20, fig. 9. Oldroyd 1927: 25-26, pl. 30, fig. 5.

Ocenebra barbarensis (non Gabb, 1865). Abbott 1974: 183, fig. 1915. Fair 1976: 24, pl. 21, fig. 330. McLean 1978: 42, fig. 22.2 .

Ocenebra foveolata (non Hinds, 1844). Radwin \& D'Atillio 1976: 120-121, pl. 20, fig. 9.

Ocinebrina barbarensis (non Gabb, 1865). McLean 1996: 81-82, fig. 1.15B. 
Type material. $3.2 \mathrm{~km}$ southeast of Long Point, Santa Catalina Island, Los Angeles County, California, $33^{\circ}$ $22.0^{\prime} \mathrm{N}, 118^{\circ} 30.3^{\prime} \mathrm{W}, \mathrm{R} / \mathrm{V}$ Velero III 1399-41, 8 September 1941, 86 m, holotype LACM 3497 (ex LACM 1941-179.8), length $19.9 \mathrm{~mm}$, width $11.7 \mathrm{~mm}$.

Other material. Humpback Rock, off Hopkins Marine Station, Pacific Grove, Monterey Bay, Monterey County, California, 36 $38^{\prime}$ N, $121^{\circ} 54^{\prime}$ W, R/V Tage, 26 November 1963, 60 m, LACM 1963-50.14, 2 dd. off

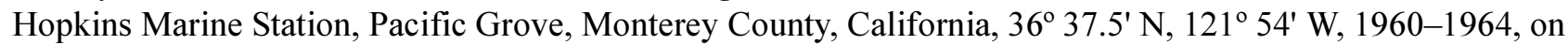
sand, $37 \mathrm{~m}$, LACM 1960-23.27, 1 dd. $10.0 \mathrm{~km} 117^{\circ} \mathrm{T}$ from Point Conception Light, Santa Barbara County, California, 34 $4^{\circ} 24.2^{\prime} \mathrm{N}, 120^{\circ} 21.5^{\prime} \mathrm{W}, \mathrm{R} / \mathrm{V}$ Velero IV 5560-58, 28 January 1958, in fine green sand, $91 \mathrm{~m}$, LACM 1958-15.19, 1 dd. $3.2 \mathrm{~km} 229^{\circ}$ T from Santa Barbara Point Light, Santa Barbara County, California, $34^{\circ} 22.4^{\prime} \mathrm{N}, 119^{\circ} 45.3^{\prime} \mathrm{W}, \mathrm{R} / \mathrm{V}$ Velero IV 5171-57, 3 July 1957, in silt, $62 \mathrm{~m}$, LACM 1957-119.9, $1 \mathrm{dd}$. Off Refugio Beach, Santa Barbara County, California, 34 $25^{\prime} \mathrm{N}, 120^{\circ} 05^{\prime} \mathrm{W}, \mathrm{R} / \mathrm{V}$ Kildee, April 1974, $238 \mathrm{~m}$, LACM 1974-69.20, 1 dd. Naples Point, Isla Vista, Santa Barbara County, California, trawled, 238 m, Paul Tuskes coll., 1 dd. $7.0 \mathrm{~km} 150^{\circ} \mathrm{T}$ from Santa Barbara Breakwater Light, Santa Barbara County, California, $34^{\circ} 20.47^{\prime} \mathrm{N}, 119^{\circ} 38.3^{\prime} \mathrm{W}, \mathrm{R} / \mathrm{V}$ Velero IV 4827-57, 17 January 1957, $51 \mathrm{~m}$, LACM 1957-33.14, 1 dd. 4.9 km south of Port Hueneme, Ventura County, California, $34^{\circ} 05.5^{\prime} \mathrm{N}, 119^{\circ} 12.7^{\prime} \mathrm{W}, \mathrm{R} / \mathrm{V}$ Velero III 1274-41, 23 March 1941, in shell and mud bottom, 53-55 m, LACM 1941-54.13, 3 dd. 9.6 km east of South Point, Santa Rosa Island, Santa Barbara County, California, 33 53.5' N, $119^{\circ} 59.8^{\prime} \mathrm{W}, \mathrm{R} / \mathrm{V}$ Velero III 1292-41, 11 April

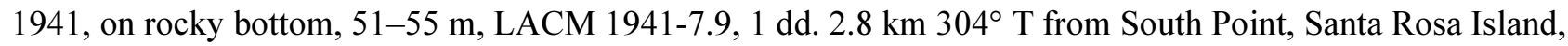
Santa Barbara County, California, $33^{\circ} 52.97^{\prime}$ N, 120 04.89' W, R/V Velero IV 23043-75, 17 October 1975, 61 m, LACM 1975-360, 1 dd. 4.5 km 122 ${ }^{\circ}$ T from San Pedro Point, Santa Cruz Island, Santa Barbara County, California, $34^{\circ} 00.39^{\prime} \mathrm{N}, 119^{\circ} 28.22^{\prime} \mathrm{W}$, R/V Velero IV 3022-55, 2 April 1955, on rocky bottom, $59 \mathrm{~m}$, LACM 1955-15.7, 1 dd. 5.6 km northeast of San Pedro Point, Santa Cruz Island, Santa Barbara County, California, $34^{\circ}$ 03.5' N, $119^{\circ} 28.3^{\prime} \mathrm{W}, \mathrm{R} / \mathrm{V}$ Velero III 1418-41, 17 September 1941, in sand, 84-86 m, LACM 1941198.21, 1 dd. 2.4 km northwest of Cavern Point, Santa Cruz Island, Santa Barbara County, California, $34^{\circ}$ 04.6' N, 119 34.4' W, R/V Velero III 1300-41, 12 April 1941, in mud, sand and shell bottom, 99-102 m,

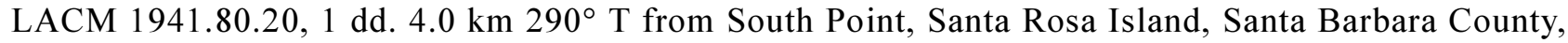
California, 33 53.11' N, $120^{\circ}$ 03.96' W, R/V Velero IV 23042-75 (= LACM 1975-359), 17 October 1975, 52 m, 2 dd. $4.3 \mathrm{~km} 130^{\circ} \mathrm{T}$ from San Pedro Point, Santa Cruz Island, Santa Barbara County, California, $34^{\circ} 00.3^{\prime}$ $\mathrm{N}, 119^{\circ} 28.7^{\prime} \mathrm{W}$, R/V Velero IV 12300-68, 9 August 1968, 51 m, LACM 1968-149.6, 1 dd. 4.0 km northwest of Anacapa Island Light, Ventura County, California, $34^{\circ} 03.0^{\prime} \mathrm{N}, 119^{\circ} 23.8^{\prime} \mathrm{W}$, R/V Velero III 1268-41, 16 March 1941, in gray green sand, 88-93 m, LACM 1941-48.13, 1 dd. 4.8 km northwest of Anacapa Island

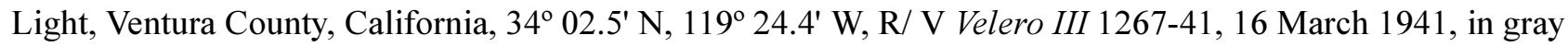
green sand, 86-95 m, LACM 1941-47.14, 2 dd. Point Dume, Los Angeles County, California, 1958, LACM 11389, 1 dd. Redondo Submarine Canyon, off Redondo Beach, Los Angeles County, California, $33^{\circ} 50^{\prime} \mathrm{N}$, $118^{\circ} 25^{\prime} \mathrm{W}, 1938,91 \mathrm{~m}, \mathrm{LACM} 38-15.24,1$ dd. Off Palos Verdes, Los Angeles County, California, 32 ${ }^{\circ}$ 42.0' N, $118^{\circ}$ 21.2' W, R/V Vantuna, 15 March 1978, dredged on rubble bottom, 85 m, SW 11, 1 dd. Point Fermin, near San Pedro, Los Angeles County, California, 29 March 1924, LACM 151009, 1 dd. 1.6 km east of Empire Landing, Santa Catalina Island, Los Angeles County, California, $33^{\circ} 25.0^{\prime} \mathrm{N}, 118^{\circ} 22.8^{\prime} \mathrm{W}, \mathrm{R} / \mathrm{V}$ Velero III 1374-41, 3 August 1941, on coarse sand and shell hash, 40 m, LACM 41-154.5, 1 dd. 0.4 km off Willow Cove, Santa Catalina Island, Los Angeles County, California, 33 $22.65^{\prime} \mathrm{N}, 118^{\circ} 20.74^{\prime} \mathrm{W}$, R/V Velero IV 1990-50, 13 August 1950, on mud , 68 m, LACM 50-46.5, 1 dd. Santa Catalina Island, Los Angeles County, California, 73 m, LACM 60853, 1 dd. Santa Catalina Island, Los Angeles County, California, 55 m, LACM 151011,3 dd. $16.2 \mathrm{~km} 150^{\circ} \mathrm{T}$ from Point Loma Light, San Diego County, California, $32^{\circ} 31.20^{\prime} \mathrm{N}, 117^{\circ} 08.5^{\prime}$ W, R/V Velero IV 5608-58 (= LACM 58-34), 18 February 1958, on rocks, 15 m, 1 dd. Kellett Channel, south of Cedros Island, Baja California, $27^{\circ} 57.0^{\prime} \mathrm{N}, 115^{\circ} 08.5^{\prime} \mathrm{W}, \mathrm{R} / \mathrm{V}$ Searcher, 20 October 1971, in shelly sand, 31-37 m, LACM 71-158.40, 9 dd. 13.6 km south of Cedros Island, Baja California, $27^{\circ} 55.2^{\prime} \mathrm{N}, 115^{\circ} 21.31^{\prime}$ W, R/V Velero III 1256-41, 27 February 1941, on fine gray green mud and small shells, 95-101 m, LACM 41$36.6,1$ dd. $2.4 \mathrm{~km}$ off north end of Cedros Island, Baja California, $28^{\circ} 23.3^{\prime} \mathrm{N}, 115^{\circ} 11.87^{\prime} \mathrm{W}$, R/V Velero III 1264-41, 28 February 1941, on shale and pebbles, 101-110 m, LACM 41-44.11, 1 dd. off Point Rompiente, Baja California Sur, $27^{\circ} 41.7^{\prime} \mathrm{N}, 115^{\circ} 05.3^{\prime} \mathrm{W}$, R/V Searcher, 22 October 1971, on shale and gravel, $89.6 \mathrm{~m}$, LACM 71-168.15, 3 dd.

Distribution. Known from Humpback Rock, Monterey Bay, Monterey County, California $\left(36^{\circ} \mathrm{N}\right)$, to Punta Rompiente, Baja California Sur $\left(27^{\circ} \mathrm{N}\right), 15-238 \mathrm{~m}$.

Description. Shell small, length $19.9 \mathrm{~mm}$, width $11.7 \mathrm{~mm}$ (holotype), spire extremely acute, projecting 
spines at periphery evident, sometimes faint until final whorl. Spiral cords highly scabrous, especially in final whorls, shape elongate rhomboid, narrow in profile, suture indented more so in later whorls, color tan, aperture white. Protoconch tabulate, initial keel strong, evolving into two cords on teleoconch whorls, eventually projecting, especially at periphery. First whorl with P1, P2, second, third whorls with P1, P2, starting s1, fourth whorl with P1, s1, P2, starting P3, fifth whorl with P1, s1, P2, P3, starting IP, s2, s3; final whorl with IP, P1, t, s1, t, P2, s2, P3, s3, P4, P5, s5, P6, s6, ADP, MP, ms, ABP. Primary, secondary, tertiary cords variable in size, strength. Denticle morphology with D1-D6. Aperture elongate ovate, lip thick with highly scabrous sculpture, cords projecting, parietal wall thickest centrally, thinning above and below, more so anteriorly, denticles on outer lip somewhat faint, siphonal canal thick, very elongate.

Remarks. The concept of $P$. barbarensis has been limited to the original description by Gabb (1865) while an illustration by Dall (1921: pl. 6, fig. 5; pl. 15, fig. 11) is here regarded as P. neobarbarensis. The original description of $P$. barbarensis by Gabb (1865) needs careful analysis to distinguish it from the similar appearing species, P. neobarbarensis. Several additional authors (Fair 1976, McLean 1978, 1996) have illustrated specimens matching the holotype of $P$. neobarbarensis under the name P. barbarensis. McLean (1996) designated the lectotype for P. barbarensis, but figured (McLean 1996: 81, fig. 1.15B) a specimen of the here described $P$. neobarbarensis. The lectotype is here figured (UCMP 10611, Fig. 24A-B). Three paralectotype specimens are confirmed to be $P$. barbarensis (UCMP 10613-10615) while one is identified as a juvenile $P$. cf. foveolata (UCMP 10612). The differing morphology in these two taxa has resulted in the description of this new deep-water species.

Paciocinebrina barbarensis (Figs 9G-I, 10A-C, 24A-J) has adis and abis, not seen in P. neobarbarensis, a species which also possesses s6 and ms cords. Paciocinebrina crispatissima (Berry, 1958) (Figs 8E, H, 23IJ) differs in the overall broad, inflated whorls, convex shoulder, strong ribs, obtuse spire, spiral morphology with additional. For comparison with $P$. benitoensis (Figs 8D, G, 23C-F) see that species. With the exception of $P$. barbarensis (Gabb, 1865), all species are deep-water taxa.

Etymology. The name neobarbarensis represents the new name assigned to this deep water taxon, long regarded as $P$. barbarensis.

\section{Paciocinebrina pseudomunda new species}

(Figures 10E, H, 22I-J)

Type material. Slate Rock, Big Sur, Monterey County, California, 36 07.599' N, 121 $38.992^{\prime}$ W, 23 Jun 2017, on rocky reef at $19.5 \mathrm{~m}$ (= SW 12), holotype LACM 3498, length 11.8, width $5.4 \mathrm{~mm}, 1 \mathrm{lv}$.

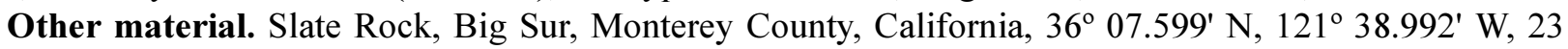
June 2017, on rocky reef, $19.5 \mathrm{~m}$ (=SW 13), 1 lv. Pheiffer Five dive site, Big Sur, Monterey County, California, 36 ${ }^{\circ} 13^{\prime} 1.02^{\prime \prime} \mathrm{N}, 121^{\circ} 46^{\prime} 8.70^{\prime \prime} \mathrm{W}, 21$ June 2014, in rubble, 27-30 m (= SW 14), 1 dd. Slate Rock,

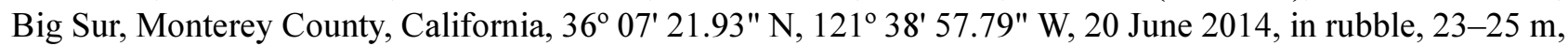

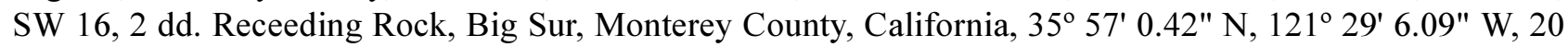
June 2014, in rubble, 16-21 m (=SW 17), 1 dd. Northern Point Sierra Nevada, San Luis Obispo County,

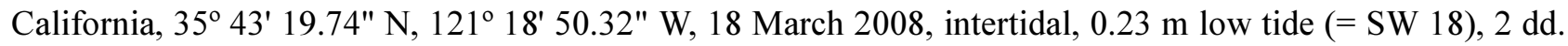

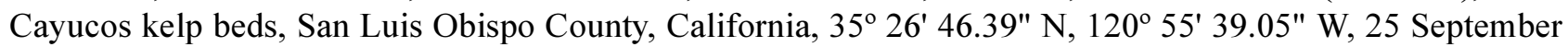
2011, on rocks, 3-5 m (= SW 19), 1 dd.

Distribution. From Slate Rock, Big Sur, Monterey County, California $\left(36^{\circ} \mathrm{N}\right)$, to Cayucos, San Luis Obispo County, California $\left(35^{\circ} \mathrm{N}\right)$.

Description. Shell extremely small for genus, length $11.8 \mathrm{~mm}$, width $5.4 \mathrm{~mm}$ (holotype), spire tall, protoconch often truncated, dark colored horizontal dashes characteristic. Spiral cords with strong microscopic ribs, shape slender, elongate, color orange, with dark brown horizontal dashes on primary ribs, rarely all brown. Spire acute, slender, protoconch bulbous, teleoconch sculpture with peripheral keel, one keel below, heavy ribbing in subsequent whorls. First whorl missing in holotype, second whorl with P1, P2, third with P1, P2, starting IP, fourth whorl with SP, IP, P1, P2, starting s2, P3, s3, fifth whorl with SP, IP, P1, P2, s2, P3, s3 starting adis; last whorl with SP, adis, IP, P1, s1, P2, s2, P3, s3, P4, s4, P5, P6, s6, MP, ABP. Primary cords somewhat bulbous at rib intersections, secondary cords vary in strength. Denticle morphology D1-D6 split; D1 weak. Aperture elongate ovate, lip slightly projected at anterior end, parietal wall long, relatively wide, denticles in outer lip somewhat weak, canal not fully sealed in holotype. 


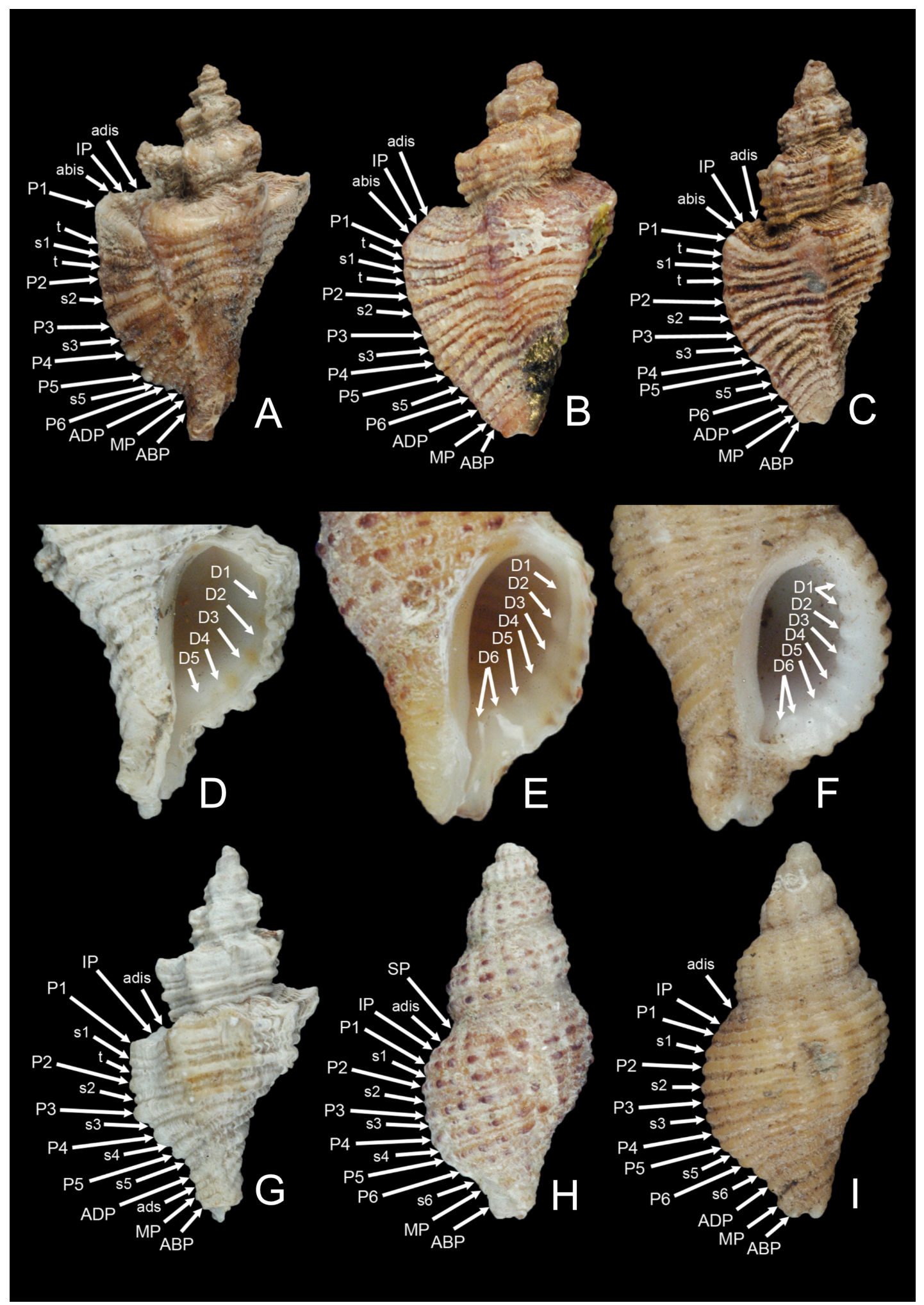

FIGURE 10. Spiral cords and apertural denticles morphology of northeastern Pacific Muricidae. A-C. Paciocinebrina barbarensis (Gabb, 1865). A. Santa Catalina Island, Los Angeles County, California, $73.1 \mathrm{~m}$, lectotype of Murex (Muricidea) barbarensis Gabb, 1865, UCMP 10611, 19.2 mm. B. White's Point, San Pedro, Los Angeles County, California, holotype of Ocenebra keenae Bormann, 1946, CASIZ 064477, 18.8 mm. C. Monterey Bay, Monterey County, California, holotype of Paciocinebrina beta (Dall, 1919), USNM 46728, 21.1 mm. D-G. Paciocinebrina fraseri (Oldroyd, 1920). Brandon Island, Departure Bay, Vancouver Island, British Columbia, Canada, holotype CASIZ 064275, 18.8 mm. E-H. Paciocinebrina

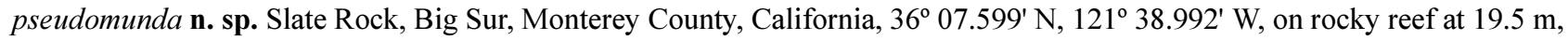
holotype LACM 3498, 11.8 mm. F-I. Paciocinebrina munda (Carpenter, 1864). Monterey Bay, Monterey County, California, holotype of Paciocinebrina munda (Carpenter, 1864), USNM 46708, $16.2 \mathrm{~mm}$. 



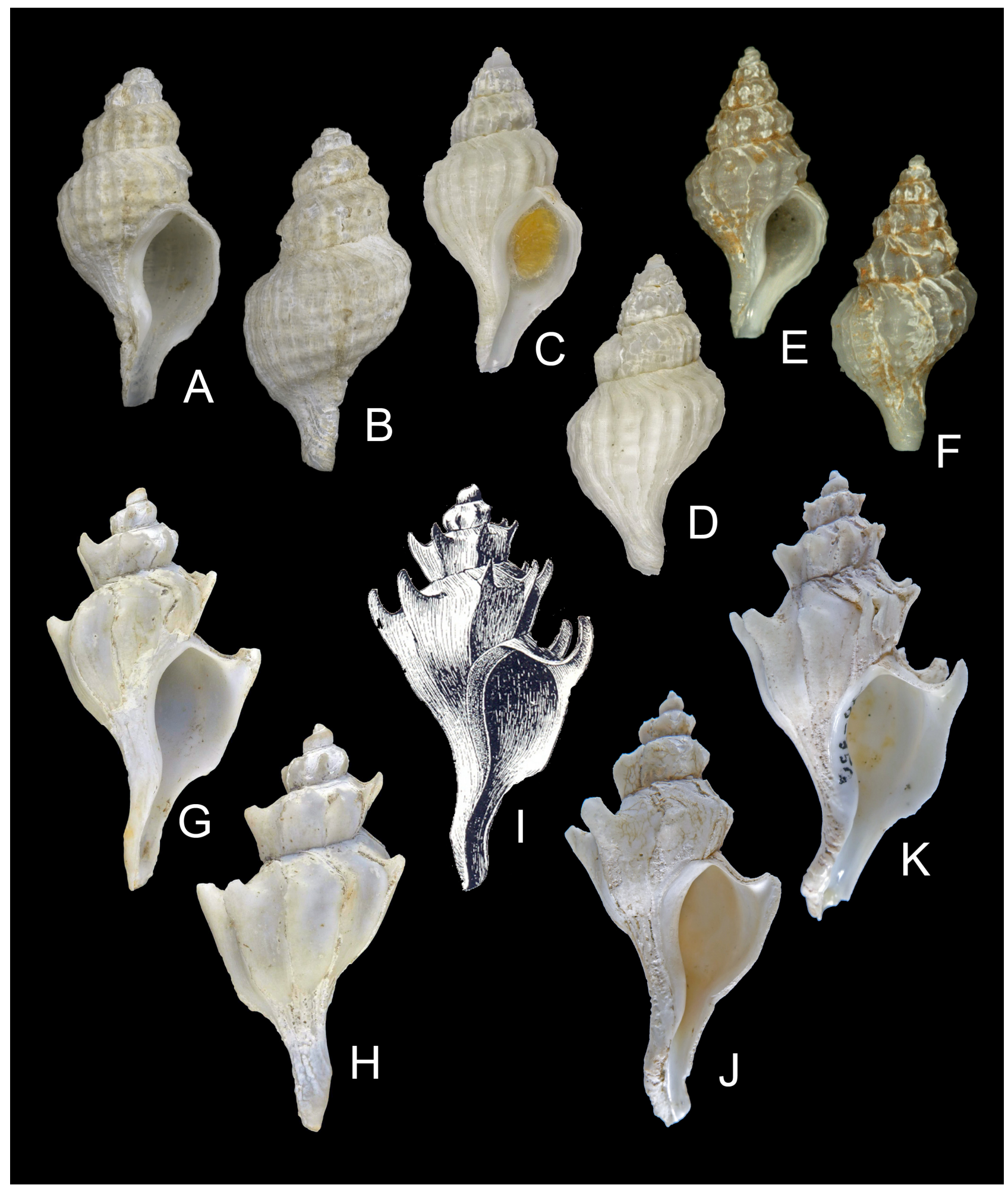

FIGURE 12. A-F. Boreotrophon kamchatkanus Dall, 1902. A-B. Southeast coast of Kamchatka, 16 fms, holotype USNM 109178, 25 mm (photo courtesy USNM). C-D. S of Attu, Aleutian Islands, Alaska, 166 m, LACM 1997-163.9, 19.2 mm. E-F. $39^{\circ} 59.8^{\prime} \mathrm{N}-39^{\circ} 59.5^{\prime} \mathrm{N}, 142^{\circ} 14.5^{\prime} \mathrm{E}-142^{\circ} 12.9^{\prime} \mathrm{E}, 194 \mathrm{~m}$, holotype of Trophonopsis nanus Egorov, 1994, ZMMSU Lc-21262, $9.8 \mathrm{~mm}$ (photo courtesy ZMMSU). G-J. Boreotrophon alaskanus Dall, 1902. G-H. N of Unalaska, Fox Islands, Aleutian Islands, $411 \mathrm{~m}$, holotype USNM 122594, $32 \mathrm{~mm}$ (photo courtesy USNM); I. Reproduced from Dall, 1925: pl. 22, fig. 3; J. Bering Sea, 60³9' N, 178 $59^{\prime}$ W, 290 m, RH, 42.8 mm; K. NW of Pribilof Islands, Bering Sea, Alaska, 117 m, LACM $1990-$ $350.1,48 \mathrm{~mm}$ 


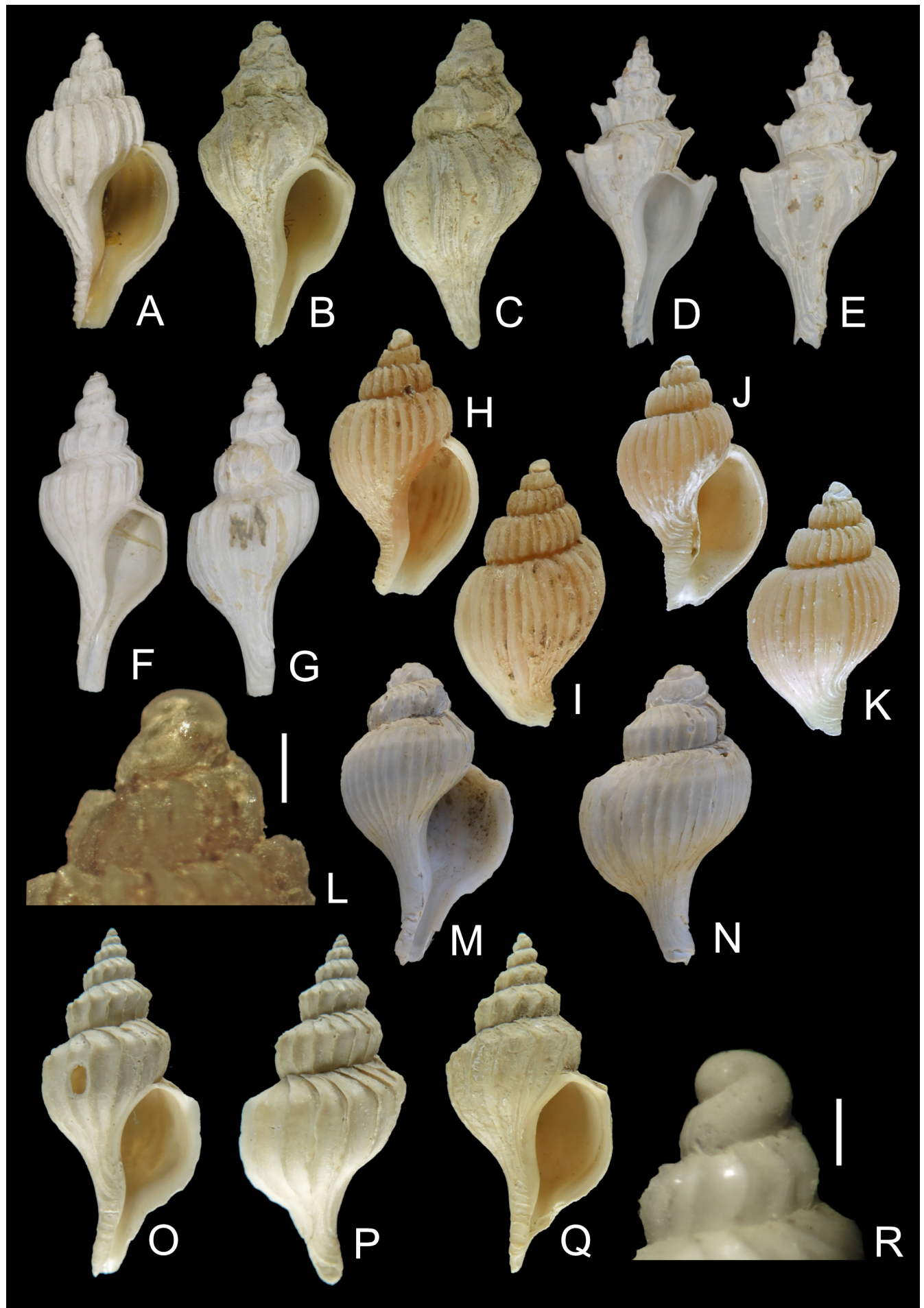

FIGURE 13. A. Boreotrophon pacificus Dall, 1902. E. Barkley Sound, Vancouver Island, British Columbia, 90 m, LACM 1967-142.1, 16.4 mm. B-C. Boreotrophon cortesianus n. sp., of Cortes Bank, W of San Diego, 40 m, California, holotype CASIZ 102992, 18.2 mm. D-E. Boreotrophon avalonensis Dall, 1902. Off Avalon, Santa Catalina Island, California, holotype USNM 109109, 16.5 mm (photo courtesy USNM). F-G. Boreotrophon eucymatus Dall, 1902. A-B. San Diego, California, 124 fms, lectotype USNM 109087, 20.7 mm (photo courtesy USNM). H-L. Boreotrophon obesus $\mathbf{n}$. sp. H-I. NE of Adak Island, Andreanof Island, Aleutian Islands, Alaska, $51^{\circ} 58.50^{\prime} \mathrm{N}, 176^{\circ} 22.95^{\prime} \mathrm{W}, 121 \mathrm{~m}$, holotype LACM 3395, 8.4 mm. J-K. Inanudak Bay, NW side Umnak Island, Aleutian Islands, Alaska, $53^{\circ} 22.38^{\prime} \mathrm{N}, 168^{\circ} 34.42^{\prime} \mathrm{W}, 90$ m, paratype LACM 3396, 6.6 mm. L. Protoconch, holotype, scale bar $500 \mu \mathrm{m}$. M-N. Boreotrophon tolomius (Dall, 1919). Off San Miguel Island, California, holotype USNM 222441, $19.31 \mathrm{~mm}$ (photo courtesy USNM). O-R. Boreotrophon subapolyonis n. sp. O-P. Off Tanner Bank, California, $32^{\circ} 47.5^{\prime} \mathrm{N}, 119^{\circ} 15.5^{\prime} \mathrm{W}, 1977$, 511-530 m, holotype LACM 3398, $20.9 \mathrm{~mm}$. Q. Off Tanner Bank, SW of San Clemente Island, California, $32^{\circ} 40.97^{\prime} \mathrm{N}, 119^{\circ} 14.04^{\prime} \mathrm{W}, 390 \mathrm{~m}$, paratype LACM 3400, $14 \mathrm{~mm}$; R. Protoconch. Off Tanner Bank, California, $32^{\circ} 47.5^{\prime} \mathrm{N}, 119^{\circ} 15.5^{\prime} \mathrm{W}, 511-530 \mathrm{~m}$, paratype LACM 3399 (juv.), scale bar $500 \mu \mathrm{m}$. 


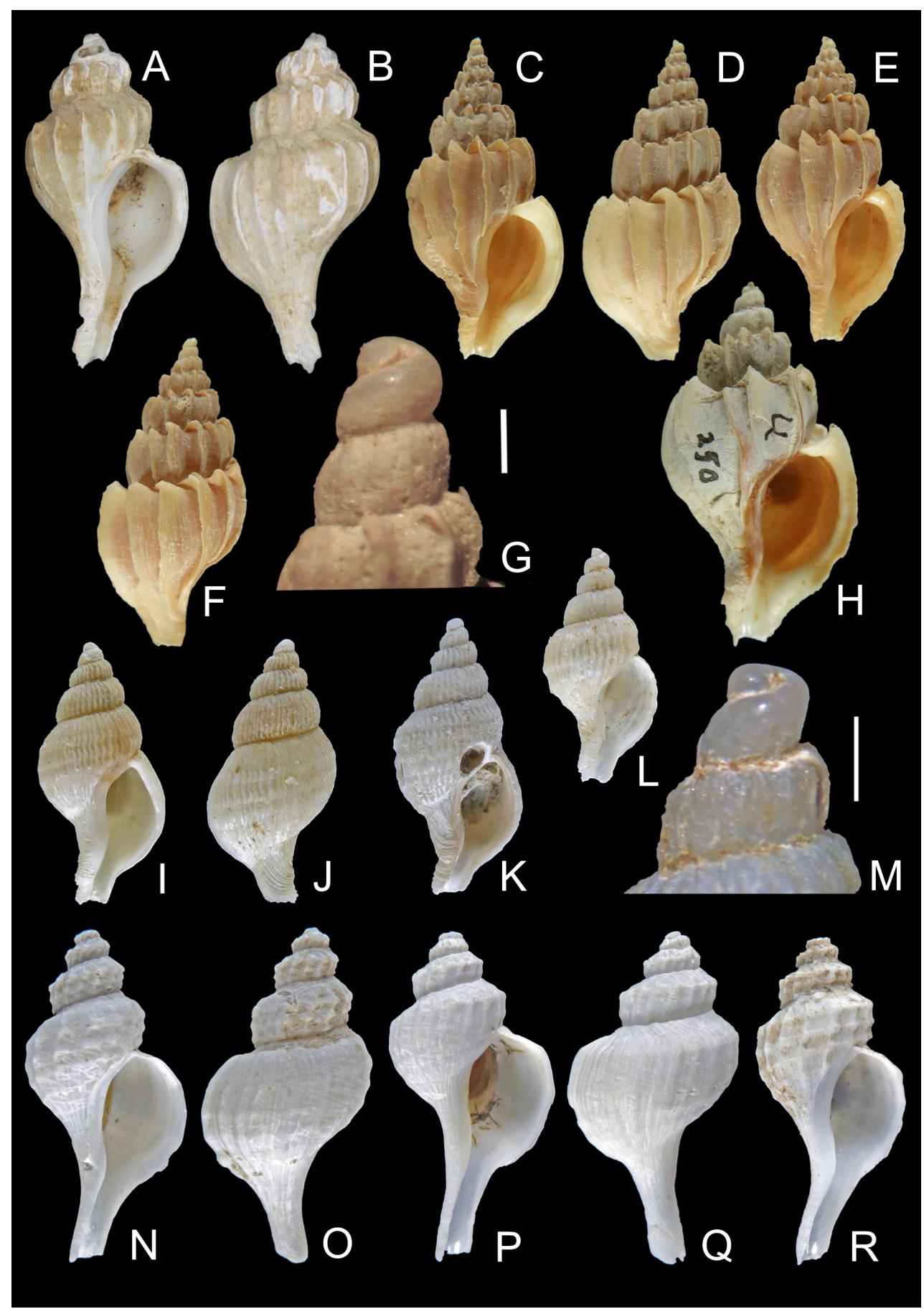

FIGURE 14. A-B. Boreotrophon apolyonis (Dall, 1919), off San Nicholas Island, California, lectotype USNM 209303, 20.6 $\mathrm{mm}$ (photo courtesy USNM). C-G. Boreotrophon vancouverensis n. sp. C-D. Entrance to Bull Harbor, Hope Island, N end Vancouver Island, Rupert District, British Columbia, $50^{\circ} 54.1^{\prime} \mathrm{N}, 127^{\circ} 56.3^{\prime} \mathrm{W}$, Intertidal to $2 \mathrm{~m}$. Holotype LACM $3401,16.6$ mm. E-F. Paratype MNHN IM-2014-6477, 14.4 mm. G. Protoconch, paratype LACM 3402, scale bar $500 \mu \mathrm{m} . \mathrm{H}$. Boreotrophon multicostatus (Eschscholtz, 1829), 59 $28^{\prime} \mathrm{N}, 151^{\circ} 43^{\prime} \mathrm{W}$, Alaska, RH, $25.5 \mathrm{~mm}$. I-M. Boreotrophon aleuticus $\mathbf{n}$. sp. I-J. NE of Semisopochnoi Island, Rat Islands, Aleutian Islands, Alaska, 52 $21.44^{\prime} \mathrm{N}, 179^{\circ} 49.23^{\prime} \mathrm{W}, 168 \mathrm{~m}$, holotype LACM 3403, $8.4 \mathrm{~mm}$. K. Sitkin Strait, Adak Island, Andreanof Islands, Aleutian Islands, County, Alaska, $51^{\circ} 54.8^{\prime} \mathrm{N}, 176^{\circ}$ 50.6' W, $103 \mathrm{~m}$, paratype LACM 3406, $8.7 \mathrm{~mm}$. L. NE of Adak Island, Andreanof Islands, Aleutian Islands, Alaska, 51 ${ }^{\circ} 58.50^{\prime}$ $\mathrm{N}, 176^{\circ} 22.95^{\prime} \mathrm{W}, 121 \mathrm{~m}$, paratype LACM 3409, $6.6 \mathrm{~mm}$. M. Protoconch. NE of Adak Island, Andreanof Islands, Aleutian Islands, Alaska, $51^{\circ} 58.50^{\prime} \mathrm{N}, 176^{\circ} 22.95^{\prime} \mathrm{W}, 121 \mathrm{~m}$, paratype LACM 3409, scale bar $500 \mu \mathrm{m}$. N-R. Boreotrophon

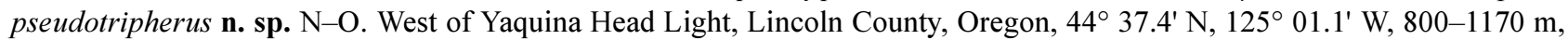

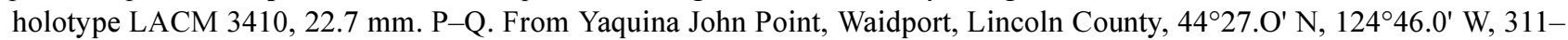

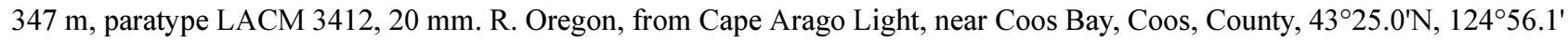
W, $800 \mathrm{~m}$, paratype LACM 3411, $19.1 \mathrm{~mm}$. 


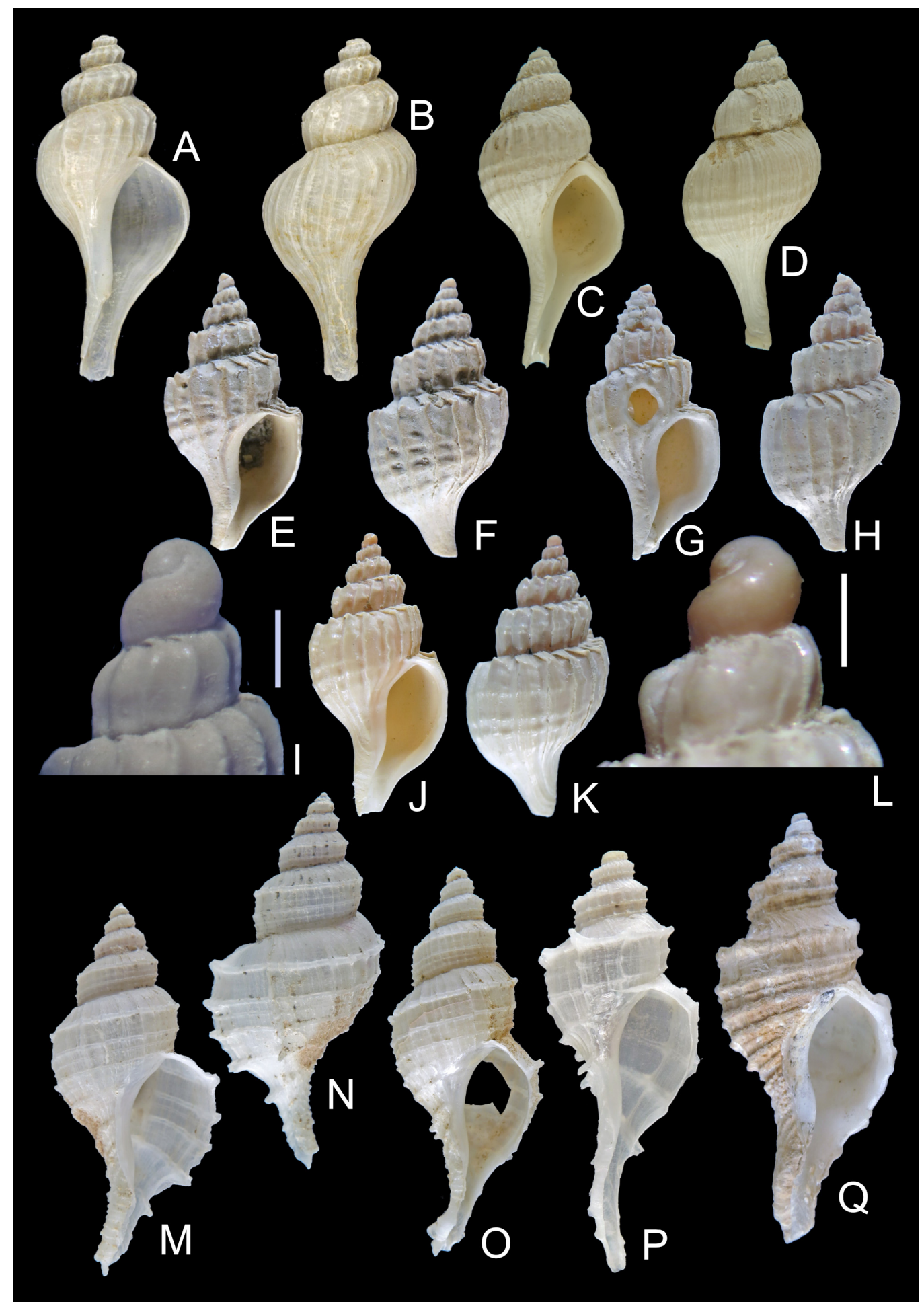

FIGURE 15. A-B. Boreotrophon tripherus Dall, 1902. Off Yaquina Head Light, Lincoln County, Oregon, 800 m, LACM 1964-105.5, $24.1 \mathrm{~mm}$. C-D. Boreotrophon disparilis (Dall, 1891). Off Eureka, California, $183 \mathrm{~m}, \mathrm{RH}, 18.2 \mathrm{~mm} . \mathrm{E}-\mathrm{I}$. Boreotrophon santarosensis n. sp. E-H. Off South Point, Santa Rosa Island, Santa Barbara County, 33 ${ }^{\circ} 50.83^{\prime}$ N, $120^{\circ} 05.95^{\prime}$ W, 115 m, California. E-F. Holotype LACM 3415, 10.4 mm. G-H. Paratype LACM 3416, 10.2 mm. I. Protoconch. Off South Point, Santa Rosa Island, Santa Barbara County, California, $33^{\circ} 50.99$ N, 120 04.91' W, 103 m, paratype LACM 3417, scale bar $500 \mu \mathrm{m}$. J-L. Boreotrophon tannerensis n. sp. J-K. Tanner Bank, SW of San Clemente Island, 32 ${ }^{\circ} 39.04^{\prime}$ N, $119^{\circ} 09.6^{\prime} \mathrm{W}$, $150 \mathrm{~m}$, California, holotype LACM 3439, 10,1 mm. L. Protoconch, holotype, scale bar $500 \mu \mathrm{m}$. M-O. Scabrotrophon buldirensis $\mathbf{n}$. sp. SW of Buldir Island, Aleutian Islands, Alaska, 52 $19.77^{\prime} \mathrm{N}, 175^{\circ} 48.56^{\prime} \mathrm{E}, 226 \mathrm{~m}$. M-N. Holotype LACM 3442, 24.7 mm. O. Paratype LACM 3443, $28.5 \mathrm{~mm}$; P. Scabrotrophon cf. buldirensis. Off Amchitka Island, Aleutian Islands, Alaska, 51 $1^{\circ} 27.70^{\prime} \mathrm{N}, 178^{\circ} 35.0^{\prime}$ E, 384 m, LACM 1997-156, 28.4 mm. Q. Scabrotrophon scitulus (Dall, 1891). Off Attu Island, Aleutian Islands, Alaska, 52 $30.54^{\prime} \mathrm{N}, 172^{\circ} 56.64^{\prime} \mathrm{E}, 159 \mathrm{~m}$, LACM 1986-309.1, $31.5 \mathrm{~mm}$. 


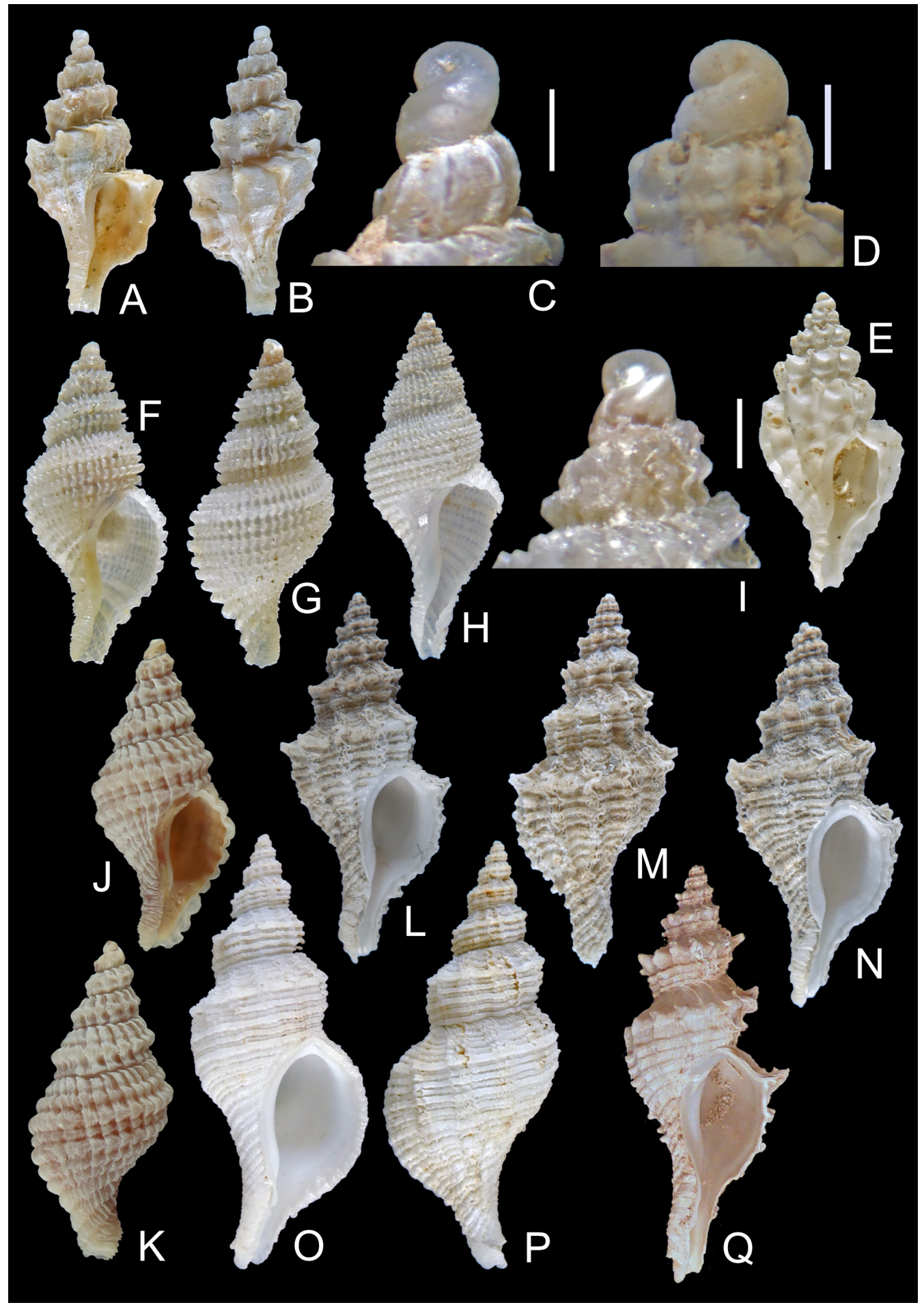

FIGURE 16. A-C. Scabrotrophon kantori n. sp. A-B. Off Santa Cruz Island, Santa Barbara County, California, 46 m, holotype LACM 3444, 8.9 mm. C. Protoconch. Holotype, scale bar $500 \mu \mathrm{m}$. D-E. Scabrotrophon stuarti (E.A. Smith, 1880), Santa Catalina Island, Los Angeles County, California, 3326.43' N, 118 26.26'W, 131 m, LACM 1954-76.8, 10 mm (juvenile). D. Protoconch, scale bar $500 \mu \mathrm{m}$. F-I. Scabrotrophon lima n. sp. F-G. NW side Kiska Island, Rat Islands, Aleutian Islands, Alaska, $52^{\circ} 03.54^{\prime} \mathrm{N}, 177^{\circ} 20.63^{\prime} \mathrm{E}, 168 \mathrm{~m}$, holotype LACM 3446, $9.8 \mathrm{~mm}$. H. SW of Buldir Island, Aleutian Islands, Alaska, $52^{\circ} 19.77^{\prime} \mathrm{N}, 175^{\circ} 48.56^{\prime} \mathrm{E}, 226 \mathrm{~m}$, paratype LACM 3447, $15.7 \mathrm{~mm}$. I. Protoconch. Holotype, scale bar $500 \mu \mathrm{m}$. J-K. Scabrotrophon tegularis (Golikov \& Gulbin, 1977). Kurile Island, $20 \mathrm{~m}$, on rocks, RH, $10 \mathrm{~mm}$. L-N. Scabrotrophon macleani n. sp. Miami Islet, Stuart Channel, N of Thetis Island, Strait of Georgia, SE Vancouver Island, 49 $02,0^{\prime} \mathrm{N}, 123^{\circ} 41,2^{\prime} \mathrm{W}$, intertidal British Columbia. K-L. Holotype LACM 3448, 23.7 mm. M-N. Paratype LACM 3449, 24,1 mm. O-P. Scabrotrophon maltzani (Kobelt \& Küster, 1878). Egmont, British Columbia, 31 m, RH, 34.6 mm. Q. Scabrotrophon grovesi McLean, 1996. Off NE side of Catalina Island, California, 79-140 m. Holotype CASIZ 074962, $28.1 \mathrm{~mm}$ (photo courtesy CASIZ). 



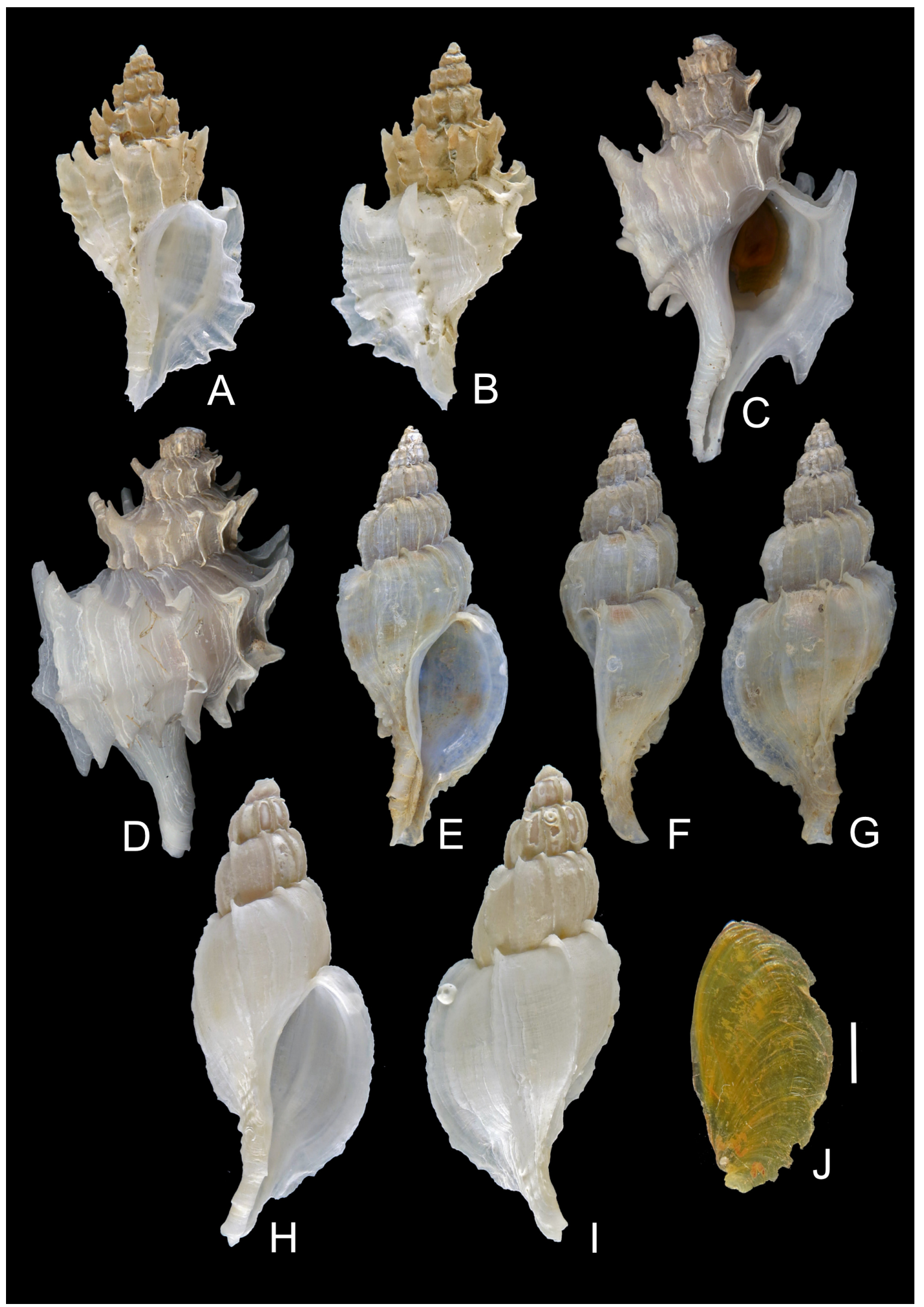

FIGURE 18. A-B. Nipponotrophon exquisitus n. sp. SW of Chirkof Island, SE of Semedi Island, Alaska, 54 58.70' N, $157^{\circ}$ 18.16' W, 167 m, holotype LACM 3455, 16.3 mm. C-D. Nipponotrophon magnificus (Golikov \& Sirenko, 1992). Eastward of Iturup Island, $44^{\circ} 20.8^{\prime} \mathrm{N}, 148^{\circ} 24.0^{\prime} \mathrm{E}, 414 \mathrm{~m}$, holotype ZIN 57625, $32.1 \mathrm{~mm}$ (photo courtesy ZIN). E-J. Warenia elegantula (Dall, 1907). E-G. Attu, Aleutian Islands, Alaska, $135 \mathrm{fms}(247 \mathrm{~m})$, holotype USNM 110501, $31.5 \mathrm{~mm}$ (photo courtesy USNM). H-J. South of Attu Island, Aleutian Islands, Alaska, 160 m, RH, 34 mm. J. Operculum, scale bar 2 mm. 


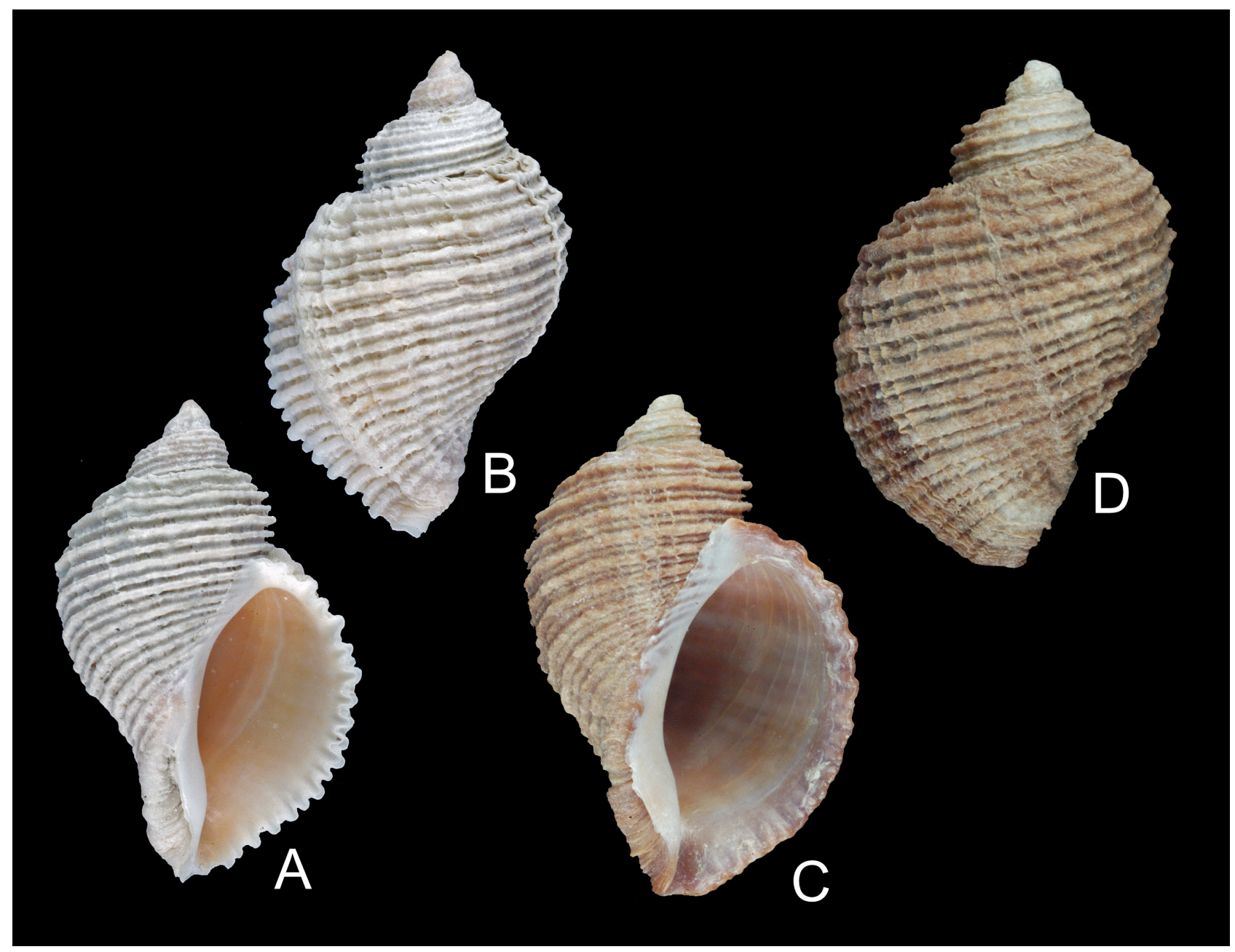

FIGURE 19. A-B. Nucella angustior n. sp. Monashka Bay, Kodiak Island, Alaska, holotype LACM 3488, 29.5 mm. C-D. Nucella lima (Gmelin, 1791). Mouth of Casco Cove, Attu Island, Aleutian Islands, Alaska, LACM 180337, 31.8 mm.

Remarks. Paciocinebrina pseudomunda seems to be endemic to central California and is primarily found at subtidal depths, intertidal specimens found worn and crabbed. This species resembles the holotype of $P$. munda (Fig. 22G-H), but is more slender in shape, has more distinct ribbing on teleoconch whorls, more dramatic, darker colored, dash marks on primary cords, and lacks s5 and ADP, but additionally has SP and s4, not seen in $P$. munda. Furthermore, the size of $P$. munda is much larger with specimens never recorded as attaining a height at maturity below $12.6 \mathrm{~mm}$, whereas specimens of $P$. pseudomunda have rarely been recorded larger than $11.0 \mathrm{~mm}$ and without sealed canals, consistently recorded with an additional teleoconch whorl despite $P$. pseudomunda being smaller in size.

Etymology. The name pseudomunda is in reference to the striking resemblance to $P$. munda.

\section{Paciocinebrina thelmacrowae new species}

(Figures 7I, 8C, 23K-L)

Type material. Off Todos Santos Island, near Ensenada, Baja California $\left(31^{\circ} 50^{\prime} \mathrm{N}, 116^{\circ} 45^{\prime} \mathrm{W}=\mathrm{LACM}\right.$ 1961-16), dredged by Thelma Crow \& Paul Watkins, 1961, 18-45 m, holotype LACM 2712, length 10.7 mm, width $5.5 \mathrm{~mm}, 1 \mathrm{dd}$.

Distribution. Only from the type locality. 


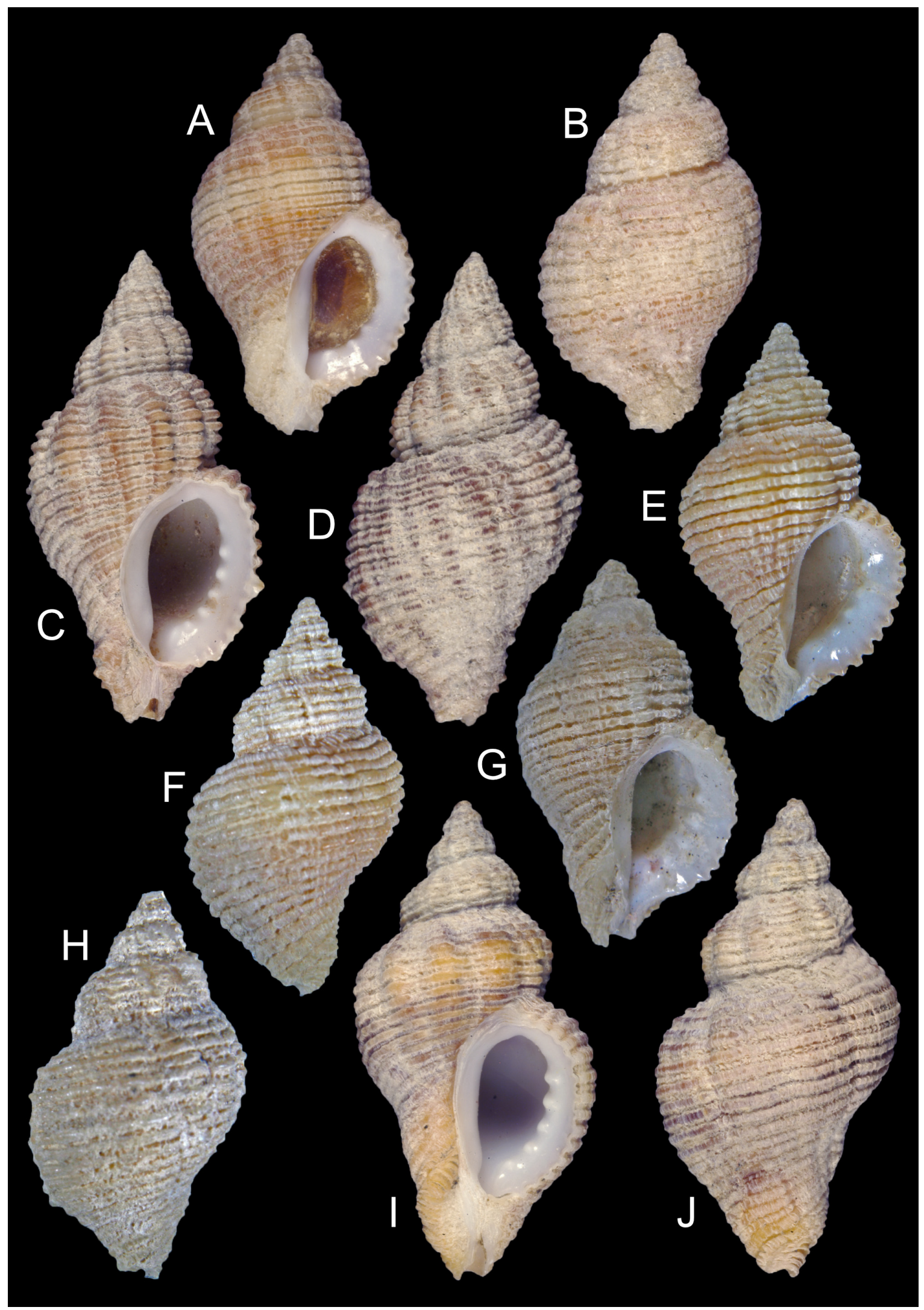

FIGURE 20. A-J. Paciocinebrina lurida (Middendorff, 1848). A-B. Timber Cove, Sonoma County, California $38^{\circ} 31.9^{\prime} \mathrm{N}$, $123^{\circ} 17.3^{\prime} \mathrm{W}$, intertidal, LACM 1962-1.26, $18.1 \mathrm{~mm}$. C-D. Mackaye Harbor, southwest end of Lopez Island, San Juan Islands, San Juan Island County, Washington $48^{\circ} 26^{\prime} \mathrm{N}, 122^{\circ}$ 53' W, intertidal, LACM 1966-39.20, 21.4 mm. E-F. Sitka, Sitka County, Alaska, Syntype of Tritonium luridum Middendorff, 1848, ZISP 62131, $18.0 \mathrm{~mm}$. G-H. $17.5 \mathrm{~mm}$. I-J. $1.6 \mathrm{~km}$ south of Puerto Santo Tomas, Baja California, 31 $32^{\circ} \mathrm{N}, 116^{\circ}$ 40' W, intertidal, LACM 1966-1.43, $21.6 \mathrm{~mm}$. 


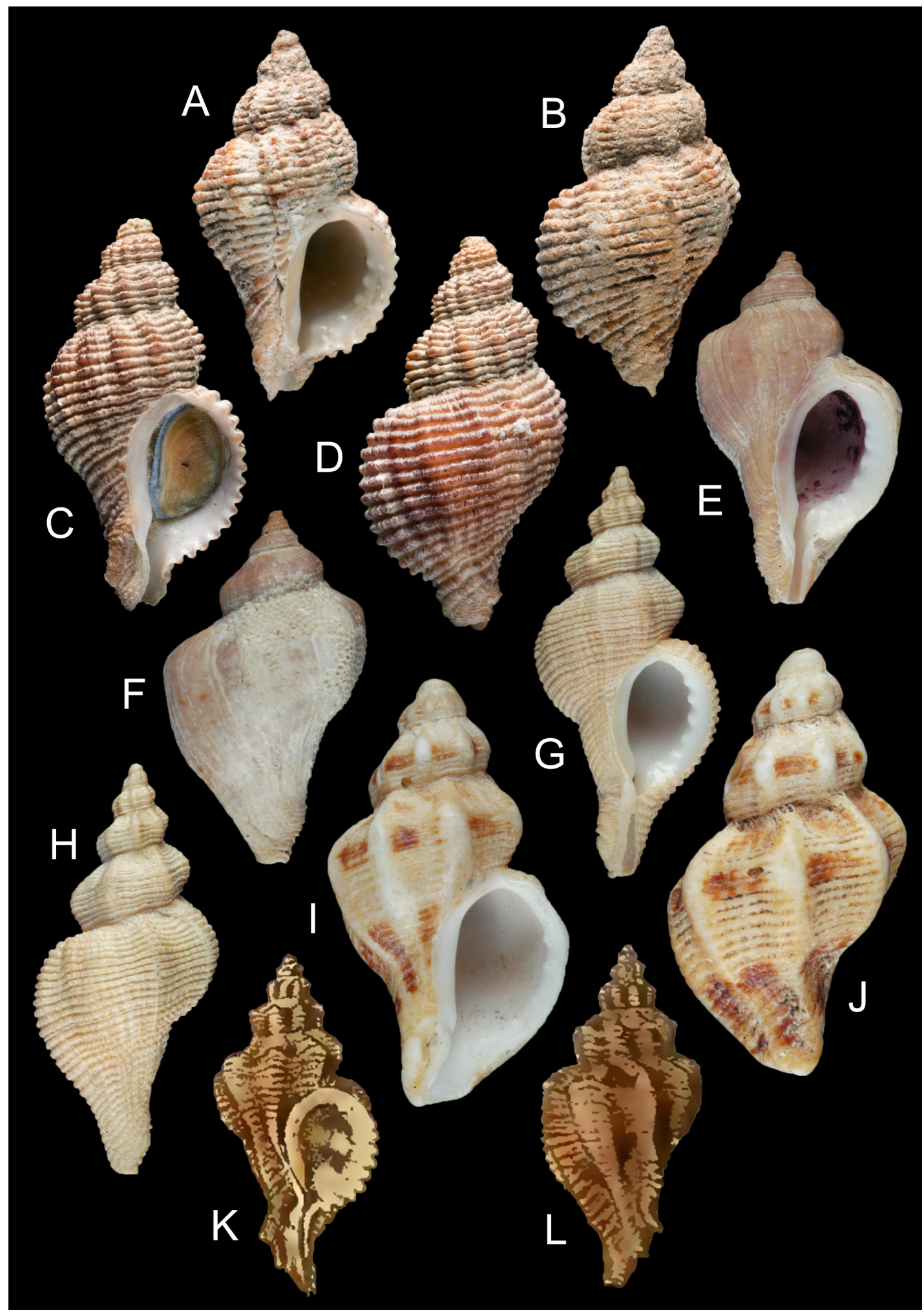

FIGURE 21. A-D. Paciocinebrina lurida (Middendorff, 1848). A-B. Syntype of Vitularia aspera Baird, 1863. Vancouver Island, British Columbia, Canada, NHMUK 1863.2.4.10/1, 21.7 mm. C-D. Syntype of Vitularia aspera Baird, 1863. Vancouver Island, British Columbia, Canada, NHMUK 1863.2.4.10/2, 23.0 mm (A-D: photos Harry Taylor, NHMUK Photographic Unit, @ Natural History Museum of London). E-F. Paciocinebrina grippi (Dall, 1919). E-F. San Diego, San Diego County, California, 27 m, holotype of Eupleura grippi Dall, 1919, USNM 228841, 20.7 mm. G-L. Paciocinebrina foveolata (Hinds, 1844). G-H. San Pedro, Los Angeles County, California, holotype of Tritonalia epiphanea Dall, 1919 , USNM 216809, $24.1 \mathrm{~mm}$. I-J. Monterey, Monterey County, California, holotype of Tritonalia fusconotata Dall, 1919, USNM 46729, $25.0 \mathrm{~mm}$. K-L. Illustrations of Murex foveolatus figured by Hinds (1844b) (not to scale). K. Dorsal view figured on pl. 3 fig. 16. L. Ventral view figured on pl. 3 fig. 15. 


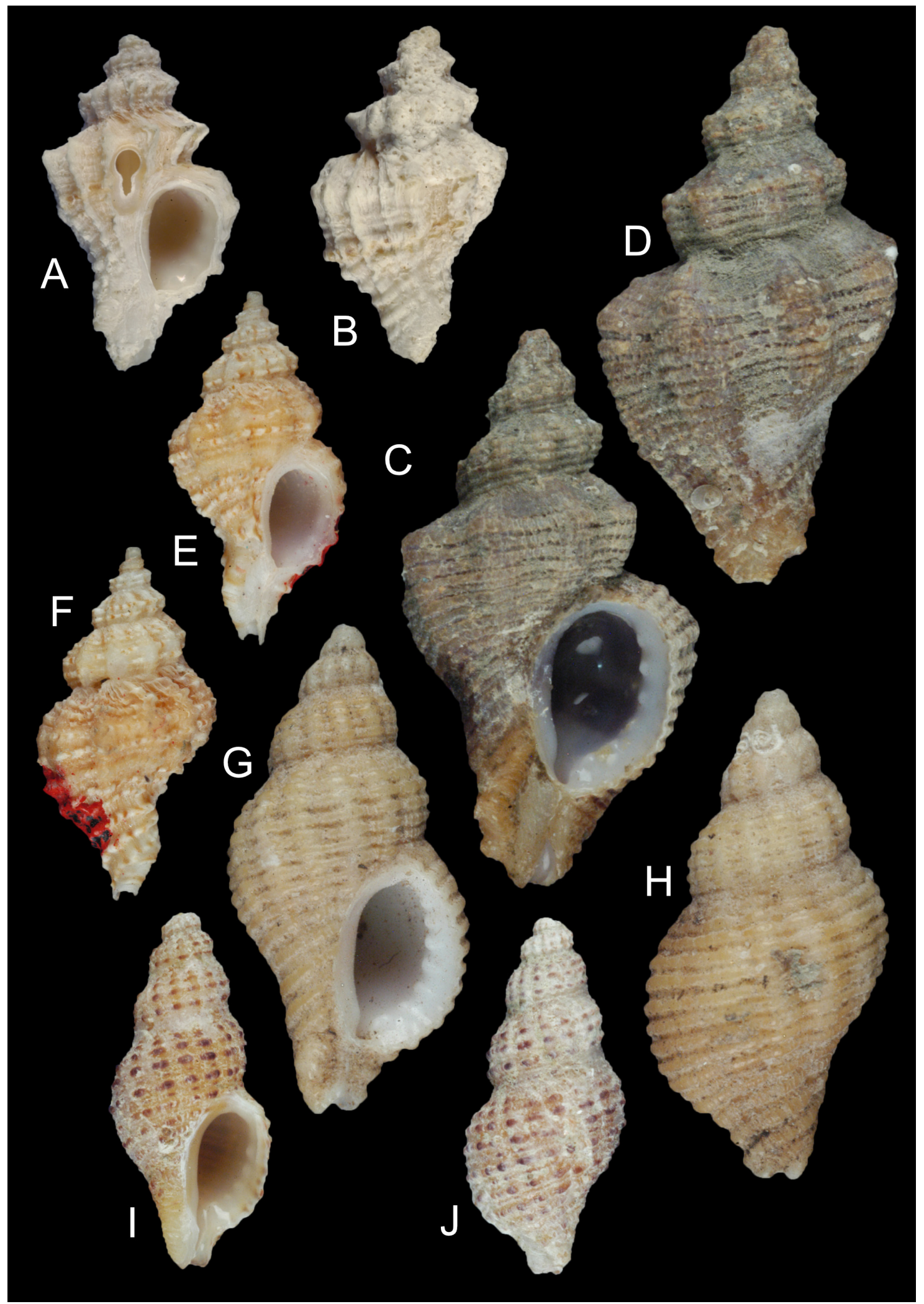

FIGURE 22. A-B. Paciocinebrina macleani n. sp., Caleta Melpomeme, Guadalupe Island, Baja California, $28^{\circ} 52.13^{\prime} \mathrm{N}, 118^{\circ}$ 15.98' W, at 92 m, holotype LACM 3049, $11.2 \mathrm{~mm}$. C-D. Paciocinebrina foveolata (Hinds, 1844), Cabrillo Beach, Los Angeles County, California, 33 $42^{\prime} 16.6^{\prime \prime} \mathrm{N}, 118^{\circ} 15^{\prime} 50.1^{\prime \prime} \mathrm{W}$, on rocks at $-0.52 \mathrm{~m}$ low tide, hypotype NHMUK $2017344,18.5$ mm. E-F. Paciocinebrina seftoni (Chace, 1958), Caleta Melpomeme, Guadalupe Island, Baja California, dredged at $73.1 \mathrm{~m}$, holotype SDNHM 12955, 11.7 mm. G-H. Paciocinebrina munda (Carpenter, 1864), Monterey, Monterey County, California, holotype USNM 46708, 16.2 mm. I-J. Paciocinebrina pseudomunda n. sp. Slate Rock, Big Sur, Monterey County, California, $36^{\circ} 07.599^{\prime} \mathrm{N}, 121^{\circ} 38.992^{\prime} \mathrm{W}$, on rocky reef at $19.5 \mathrm{~m}$, holotype LACM 3498, $11.8 \mathrm{~mm}$. 


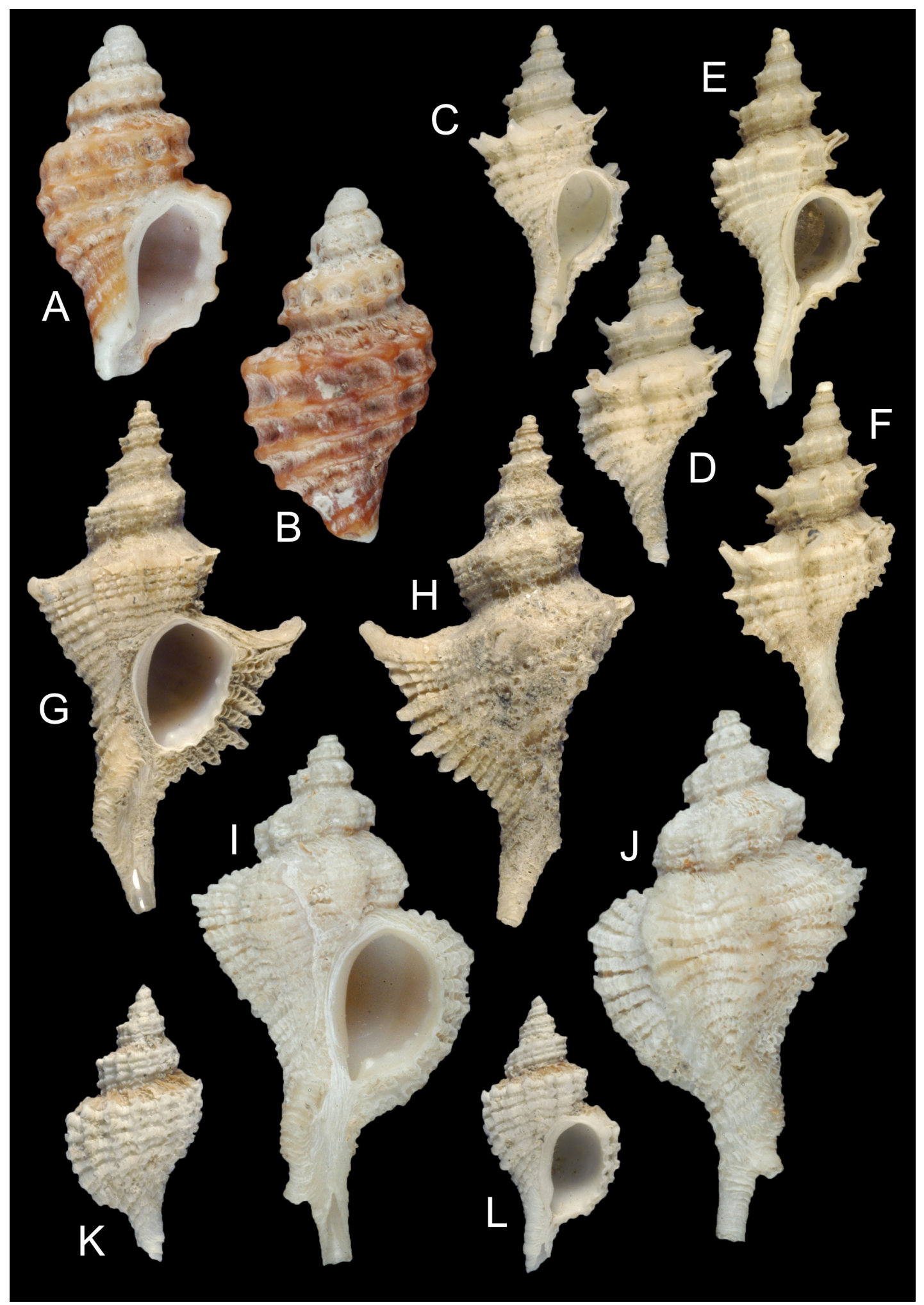

FIGURE 23. A-B. Paciocinebrina atropurpurea (Carpenter, 1865). Neah Bay, Clallam County, Washington, $48^{\circ} 22^{\prime} 40^{\prime \prime} \mathrm{N}$, $124^{\circ} 36^{\prime}$ 52" W, holotype USNM 15528B, $13.7 \mathrm{~mm}$. C-F. Paciocinebrina benitoensis $\mathbf{n} . \mathbf{s p}$. C-D. South of San Benito Island, Baja California, 28 $12.1^{\prime} \mathrm{N}, 115^{\circ} 33.3^{\prime} \mathrm{W}, 168-174 \mathrm{~m}$, LACM 1939-158.6, $12.8 \mathrm{~mm}$. E-F. $8.8 \mathrm{~km}$ south of San Benito Island, Baja California, $28^{\circ} 13.2^{\prime} \mathrm{N}, 115^{\circ} 33.4^{\prime} \mathrm{W}, 126-144 \mathrm{~m}$, holotype LACM 3082, $14.7 \mathrm{~mm}$. G-H. Paciocinebrina neobarbarensis n. sp. $3.2 \mathrm{~km}$ southeast of Long Point, Santa Catalina Island, Los Angeles County, California, $33^{\circ} 22.0^{\prime} \mathrm{N}, 118^{\circ} 30.3^{\prime} \mathrm{W}, 86 \mathrm{~m}$, holotype LACM 3497, 19.9 mm. I-J. Paciocinebrina crispatissima (Berry, 1953). Off Isthmus Cove, Santa Catalina Island, Los Angeles County, California, R/V ZACA, $60.3 \mathrm{~m}$, holotype CASIZ 064468, $20.6 \mathrm{~mm}$. K-L. Paciocinebrina thelmacrowae n. sp. Todos Santos Island, near Ensenada, Baja California, $31^{\circ} 50^{\prime} \mathrm{N}, 116^{\circ} 45^{\prime} \mathrm{W}$, at $18-45 \mathrm{~m}$, holotype LACM $2712,10.7$ $\mathrm{mm}$. 


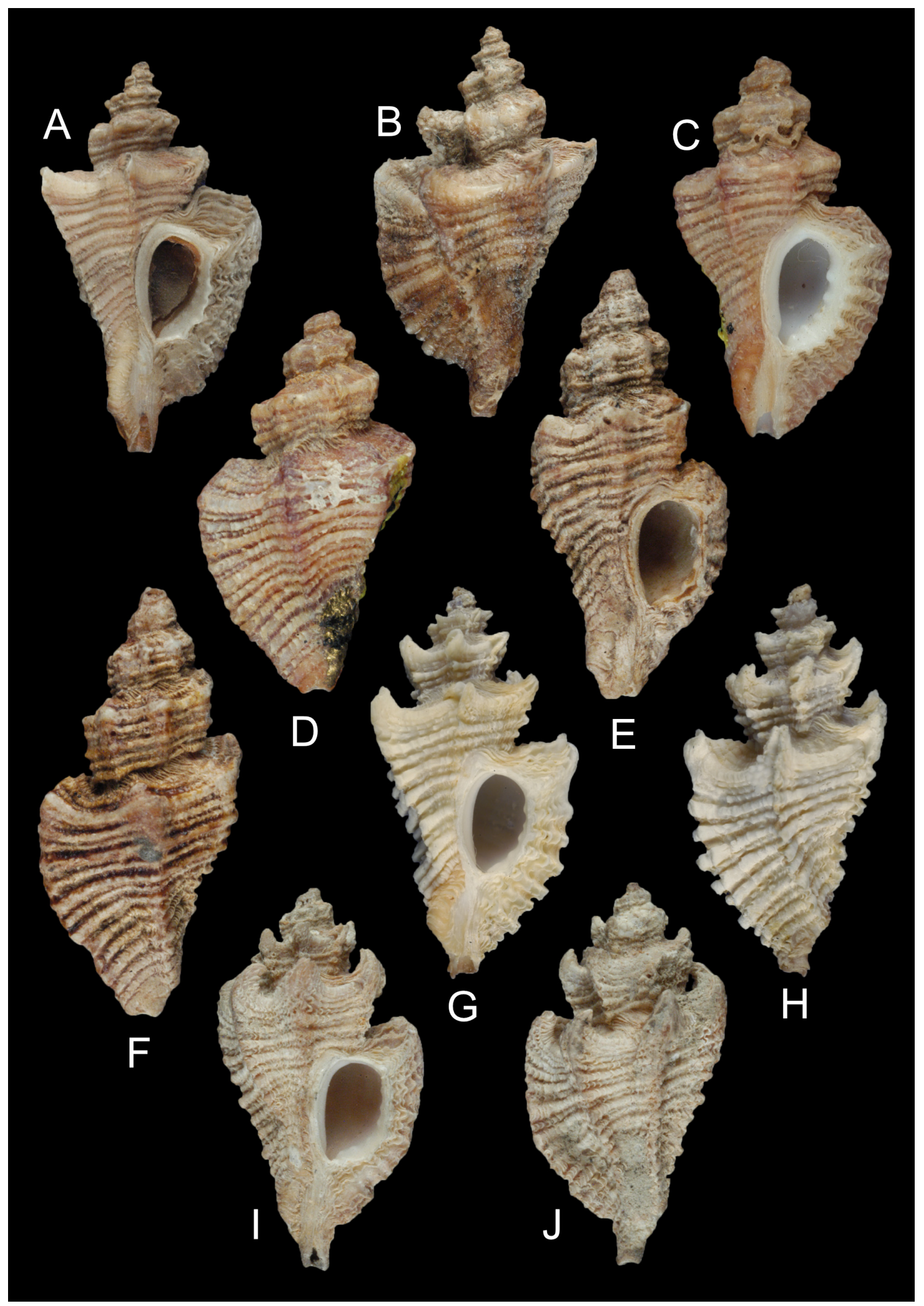

FIGURE 24. A-J. Paciocinebrina barbarensis (Gabb, 1865). A-B. Santa Catalina Island, Los Angeles County, California, $73.1 \mathrm{~m}$, lectotype of Murex (Muricidea) barbarensis Gabb, 1865, UCMP 10611, $19.2 \mathrm{~mm}$. C-D. White's Point, San Pedro, Los Angeles County, California, holotype of Ocenebra keenae Bormann, 1946, CASIZ 064477, 18.8 mm. E-F. Monterey Bay, Monterey County, California, holotype of Tritonalia interfossa var. beta Dall, 1919, USNM 46728, $21.1 \mathrm{~mm}$. G-H. Point Conception, Santa Barbara County, California, on bed rock at 21 m, LACM 11397, 19.3 mm. I-J. Point Pinos, Pacific Grove, Monterey County, California, USNM 535946, $18.8 \mathrm{~mm}$. 


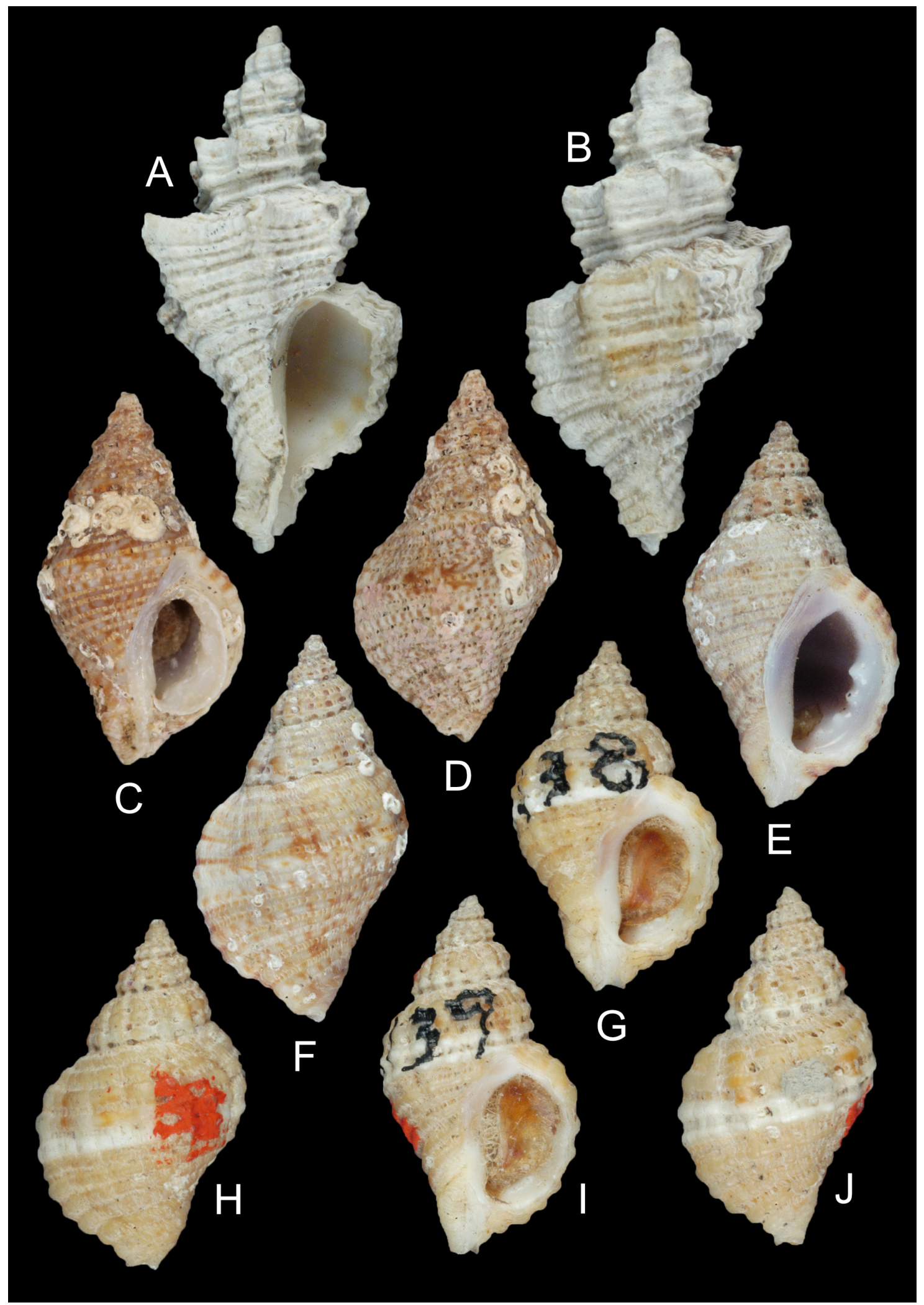

FIGURE 25. A-B. Paciocinebrina fraseri (Oldroyd, 1920). Brandon Island, Departure Bay, Vancouver Island, British Columbia, Canada, holotype CASIZ 064275, 18.8 mm. C-J. Paciocinebrina gracillima (Stearns, 1871). C-D. San Diego, San Diego County, California, at $18.2 \mathrm{~m}$, syntype of Ocinebra gracillima Stearns, 1871, USNM 46920, $13.3 \mathrm{~mm}$. E-F. Laguna Beach, Orange County, California, holotype of Tritonalia gracillima var. obesa Dall, 1919, USNM 228722, $13.8 \mathrm{~mm}$. G-H. Monterey Bay, Monterey County, California, syntype of Ocinebra stearnsi Hemphill, 1911, CASIZ 058824, 12.5 mm. I-J. Monterey Bay, Monterey County, California, syntype of Ocinebra stearnsi Hemphill, 1911, CASIZ 223328, 12.8 mm. 
Description. Shell extremely small for genus, length $10.7 \mathrm{~mm}$, width $5.5 \mathrm{~mm}$ (holotype), elongate, rhomboid in shape, spire tall, acute, shoulder tabulate, sculpture clathrate, cords strong, suture impressed, final whorl inflated, rotund, siphonal canal narrow, long. Color white, subsutural ramp orangish-brown, darker near suture. Protoconch worn, broken, teleoconch whorl profile rotund, cords thick, robust, tightly spaced, overriding ribs, slightly projecting at periphery, sculpture highly scabrous, subsutural ramp tabulate, slightly angulate, final whorl inflated. Spiral sculpture of robust cords, highly scabrous, especially at intersection of ribs. First whorl with IP, P1, P2, second with IP, P1, P2, starting s1, third with IP, P1, s1, P2, starting s2, fourth whorl with IP, P1, s1, P2, s2, starting adis; final whorl with adis, t, IP, abis, P1, s1, P2, s2, P3, s3, P4, s4, P5, P6, ADP, MP. Primary, secondary cords large, mostly of equal size, interspaces moderately wide, weakly scabrous. Denticles obsolete except weak D4. Aperture ovately broad, large sized, perimeter thick on posterior end, thinning, sharp on outer anterior region, one extremely faint denticle near anterior end of aperture.

Remarks. Paciocinebrina thelmacrowae slightly resembles three other species but is extremely small at maturity with a unique sculpture and coloration. The sculpture of $P$. atropurpurea (Figs 7G, 8A, 23A-B) is highly clathrate, has deep pits, has a similar overall squat shape, a small, restricted aperture, a brown coloration with $P$. thelmacrowae having adis, $\mathrm{t}$ thereafter, abis, s1, s2, s3, s4 (Fig. 7I) and only a faint D4 (Fig. 8C). Paciocinebrina barbarensis (Figs 9G-I, 10A-C, 24A-J) is much larger, with heavily projecting spines at periphery of the last whorl, the cords are much less defined, narrow in shape, the sutures are more dramatically indented with $P$. thelmacrowae having $\mathrm{t}$ after adis, s4, lacking $\mathrm{t}$ before and after $\mathrm{s} 1$, with $\mathrm{s} 5$, ABP (Fig. 8C) and D1-D3 (Fig. 7I). Paciocinebrina crispatissima (Figs 8E, H, 23I-J) is much larger, with more widely spaced ribs, cords thinner, less pronounced, subsutural ramp broader in expanse with $\mathrm{t}$ before adis, unlike after in P. thelmacrowae, with t after P1, P3 and s3, with ads, ABP (Fig. 8H) and D5-D6 (Fig. 8E). Spiral morphology, size at maturity and number of whorls present, prevent the misidentification of this species to juvenile specimens of other taxa.

Etymology. Named after Thelma Crow, who collected the holotype specimen here described.

\section{Acknowledgements}

We would like to acknowledge Andrea Barco (GEOMAR, Helmholtz Centre for Ocean Research, Düsternbrooker Weg 20, 24105 Kiel, Germany) and Marco Oliverio (Dipartimento di Biologia e Biotecnologie "Charles Darwin", La Sapienza University, Viale dell'Università 32, I-00185 Roma, Italy) for useful comments about the new genus Paciocinebrina as opposed to the European Ocenebrinae. Erica Clites (UCMP) allowed access to essential collection material. Terry Gosliner, Christina Piotrowski and Liz Kools (CASIZ) arranged the loan and digital images of specimens. Yuri Kantor (A. N. Severtsov Institute of Ecology and Evolution, Russian Academy of Sciences, Moscow, Russia) and Anders Warén (Natural History Museum, Stockholm, Sweden) prepared radulae and executed SEM work, Peter Marko, University of Hawaii, Honolulu, U.S.A., for his comments and suggestions about Nucella species. Greg Rouse and Harim Cha (SIO) arranged the loan of specimens. Andreia Salvador (NHMUK) was specifically helpful in assisting with the search for the holotype of Murex foveolatus and the syntypes of Vitularia aspera. Harry Taylor (NHMUK Photographic Unit) was instrumental in providing images of Vitularia aspera. Yves Samyn (IRSNB) collaborated in many useful ways. Boris Sirenko (ZIN) located and photographed the syntypes of Tritonium luridum and provided digital images of holotypes housed in his institution. Dave Strauss (UCMP) graciously photographed images of $P$. barbarensis paralectotypes, both of which aided in understanding the identity of these forms. Alex Sysoev (ZMMSU) provided the digital images of holotypes housed in his institution.

Finally, our deepest gratitude to Ellen Strong (USNM), who granted permission to access and photograph type material at the USNM. We thank her also for digital images of holotypes housed in USNM.

We additionally thank the editorial team, Lindsey T. Groves and Jann Vendetti (LACM) and Daniel Geiger (Santa Barbara Museum of Natural History).

\section{References}

Abbott, R.T. (1974) American Seashells: Marine Mollusca of the Atlantic and Pacific Coasts of North America, Second 
Edition. Van Nostrand Reinhold Company, New York, New York, 663 pp.

Abbott, D.P. \& Haderlie, E.C. (1980) Prosobranchia, marine snails. In: Morris, R.H., Abbott, D.P. \& Haderlie, E.C. (eds.), Intertidal invertebrates of California, Stanford University Press, Stanford, California, 690 pp.

Amano, K. \& Vermeij, G.J. (1998) Origin and biogeographic history of Ceratostoma (Gastropoda: Muricidae). Venus, 57, 209223.

Baird, W. (1863) Descriptions of some new species of shells collected at Vancouver Island and in British Columbia by J. K. Lord, Esq. naturalist to the British North American Boundary Commission in the years 1858-1862. Proceedings of the Zoological Society of London, for 1863, 66-70.

Barco, A., Claremont, M., Reid, D.G., Houart, R., Bouchet, P., Williams, S.T., Cruaud, C., Croulx, A. \& Oliverio, M. (2010) A molecular phylogenetic framework for the Muricidae, a diverse family of carnivorous gastropods. Molecular Phylogenetics and Evolution, 56, 1025-1039. https://doi.org/10.1016/j.ympev.2010.03.008

Barco, A., Herbert, G., Houart, R., Fassio, G. \& Oliverio, M. (2017) A molecular phylogenetic framework for the subfamily Ocenebrinae (Gastropoda, Muricidae). Zoologica Scripta, 46, 322-335. https://doi.org/10.1111/zsc. 12219

Barco, A., Marshall, B., Houart, R. \& Oliverio, M. (2015) Molecular phylogenetics of Haustrinae and Pagodulinae (Neogastropoda: Muricidae) with a focus on New Zealand species. Journal of Molluscan Studies, 81, 476-488. https://doi.org/10.1093/mollus/eyv020

Barco, A., Schiaparelli, S., Houart, R. \& Oliverio, M. (2012) Cenozoic evolution of Muricidae (Mollusca, Neogastropoda) in the Southern Ocean, with the description of a new subfamily. Zoologica Scripta, 41, 596-616. https://doi.org/10.1111/j.1463-6409.2012.00554.x

Bertsch, H. \& Rosas, L.E.A. (2016) Marine invertebrates of northwest Mexico. Universidad Autónoma de Baja California, Ensenada, Baja California, 432 pp.

Bormann, M. (1946) A survey of some West American Ocenebras, with the description of a new species. The Nautilus, 60, 3743.

Bouchet, P. \& Kantor, Yu.I. (2004) New Caledonia: the major center of biodiversity for volutomitrid mollusks (Mollusca: Neogastropoda: Volutomitridae). Systematics and Biodiversity, 1, 467-502. https://doi.org/10.1017/S1477200003001282

Buck, L. (1989) San Diego Shell Club members dive San Miguel and Santa Rosa Islands. The Festivus, 21, 98-100.

Burch, J.Q. (1945) Distributional list of the west American marine mollusks from San Diego, California to the Polar Sea. Proceedings of the Conchological Club of Southern California, Minutes of the Conchological Club of Southern California, $51,1-69$.

Claremont, M., Vermeij, G.J., Williams, S.T. \& Reid, D.G. (2013) Global phylogeny and new classification of the Rapaninae (Gastropoda: Muricidae), dominant molluscan predators on tropical rocky shroes. Molecular Phylogenetics and Evolution, 66, 91-102. https://doi.org/10.1016/j.ympev.2012.09.014

Clark, B.L. (1918) The San Lorenzo Series of middle California: a stratigraphic and paleontologic study of the San Lorenzo Oligocene Series of the general region of Mount Diablo, California. University of California Publications, Bulletin of the Department of Geology, 11, 45-234.

Collins, T., Frazer K., Palmer A.R., Vermeij, G.J. \& Brown, W.M. (1996) Evolutionary history of northern hemisphere Nucella (Gastropoda: Muricacea): Molecular, morphological, ecological and paleontological evidence. Evolution, 50, $2287-2304$. https://doi.org/10.2307/2410698

Cox, L.N., Zaslavskaya, N.I. \& Marko, P.B. (2014) Phylogeography and trans-Pacific divergence of the rocky shore gastropod Nucella lima. Journal of Biogeography, 41, 615-627.

https://doi.org/10.1111/jbi.12217

Crocetta, F., Bonomolo, G., Albano, P.G., Barco, A., Houart, R. \& Oliverio, M. (2012) The status of the northeastern Atlantic and Mediterranean small mussel drills of the Ocinebrina aciculate complex (Mollusca: Gastropoda: Muricidae), with the description of a new species. Scientia Marina, 76, 177-189.

https://doi.org/10.3989/scimar.03395.02A

Dall, W.H. (1891) Scientific results of explorations by the U.S. Fish Commission steamer "Albatross" XX. On some new or interesting West American shells obtained from the dredgings of the U.S. Fish Commission steamer "Albatross" in 1888, and from other sources. Proceeding of the United States National Museum, 14, 173-191.

https://doi.org/10.5479/si.00963801.14-849.173

Dall, W.H. (1902) Illustrations and descriptions of new, unfigured, or imperfectly known shells, chiefly American, in the U. S. National Museum. Proceedings of the United States National Museum, 24, 499-566. https://doi.org/10.5479/si.00963801.24-1264.499 
Dall, W.H. (1907) Descriptions of new species of shells, chiefly Buccinidae, from the dredgings of the U. S. S. Albatross during 1906, in the northwestern Pacific, Bering, Okhotsk, and Japanese seas. Smithsonian Miscellaneous Collections, 50, 139173.

Dall, W.H. (1919a) Descriptions of new species of Mollusca from the North Pacific Ocean in the collection of the United States National Museum. Proceedings of the United States National Museum, 56 (2295), 293-371. https://doi.org/10.5479/si.00963801.56-2295.293

Dall, W.H. (1919b) New shells from the northwest coast. Proceedings of the Biological Society of Washington, 32, $249-252$.

Dall, W.H. (1921) Summary of the marine shellbearing mollusks of the northwest coast of America, from San Diego, California, to the Polar Sea, mostly contained in the collection of the United States National Museum, with illustrations of hitherto unfigured species. United States National Museum Bulletin, 112, 1-217. https://doi.org/10.5962/bhl.title.114713

Dall, W.H. (1925) Illustrations of unfigured types of shells in the collection of the U.S. National Museum. Proceedings of the U.S. National Museum, 66 (2554), 1-41, pls. 1-36.

Deas, W. (1971) Seashells of Australia. Rigby Ltd., Adelaide, Australia, 32 pp.

Devries, T. (2003) Acanthina Fischer von Waldheim, 1807 (Gastropoda: Muricidae), an ocenebrine genus endemic to South America. The Veliger, 46, 332-350.

Egorov, R.V. (1992) Two new species of Boreotrophon (Gastropoda: Muricidae). Ruthenica, 2, 164-166.

Egorov, R.V. (1993) Trophoninae (Muricidae) of Russian and adjacent waters. Ruthenica, Suppl. 1, 1-48.

Egorov, R.V. (1994) New data on the taxonomy of molluscs of the family Trophoninae (Gastropoda, Muricidae) from the northwestern Pacific. Ruthenica, 4, 97-101.

Fair, R.H. (1976) The Murex Book: an Illustrated Catalogue of Recent Muricidae (Muricinae, Muricopsinae, Ocenebrinae). Sturgis Printing Co., Honolulu, Hawai‘i, 138 pp., 23 pls.

Fischer, P. (1880) Manuel de Conchyliologie et de Paléontologie Conchyliologique, Part 7. Savy, Paris, pp. 609-688.

Fischer P. (1880-1887). Manuel de Conchyliologie et de Paléontologie Conchyliologique. Paris, Savy pp. XXIV $+1369+\mathrm{pl}$. 23. Fasc. 1: pp. 1-112 [21. 9. 1880]. Fasc. 2: pp. 113-192 [16. 3. 1881]. Fasc. 3: pp. 193-304 [28. 7. 1881]. Fasc. 4: pp. 305-416 [5. 5. 1882]. Fasc. 5: pp. 417-512 [21. 2. 1883]. Fasc. 6: pp. 513-608 [20. 12. 1883]. Fasc. 7: pp. 609-688 [30. 6. 1884]. Fasc. 8: pp. 689-784 [29. 1. 1885]. Fasc. 9: pp. 785-896 [31. 8. 1885]. Fasc. 10: pp. 897-1008 [30. 4. 1886]. Fasc. 11: pp. 1009-1369 [15.6. 1887].

Forester, A.J. (1979) The association between the sponge, Halichondria panacea (Pallas) and the scallop Chlamys varia (L.): a commensal protective mutualism. Journal of Experimental Marine Biology and Ecology, 36, 1-10. https://doi.org/10.1016/0022-0981(79)90096-0

Gabb, W.M. (1865) Description of new species of marine shells from the coast of California. Proceedings of the California Academy of Sciences, 3, 182-190.

Gmelin, J.F. (1791) Systema Naturae per Regna Tria Naturae, Vol 13. Lipsiae, pp. 3021-3910.

Gordillo, S. \& Nielsen, S.N. (2013) The Australasian muricid gastropod Lepsiella as Pleistocene visitor to southernmost South America. Acta Palaeontologica Polonica, 58, 777-783.

Goto, Y. \& Poppe, G.T. (1996) A listing of living Mollusca 2. L'Informatore Piceno, Anacona, Italy, 520 pp.

Habe, T. \& Ito, K. (1965) Shells of the World in Colour. Vol. 1. The Northern Pacific. Osaka, Hoikusha, 176 pp.

Hemphill, H. (1911) Descriptions of some varieties of shells, with short notes on the geographical range and means of distribution of land shells. Transactions of the San Diego Society of Natural History, 1, 85-112.

Hickman, C.S. (1980) Paleogene marine gastropods of the Keasey Formation in Oregon. Bulletins of American Paleontology, $78,1-112$.

Hinds, R.B. (1844a) Descriptions of new species of Scalaria and Murex, from the collection of Sir Edward Belcher, C. B. Proceedings of the Zoological Society of London, for 1843, 124-129.

Hinds, R.B. (1844b) The Zoology of the Voyage of H. M. S. Sulphur, Under the Command of Captain Sir Edward Belcher, R.N., C.B., F.R.G.S., ETC. During the Years 1836-42. Smith, Elder and Co., London, England, 72 pp., 21 pls.

Houart, R. (2001) A review of the Recent Mediterranean and Northeastern Atlantic Species of Muricidae. Evolver, Rome, 227 pp.

Houart, R. (2011) Ocenebra, Pteropurpura, and Ocinebrellus (Gastropoda: Muricidae: Ocenebrinae) in the northwestern Pacific. American Conchologist, 39(4), 12-22.

Houart, R. \& Moffitt, R. (2010) A new Scabrotrophon (Gastropoda: Muricidae) from Hawaii and discussion about the generic classification of Boreotrophon kamchatkanus Dall, 1902, a related species. The Nautilus, 124, 112-116.

Houart, R. \& Sirenko, B.I. (2003) Review of the recent species of Ocenebra Gray, 1847 and Ocinebrellus Jousseaume, 1880 in the Northwestern Pacific. Ruthenica, 13, 53-74.

Kantor, Yu.I. \& Sysoev, A.V. (2006) Marine and Brackish Water Gastropods of Russia and Adjacent Countries: and Illustrated Catalogue. KMK Scientific Press Ltd, Moscow, 371 pp., 140 pls. 
Keen, A.M. (1937) An abridged check list and bibliography of West North American marine Mollusca. Stanford University Press, Stanford, California, $84 \mathrm{pp}$.

Keen, A.M. (1966) West American mollusk types at the British Museum (Natural History): T. A. Conrad and the Nuttall collection. The Veliger, 8, 167-172.

Kool, S.P. (1993a) Phylogenetic analysis of the Rapaninae (Neogatropoda: Muricidae). Malacologia, 35, 155-259.

Kool, S.P. (1993b) The systematic position of the genus Nucella (Prosobranchia: Muricidae: Ocenebrinae). The Nautilus, 107, 43-57.

Kool, S.P. \& Boss, K.J. (1992) Nucella Röding, 1798 (Gastropoda: Muricidae): type species. The Nautilus, 106, 21-23.

Kuroda, T., Habe, T. \& Oyama, K. (1971) The Sea Shells of Sagami Bay. Maruzen, Tokyo: xix, 741 pp. (Japanese text), 489 pp. (English text), $51 \mathrm{pp}$. (index).

Marko, P.B. \& Vermeij, G.J. (1999) Molecular phylogenetics and the evolution of labral spines among eastern Pacific Ocenebrine gastropods. Molecular Phylogenetics and Evolution, 13, 275-288. https://doi.org/10.1006/mpev.1999.0655

Marko, P.B, Moran, A.L, Kolotuchina, N.K. \& Zaslavskaya, N.I. (2014) Phylogenetics of the gastropod genus Nucella (Neogastropoda: Muricidae): species identities, timing of diversification and correlated patterns of life-history evolution. Journal of Molluscan Studies, 80, 341-353. https://doi.org/10.1093/mollus/eyu024

McConnaughey, B.H. \& McConnaughey, E. (1985) The Audubon Society nature guides, the Pacific coast, a comprehensive field guide, fully illustrated with color photographs, to the birds, plants, seashore creatures, fishes, whales, and other natural wonders of North America's western shore, from Alaska to southern California. Alfred A. Knopf, New York New York, $633 \mathrm{pp}$.

McLean, J.H. (1978) Marine shells of southern California, revised edition. Natural History Museum of Los Angeles County Science Series, 24, 1-104.

McLean, J.H. (1996) The Gastropoda, the Prosobranchia. In: Valentich-Scott, P. \& Blake, J.A. (eds), Taxonomic Atlas of the Benthic Fauna of the Santa Maria Basin and Western Santa Barbara Channel 9(2),. Santa Barbara Museum of Natural History, Santa Barbara, pp. 1-160.

McLean, J.H. (2007) Gastropoda. Shelled Gastropoda. In: Carlton, J. T. (ed.), Light and Smith's Manual: Intertidal Invertebrates from Central California to Oregon, Revised and Expanded $4^{\text {th }}$ Edition, Univeristy of California Press, Berkeley California, pp. 713-753.

Merle, D. (2001) The spiral cords and the internal denticles of the outer lip in the Muricidae: terminology and methodological comments. Novapex, 2, 69-91.

Merle, D. (2005) The spiral cords of the Muricidae (Gastropoda, Neogastropoda): importance of ontogenetic and topological correspondences for delineating structural homologies. Lethaia, 38, 367-379. https://doi.org/10.1080/00241160500355129

Merle, D., Garrigues, B. \& Pointer, J.-P. (2011) Fossil and recent Muricidae of the world, part Muricinae. Conchbooks, Hackenheim, Germany, 648 pp.

Middendorff, A.T. (1848) Vorläufige Anzeige einiger neuer Konchylien aus den Geschlechten: Litorina, Tritonium, Bullia, Natica, und Margarita. Bulletin de l'Académie Impériale des Sciences de Saint Pétersbourg, Phys.-Math. 2, $242-246$.

MolluscaBase (2018) World register of marine species. (http://www.marinespecies.org)

Myers, B.W. \& D'Attilio, A. (1986) Comments on the protoconch in the Muricidae with illustrations. The Festivus, 18, $55-77$. Oldroyd, I.S. (1924) Marine shells of Puget Sound and vicinity. Publications of the Puget Sound Biological Station, 4, 1-272.

Oldroyd, I.S. (1927) The marine shells of the West Coast of North America 2(2). Stanford University Publications, Geological Sciences, 2, 301-602.

Palmer, A.R. (1988) Feeding biology of Ocenebra lurida (Prosobranchia: Muricacea): diet, predator-prey size relations, and attack behavior. The Veliger, 31, 192-203.

Radwin, G.E. \& D'Attilio, A. (1976) Murex Shells of the World: an Illustrated Guide to the Muricidae. Stanford University Press, Stanford, California, $284 \mathrm{pp}$.

Rice, T. (1971) Marine Shells of the Pacific Northwest. Ellison Industries, Inc., Washington, 102 pp.

Spight, T.M., Birkeland, C. \& Lyons, A. (1974) Life histories of large and small murexes (Prosobranchia: Muricidae) Marine Biology, 24, 229-242.

https://doi.org/10.1007/BF00391898

Stearns, R.E.C. (1871) Preliminary descriptions of new species from the west coast of America. Conchological Memoranda, 6, 1.

Sysoev, A.V. (1992) A new hadal species of Boreotrophon (Gastropoda: Muricidae) from northwestern Pacific. Ruthenica, 2 , $166-167$.

Talmadge, R.R. (1975) A note on Ocenebra lurida (Middedorff, 1848). The Veliger, 17, 414. 
Tiba, R. \& Kosuge, S. (1985) North Pacific shells (15) Genus Trophon Montfort (s.1.). Occasional Publication of the Institute of Malacology, Tokyo, 15, 1-36.

Tsuchiya, K. (2000) Muricidae. In: Okutani, T. (ed.), Marine Mollusks in Japan, Tokai University Press, Tokyo, pp. $364-421$.

Tsuchiya, K. (2017) Muricidae. In: Okutani, T. (ed.), Marine Mollusks in Japan, 2nd edition, Tokai University Press, Tokyo, I. Atlas, 1-711; II. Text, 715-1375.

Turgeon, D.D., Quinn, J.F., Bogan, A.E., Coan, E.V., Hochberg, F.G., Lyons, W.G., Mikkelsen, P.M., Neves, R.J., Roper, C.F.E., Rosenberg, G., Roth, B., Scheltema, A., Thompson, F.G., Vecchione, M. \& Williams, J.D. (1998) Common and scientific names of aquatic invertebrates from the United States and Canada: Mollusks, $2^{\text {nd }}$ edition. American Fisheries Society Special Publication, 26, 1-536.

Vance, R.R. (1978) A mutualistic interaction between a sessile marine clam and its epibionts. Ecology, 59, 679-685. https://doi.org/10.2307/1938770

Vermeij, G.J. (2001) Innovation and evolution at the edge: origins and fates of gastropods with labral tooth. Biological Journal of the Linnean Society, 72, 461-508. https://doi.org/10.1111/j.1095-8312.2001.tb01333.x

Vermeij, G.J. (2007) The ecology of invasion: acquisition and loss of the siphonal canal in gastropods. Paleobiology, 33, 469493. https://doi.org/10.1017/S0094837300026403

Vermeij, G.J \& Vokes, E.H. (1997) Cenozoic Muricidae of the Western Atlantic region. Part XII - The subfamily Ocenebrinae (in part). Tulane Studies in Geology and Paleontology, 29, 69-118.

Vokes, E.H. (1964) Supraspecific groups in the subfamilies Muricinae and Tritonaliinae (Gastropoda: Muricidae). Malacologia, 2, 1-41.

Vokes, E.H. (1971) The geologic history of the Muricinae and Ocenebrinae. Echo, 4, 37-54.

Wicksten, M.K. (1981) Sponges and Murex: a mutualistic relationship. Of Sea and Shore, 12, 59-60. 